\title{
Arbor
}

\section{La época de Santiago Ramón y Cajal}

\section{Pedro García Barreno y Juan Fernández Santarén}

Arbor CLXXIX, 705 (Septiembre 2004), 13-110 pp.

\section{Las Ciencias de la Vida en la Transición Secular}

\section{A. Introducción: Los filósofos de la naturaleza}

En el desarrollo de las ciencias naturales, el siglo XVIII mostró, entre otras características, el intento de levantar el inventario del reino de los seres vivos. Pero es claro que la actividad de clasificar y sistematizar equivale a una descripción analítica de la naturaleza y presupone un prolijo y paciente estudio de datos y de hechos; de ahí que no sorprenda que la abrumadora cantidad de detalles predispusiera a los investigadores a descuidar un tanto la búsqueda de lo universal en la naturaleza.

Como para llenar tal laguna surgió en Alemania, hacia comienzos del siglo XIX, una escuela que hace de aquella búsqueda de lo universal su objetivo fundamental. Desafortunadamente, sus fundadores - los llamados $\mathrm{Na}$ turalphilisophen - se ilusionaron en alcanzar la meta fijada mediante especulaciones ancladas meramente en postulados apriorísticos. De ahí, que el inevitable relativismo que caracteriza a todas las proposiciones científicas, sean ellas de la Biología cómo de la Física, está ausente en las premisas y en las conclusiones de esa «Filosofía Natural», cuyos escritos parecen deducidos de una misteriosa e infalible sabiduría. Lejos del espíritu de la ciencia experimental, aquellos pensadores trataron de fundamentar un esquema de la naturaleza de tipo espiritual, acudiendo a métodos de matiz escolástico con la pretensión de descubrir la estructura del mundo natural merced a una «intuición intelectual». Aunque no lograron ningún descubrimiento, llegaron a ejercer, durtante los primeros decenios del siglo XIX, una influencia indiscutible sobre algunos investigadores eminentes. 
Apoyado en la doctrina de Kant, que había conferido al intelecto la je rarquía de legislador de la naturaleza, Friedrich Wilhelm Joseph Schelling, carente sin embargo del vigoroso criticismo de su gran predecesor, formuló su principio de la ridentidad del espiritu en nosotros y la de la naturaleza fuera de nosotros». Para él, «la naturaleza es espiritu visible, y el espíritu naturaleza invisibles. Basta, pues, sumergirse en el propio espíritu para descubrir la estructura de la naturaleza.

Pero el representante más ilustre de este movimiento, esencialmente germánico, fue sin duda Johann Wolfgang Goethe que prestigió, con su fama de gran poeta, la idea central de la «Naturalphilosophie»: la unidad del plan morfológico de todos los seres vivos. Conforme a tal idea, las categorías taxonómicas habrían sido construidas por el sumo artífice según un plan general único, del que las formas de los seres organizados materializarían distintas modificaciones. Todos los animales serían, así, meras encarnaciones del arquetipo animal único, y todas las plantas no serían sino modos diferenciados de una protoplanta.

Los planteamientos de Goethe fueron ratificados por el médico Lorenz Oken, profesor en Jena, en Munich y, por último, en Zurich. Oken, sin embargo, anticipó la teoría celular al enseñar en su escrito sobre la generación-Die Zeugung de 1805- que todos los seres vivos están formados por aglomeraciones de vesículas mucosas. También, adelantó la ley biogenética al sostener en su monumental libro de texto Lehrbuch der Naturphilosophie, de 1809, que «el animal atraviesa en el curso de su desarrollo todas las clases del reino animal, siendo el feto una representación en el tiempo de las más distintas especies animales ... Entre la evolución individual del embrión y el desarrollo del reino animal existe un perfecto paralelismo». Además, Oken fue el primero en organizar reuniones periódicas de hombres de ciencia, y lanzó la importante revista «Isis» cuya cabecera aun se conserva.

La difusión excepcional que lograron en Alemania las ideas de los $\mathrm{Na}$ turalphilosophen durante la primera mitad del siglo XIX se revela en el número de adeptos, entre los cuales se encuentra el clínico y precursor de la teoría microbiana Lucas Schönlein, el descubridor del electromagnetismo Christian Oersted, el gran fisiólogo Johann Müller y el químico Justus von Liebig, entre otros. Por otra parte, la repercusión se extendió también fuera de Alemania; tanto es así que uno de los más destacados naturalistas de la época, el francés Ètienne Geofroy Saint-Hilaire, defendía ideas muy semejantes a las de Oken.

Para construir un animal -mantenía Saint-Hilaire- la naturaleza sólo dispone de un número limitado de elementos orgánicos que puede 


\section{La época de Santiago Ramón y Cajal}

acortar, disminuir y hasta borrar, pero que no puede remover de sus lugares respectivos. De acuerdo con la «ley de las conexiones» los órganos conservan sus relaciones locales mutuas, cualesquiera que sean las metamorfosis que les impone el ajuste a sus nuevas funciones. Otra ley que guía las investigaciones de Hilaire es la «ley del equilibrio de los órganos», que admite que el desarrollo excesivo de un órgano es compensado por la evolución regresiva de un órgano vecino, ya que en el presupuesto fijo de la naturaleza todo gasto excesivo exige una economía equivalente. Estos dos principios- leyes de las conexiones y del equilibrio - son los que permiten a Saint-Hilaire equiparar órganos, que llamamos homólogos, no obstante de su radical diferencia en forma y en funciones. Estos dos principios también implican la convicción -ya formulada antes por el naturalista Charles Bonnet- de que la multiplicidad de las formas del reino orgánico es un producto del crecimiento desigual de elementos estructuralmente iguales.

«Le es suficiente a la naturaleza-sostiene Saint-Hilaire-cambiar algunas de las proporciones de los órganos para ajustarlos a sus nuevas funciones o para extender o para restringir sus aplicaciones). La hipótesis de un arquetipo único para el reino animal implica un origen común y sugiere que las especies han sufrido transformaciones en el curso del pasado. En una serie de memorias publicadas entre los años 1828 y 1837 , Saint-Hilaire se adhiere a la idea de un radical transformismo vinculando las formas actuales de la vida con especies desaparecidas cuyos restos Cuvier y otros paleontólogos acababan de descubrir. En una memoria presentada a la Academia de Ciencias en 1831, Saint-Hilaire decía: «Los animales que actualmente viven descienden, por una serie de ininterrumpidas generaciones, de animales perdidos del mundo antediluvianor.

Por su parte, Saint-Hilaire reconoció que las anormalidades anatómicas no son caprichos fantásticos de la naturaleza; detrás de la gran variedad de las formas monstruosas sostuvo que hay un cierto número de tipos funda mentales. Más aún, esperaba que una intervención mecánica en el desarro llo embrionario podría transformar una especie en otra; al antiguo sueño alquimista de la transmutación de los metales, se sumaba otro aún más osado, el de la transformación artificial de las formas básicas de la vida.

\section{B. La aparición de Biología}

Con todo ello, el término Biología, que alude a los procesos generales de la vida, aparece en el umbral del siglo XIX, en el año 1802, de la 


\section{Pedro García Barrero y Juan Fernández Santarén}

mano de Lamark en su obra Hydrobiologie, término -el de Biologíaacuñado simultánea e independientemente por los alemanes Treviranus y Burdach. Aunque ya antes había habido intentos de enfrentarse con problemas de este orden, puede decirse que en esta época es cuando empieza el análisis preciso y metódico de la sustancia viva y de las leyes generales de su funcionamiento; análisis que revelará la unidad fundamental de los dos reinos del mundo vivo. La idea de una Naturaleza eterna, fija para siempre, idea de la que no habían conseguido librarse ni siquiera los grandes materialistas del Siglo de las Luces, se hundirá, finalmente, en el curso del siglo XIX ante los repetidos ataques de que es objeto. El espíritu descubre en todas partes transiciones en el tiempo y conexiones en el espacio. Tras largas y difíciles luchas, desarrolladas en torno al problema de los orígenes del hombre y de la teoría de la evolución -que son los grandes temas de la Biología del XIX- el estudio de las ciencias de la Vida podrá construirse de un modo válido eliminando, finalmente, toda apelación a consideraciones extracientíficas de orden metafísico o teológico.

En el curso de su rápido desarrollo, la Biología, sin dejar de describir y clasificar el mundo vivo, atenderá más particularmente a los problemas del desarrollo y de la evolución de los seres; así se diversificará en numerosas disciplinas particulares, más o menos estrictamente delimitadas a medida que se amplían sus conocimientos y que progresan las técnicas. Pero esas diversas especializaciones, provocadas por la revelación progresiva de la complejidad de las cosas, no son más que diferentes mé todos de análisis dirigidos hacia un mismo objetivo de conjunto: el estudio de la Naturaleza.

Este prodigioso desarrollo de las ciencias de la Vida en el curso del siglo XIX se caracteriza, a la vez, por la instauración de métodos de observación y de experimentación cada vez más rigurosos; ello, por el uso de técnicas inéditas de posibilidades hasta entonces insospechadas, por la formulación de audaces teorías con diversas finalidades y por una enorme cosecha de investigaciones de detalle.

La idea de que las formas de los seres vivos están sometidas a cambio en el curso del tiempo, fue expresada por varios pensadores ya desde la antigüedad: Anaximandro de Mileto, Empedocles de Akragas o Aristoteles. Desde el Renacimiento científico, la idea de mutabilidad de las especies fue familiar a muchos pensadores: Francis Bacon en su utópica Nova Atlantis, Leibniz en su Protogaea. Al igual que Linneo, el gran naturalista francés Buffon compartió, en un principio, la creencia de la fijeza de las formas de los seres vivos, para llegar a sus años de madurez a la ad- 
misión de un transformismo limitado, aceptando que la fauna del globo está sometida a cambios, que muchas especies han degenerado o se han perfeccionado, y que las especies más frágiles han desaparecido o desaparecerán con el tiempo. Buffon subraya la influencia modeladora que a través del tiempo las circunstancias del ambiente ejercen sobre los seres vivos.

El problema del origen de las especies fue, mientras tanto, expuesto por Benot de Maillet, escritor y diplomático cuya curiosa obra Telliamed -anagrama del apellido del autor- trata de poner al día las ideas expresadas por Anaximandro más de 24 siglos antes. Maillet sostuvo que todas las transformaciones se produjeron bajo la acción de factores ambientales y que, convertidas en caracteres hereditarios, se transmitieron a los descendientes.

Con todo, si bien en las últimas décadas del siglo XVIII la idea de la transformación de las especies comenzaba a imponerse en el pensamiento biológico, aún hacía falta una teoría coherente para asegurar al concepto de evolución el derecho de ciudadanía en las ciencias de la vida. El mérito de haber realizado esta importante tarea pertenece al naturalista francés Lamarck que, al reemplazar las ideas y opiniones aisladas y diseminadas de sus precursores por una doctrina coherente, se constituye en el verdadero iniciador del transformismo y allana el camino a la magna obra de Darwin.

Jean-Baptiste-Pierre-Antoine de Monet, Chevalier de Lamarck, seminarista, artillero, contable, periodista y estudiante de medicina, se decidió, al fin, por la botánica. Su Flore française, de 1778 - contaba entonces con 34 años-, atrajo inmediatamente la atención sobre su autor. En esta obra Lamarck introduce un nuevo sistema taxonómico más sencillo que el de sus antecesores.

Lamarck ya había alcanzado la edad madura -tenía 55 años y habían pasado veinte desde la publicación de su primera obra-cuando el 11 de mayo de 1800 anunció en la clase inaugural (Discours d'ouverture de l'an $V I I I)$ su doctrina transformista, que desarrolló con mayor amplitud en su obra capital Philosophie zoologique y remachó en su monumental Histoire naturelle des animaux sans vertèbres. La teoría lamarckiana de la evolución de las especies, opuesta a las ideas tradicionales y rechazada o silenciada por el prestigioso Georges Cuvier, no encontró entre sus contemporáneos la valoración que merecía. El núcleo de la teoría transformista de Lamark establece que «en la marcha real de la naturaleza, su marcha dinámica, los organismos simples, por una lenta y progresiva transformación, engendran organismos cada vez más complejos y perfectos». 


\section{Pedro García Barrero y Juan Fernández Santarén}

Lamarck -desconociendo las experiencias en contra de la generación espontánea de Spallanzani o haciendo caso omiso de ellas- admitió la generación espontánea. Su punto de partida es una sustancia mucilaginosa que se produce por doquier. Los animales más primitivos así engendrados están desprovistos de órganos. Sin embargo, la materia lleva en sí -como propiedad intrínseca- el principio de su evolución progresiva: la energía motriz de sus fluidos internos que condiciona la formación de estructuras particulares: los órganos. De acuerdo con Lamarck, la evolución de los organismos encuentra su principal causa propulsora en la interacción entre las fuerzas generales de la naturaleza y los fluidos internos de la materia viva.

¿Cómo actúa el ambiente sobre la materia viva?. La respuesta a esta pregunta -contenida esencialmente en su Philosophie zoologique-constituye el núcleo central de la teoría de Lamarck. La influencia de los factores externos es directa tan sólo en el caso de las plantas y de los animales situados en los peldaños más bajos de la evolución, que son de naturaleza pasiva y, por tanto, totalmente bajo el dominio de los factores mesológicos. Pero no sucede lo mismo con los demás seres. La modificación de los factores externos crea nuevas necesidades que imponen al animal nuevos hábitos, tan duraderos como las necesidades que lo engendraron. La acción modeladora de las necesidades y de los hábitos efectúan una adaptación del organismo a los cambios del medio, y permiten al animal vivir en armonía con su ambiente. No son pues los órganos los que determinan los hábitos y las propiedades peculiares del animal, sino por el contrario son los hábitos y las necesidades impuestas por las circunstancias ambientales en las que vivieron sus antepasados, los que en el curso del tiempo modelaron su forma corpórea, sus órganos y sus facultades. Solamente cuando una serie de generaciones se mantiene sometida a su acción, la modificación orgánica que ella produce se convierte en una adquisición duradera y queda estampada en la especie. Lamarck admite, por tanto, la transmisión hereditaria de los caracteres somáticos adquiridos durante la vida individual. Tal es el esencial contenido de la «ley del uso y desuso» o «ley de la adaptación», el más conocido hallazgo lamarckiano.

Por su parte, Lamarck, ajeno al antropocentrismo imperante en su tiempo, extendió los alcances de su teoría al origen del hombre. Su hipótesis asigna al Homo sapiens antepasados cuadrumanos, anticipando así una importante afirmación de la escuela de Darwin. Con todo, la hipótesis de la transmisión de los caracteres somáticos adquiridos, para la que no disponía de pruebas fue vigorosamente combati- 
da por August Weismann y su escuela, cayendo en el olvido antes de la muerte de su autor.

\section{El tiempo de Ramón y Cajal}

Hasta aquí, los antecedentes. La actualidad histórica o simplemente actualidad es el lapso temporal al que todos los hombres que viven un determinado momento cronológico -las tres generaciones que en cada uno de ellos coexisten entre sí, diría Ortega- pueden llamar y con frecuencia llaman, nuestro tiempo. Teniendo en cuenta lo que el año 1848 representa en el curso de la historia general de Europa, no parece inadecuado proceder como si en esa fecha comenzase la nueva situación histórica del hombre moderno. A esa mentalidad nueva, imperante en todo el mundo culto en la segunda mitad del siglo XIX y las primeras décadas del siglo actual, corresponde el periodo de la historia al que dedicaré los próximos minutos. Corresponde, en términos generales, a los años de juventud y formación y de plenitud creadora vividos por Cajal y que si nos centramos en el periodo de su apogeo científico se refieren al momento del «positivismo naturalistor.

En pocos momentos de su historia ha alcanzado tan alto nivel como en ese el cultivo de las ciencias de la naturaleza y, en ninguno, tanto prestigio. El hombre de 1880 -D. Santiago contrae matrimonio con Dña. Silveria Fariñas y publica su primer trabajo: Investigaciones experimentales sobre la génesis inflamatoria y en especial sobre la emigración de los leucocitos. De este trabajo Cajal comenta: «... y fui arratsrado a una solución sincrética o de transición. errónea conforme suelen ser en ciencia casi todas las opciones diagonales).- el hombre de 1880 espera de la ciencia natural todo lo que puede conseguirse sobre el planeta.

Mientras la física clásica completaba su imagen del cosmos y la química llegaba a su edad adulta, la biología científica logró convertirse en disciplina central de la visión naturalista del universo. Varias fueron las causas principales de esa fantástica ascensión: un avance decisivo de la tarea de conocer la constitución morfológica elemental de un organismo vivo; la consolidación definitiva de la fisiología científica por obra de los discípulos y continuadores de Müller y de Magendie, y la aparición y el rápido prestigio universal de una teoría de la evolución biológica aparentemente basada sobre la pura observación de la realidad vegetal y animal. Con todo, no era nueva la concepción evolutiva de las formas vivientes: Erasmus Darwin, Buffon, los filósofos de la naturaleza alemanes 
y Lamark la habían afirmado, cada uno a su modo, en lo tocante a las especies zoológicas. Por su parte, el geólogo Charles Lyell se atrevió a construir la geología sobre la idea de una transformación continua de la corteza terrestre y en contra de la doctrina de las catástrofes de Cuvier, entonces imperante; y el naturalista Alfred Russell Wallace dio a conocer al propio Darwin, en 1858, una monografía significativamente titulada "Sobre las tendencias de las variedades a separarse indefinidamente del tipo original»; ensayo que contenía la idea de la evolución de las especies mediante la selección natural.

\section{a. El evolucionismo}

Pero el verdadero triunfo del evolucionismo -o del transformismo, como entonces se decía- no advino hasta 1859 , con la publicación de «El Origen de las Especies» de Charles Darwin. El uso de las palabras «evolución» y "evolucionismo» en el sentido que hoy día tienen -opuesto al que tuvieron en el siglo XVIII- fue universalmente difundido por la obra de Herbert Spencer. Participó Darwin en la expedición científica del Beagle, entre los años 1831 y 1836 , y con la experiencia en ella recogida y la que adquirió después acerca de la domesticación y la cría de de las especies animales y vegetales, maduró su famoso libro que puede resumirse, desde un punto de vista doctrinal, en las tres siguientes tesis: todas las especies vivientes proceden de la paulatina transformación de otras anteriores; esa transformación tiene su causa en la lucha de los individuos por su existencia, pues subsisten los más aptos, los mejor adaptados, y en tercer lugar, los caracteres morfológicos y fisiológicos adquiridos se transmiten hereditariamente a la descendencia. El prestigio científico y popular del darwinismo fue rápido y estruendoso.

Además, el nacimiento y el pronto vigor de la ecología biológica, ciencia de la distribución de los seres vivos en la superficie del planeta, fruto de varias expediciones científicas continuadoras de las famosas de Cook y de Brown y culminadas por la del Chellenger entre los años 1872 y 1876 - Cajal se Licencia en Medicina, gana una plaza en la Sanidad Militar, viaja a Cuba y regresa, enfermo, a España-.

Descendiente de una familia de intelectuales, Charles Robert Darwin nació en Inglaterra el 12 de febrero de 1809, año en que Lamarck publicó su Philosophie zoologique. Falleció el 18 de abril de 1882, a los 73 años. Sus restos descansan en el Panteón Británico, la Abadía de Westminster, junto a los de Isaac Newton y de William Shakespeare. Por otro lado, 


\section{La época de Santiago Ramón y Cajal}

1882 es, también, el año de la muerte de Theodor Schwann, anatómico y fisiólogo alemán; y para Cajal, el del nacimiento de su primer hijo, Santiago.

Antes de su memorable viaje alrededor del mundo, Darwin compartía la creencia, casi general de los naturalistas contemporáneos, en la fijeza de las especies y apenas abrigaba dudas acerca de la veracidad de la hipótesis creacionista bíblica. Sin embargo, tras la experiencia del Beagle Darwin concluye en su Diario de Viaje: «... parece, pues, que nos acercamos tanto en el espacio como en el tiempo al hecho fundamental, el secreto de los secretos, es decir, el problema de la aparición de nuevos seres sobre la Tierrow.

Darwin no tardó en convencerse de que, en realidad, estaba aún lejos del secreto de los secretos. Al admitir la mutabilidad de las especies sólo había dado el primer paso hacia una teoría de la evolución. Le resultó evidente -en contra a lo sostenido por Lamarck- que ni la acción del ambiente ni los esfuerzos de los seres vivos para adaptarse a las condiciones circundantes, podría explicar las transformaciones de las formas de vida. Para encontrar la causa motora de la evolución Darwin, después de su regreso a Inglaterra, empezó a acumular hechos en gran escala, en especial un material realmente imponente suministrado por la horticultura y la crianza de animales. Así, las experiencias del criador, a las que está dedicado el primer capítulo del Origen de las Especies, desempeñaron un decisivo papel en la argumentación de Darwin de la selección natural. Pero, ¿cuál es, en la naturaleza el factor capaz de reemplazar al criador?. Esta pregunta detuvo a Darwin hasta el día de octubre de 1838 en que cayó en sus manos el célebre libro de Thomas Robert Malthus. En su brillante y audaz tratado Essay on the Principles of Population de 1798, el economista inglés había dado una sombría visión del porvenir de la humanidad; había sostenido que la población del globo tiende a crecer en proporción geométrica, mientras que el abastecimiento de alimentos aumenta, a pesar de los adelantos de la agricultura, solamente en progresión aritmética. Estas ideas de la teoría de Malthus proporcionaron a Darwin la clave que buscaba. Había hallado el factor que en la naturaleza reemplaza a la intervención del criador: la lucha por la existencia -struggle for life-. El principio de estos fenómenos conexos: lucha por la existencia y selección natural, constituye el eje de la teoría de Darwin y su exposición forma el contenido esencial del Origen de las Especies.

Pero si a pesar del potencial reproductivo ninguna especie ha invadido el especio vital del planeta, si por el contrario la población absoluta y relativa de las especies permanece grosso modo constante, es porque la 
lucha por la existencia realiza una formidable destrucción de individuos jóvenes antes de que lleguen a la edad de la procreación. En medio de una naturaleza hostil, todos los seres tratan de sobrevivir. En esta tremenda y perpetua competencia ¿quién sucumbe, ¿quién logra sobrevivir?.

Darwin, en su respuesta a estas preguntas, considera que los individuos de una y la misma especie siempre se distinguen entre sí, aunque esas diferencias sean a menudo ínfimas. Entre esas características diferenciales puede haber una -o incluso varias- que proporcionan al individuo una ventaja en sus complejas relaciones con los demás seres y con las condiciones biofísicas del ambiente, ayudándolo a mantenerse en la lucha por la existencia. Los portadores de tales características ventajosas poseen, pues, mayor probabilidad se escapar a los peligros de la competencia. De este modo sobreviven los más aptos -survival of the fittest-y sólo tales privilegiados resultan los elegidos para reproducirse y propagar la especie. En cada generación se realiza de esta manera un inexorable tamizado que, a la vez, elimina a los menos aptos y robustece los caracteres favorables de los que sobreviven. Esta acción acumuladora y perfeccionadora de la selección natural constituye el mecanismo que dio origen, en el curso de las edades geológicas, a la diversidad de las formas de vida -Por su parte. Cajal manifestó que "las características anatómicas que han prevalecido y se han perpetuado hereditariamente, lo han hecho por ser provechosas, no por una idea utilitaria impuesta por un principio rector inminente o trascendente. ... no debe confundirse utilidad con finalidad ....t.

Pero los seres no sólo luchan para sobrevivir, sino también para reproducirse. Al lado de la selección natural surge en el reino animal la selección sexual como consecuencia de la brega entre los individuos del mismo sexo, generalmente los machos, por la posesión del otro sexo. Esta forma de selección es más específica y más restringida en sus alcances; su resultado no es la muerte del émulo fracasado sino la nulidad de la progenie. Sin embargo, la lucha no es menos encarnizada.

La idea de una lucha universal por la existencia -sugerida de la lectura de la obra de Malthus- pertenecía a los supuestos psicológicos y sociológicos de la victoriosa y dominadora burguesía; y la doctrina de un origen natural y científicamente explicable de las especies vivientes pareció ser una respuesta decisiva de la ciencia al Génesis. Hubo no sólo una biología, sino también, una antropología, una ética, una sociología y una historiología darwinistas; y aunque la calidad intelectual de los adversarios del transformismo fuese muy considerable -entre otros, Owen 
y su vocero el obispo de Oxford Samuel Wilberforce en Inglaterra, Virchow en Alemania, Claude Bernard en Francia o Agassiz en EE.UU-, el esfuerzo y el entusiasmo de otros de no menos calidad, como Huxley, Spencer, Haeckel o Weismann en cabeza, logró hacer del pensamiento darwiniano, en las postrimerías del siglo XIX, un credo universal. Por lo que atañe a la Biología en sentido estricto, la taxonomía, la morfología descriptiva, la anatomía comparada y la ontogénesis, fueron total o parcialmente desarrolladas desde el nuevo punto de vista.

Las variaciones que ofrecen los puntos de partida a la selección nat ural -es decir, las pequeñas diferencias ventajosas existentes entre individuos de la misma especie- las considera Darwin como hechos empíricos. Sin embargo, no por ello dejó de preguntarse cuales podrían ser sus causas. Sus especulaciones a este respecto no fueron ni muy claras ni muy profundas. Suponía que todas las variaciones, cualquiera fuera su origen, eran capaces de integrar el patrimonio hereditario; admitía, al igual que Lamarck, la trasmisibilidad de los caracteres adquiridos, y propuso una hipótesis - de la pangénesis- para dar cuenta del fenómeno de la herencia biológica, aunque se dio cuenta de la caducidad de su hipótesis. Evidentemente, la hora de la genética aún no había sonado; cuando el Origen de las Especies apareció, esta reveladora rama de la biología estaba tan sólo formándose clandestinamente en el jardín del monje Mendel.

\section{b. El nacimiento de la genética}

Los métodos y los conceptos fundamentales de la ciencia genética fueron establecidos por Francis Galton, quién aplicó la estadística matemática al estudio de la herencia; por Gregor Mendel, descubridor de las leyes que llevan su nombre, y por August Weismann, autor de la teoría del plasma germinativo y de la idea de los cromosomas como portadores de los caracteres hereditarios. Publicadas entre 1866 y 1869 -Cajal, con 14 años. se inicia, primero en dibujo y luego, en los veranos, en los estudios anatómicos-/ publicadas en esos años las «leyes de Mendel» en una revista de tercer o cuarto orden, no fueron conocidas hasta que el holandés de Vries, el alemán Correns y el austriaco von Tschermak, las recuperaron en el año de 1900 -Cajal es nombrado director del Instituto Nacional de Higiene Alfonso XII, recién fundado, y recibe el Premio Moscu, concedido en el Congreso Internacional de Medicina celebrado en París en el año anterior-. 


\section{Pedro García Barrero y Juan Fernández Santarén}

La observación diaria de la existencia de una semejanza entre los progenitores y sus descendientes pertenece, sin duda, al acervo más antiguo del saber humano. Todavía en 1872 Darwin declaraba que « ... las leyes que gobiernan la herencia son, en su mayor parte, desconocidas». Y, sin embargo, cuando el autor del Origen de las Especies escribía esta líneas en la sexta edición de su gran obra, tales preguntas que en ella formulaba ya habían sido claramente contestadas por el monje agustino Gregor Mendel, que había nacido el mismo año que Pasteur, en 1822.

Los descubrimientos de Mendel, formulados en su ley de la «dominancia y la de la segregación o disyunción de los caracteres», señalaron el punto de arranque histórico de una nueva ciencia: la genética. En 1865 - Cajal, con 13 años, estudia en el Instituto de Huesca- Mendel hizo conocer sus investigaciones en dos sesiones de la «Sociedad para el estudio de las ciencias naturales» de Brünn, publicando luego su trabajo -una obra maestra a la vez teórica y experimental- en el boletín de la misma sociedad con el título Versuche über Pflanzenhybriden. La comunicación de Mendel cayó en oídos sordos, tanto en la sesión en que se trató su trabajo como la publicación que lo recogió. Durante los 34 años siguientes no hubo persona alguna -así lo atestiguan los documentos- que comprendiera que en el marco de aquellas 40 páginas se revelaba una de las más importantes leyes naturales descubiertas por el hombre. El hecho de que el trabajo de Mendel fuera publicado en un boletín poco leído no explica el olvido en que cayeron sus investigaciones. Ese boletín mantenía intercambio con más de 120 instituciones científicas, austriacas y extranjeras; además el propio autor hizo llegar ejemplares de su memoria a varios biólogos de nombradía.

Las razones de la incomprensión fueron de otro tipo. Primero, cuando se publicó el descubrimiento poco se sabía acerca de lo que ocurría en las células reproductoras en el instante de la fecundación. Por otra parte, en ese momento el interés de los biólogos -a seis años de distancia de la gran obra de Darwin- se centraba más en los factores de evolución que modificaban las especies, que en los factores de herencia que regían su estabilidad.

Durante los años en que los descubrimientos mendelianos permanecieron desconocidos, los problemas de la herencia biológica fueron estudiados principalmente en relación con la teoría de Darwin. Galton estableció la «ley de la herencia ancestral», pero el botánico danés Wilhem Ludwig Johannsen concluyó que la selección, sea natural o artificial, no actúan sobre las líneas puras, cuya sustancia hereditaria es estable y, por tanto, las razas puras son fijas, constantes y excluyen la variabilidad. 


\section{La época de Santiago Ramón y Cajal}

En sus ultimas y rígidas consecuencias, las conclusiones de Johannsen entrañarían no sólo el derrumbe del darwinismo sino que señalarían el ocaso de la teoría de la evolución de los seres vivos. Pero únicamente tal posición sería tan trascendente si las variaciones fluctuantes fueran la única clase de variaciones o, en otros términos, si la fijeza de las líneas puras fuera absoluta. Sin embargo, el gran paladín del darwinismo, Thomas Huxley había escrito «que la naturaleza a veces hace saltos. Este hecho nos parece -continuaba Huxley-nos parece particularmente notable, ya que permite rechazar ciertas objeciones accesorias que se hicieron a la teoría de la transformación de las especiess.

\section{c. El darwinismo}

Con todo ello, el darwinismo -expresión biológica de una visión de la realidad cada vez más extendida en toda Europa desde fines del siglo XVIII- se hizo pronto una verdadera "concepción del mundo". Algo contribuyeron a ello los biólogos darwinistas como Huxley, Wallece, Hooker y otros; pero quienes más eficazmente ayudaron a convertir el «evolucionismo» darwiniano en una doctrina de alcance y resonancia universales fueron el filósofo Herbert Spencer y el naturalista Ernst Haeckel =Comenta Cajal que, en la tertuluia del Suizo, urendimos veneración y entusiasmo hacia el evolucionismo y sus pontifices, Darwin y Haeckeb)-. En una serie de obras escritas entre 1862 y 1893 Spencer construyó sobre la evolución todo un sistema filosófico que permitía dar cuenta del curso progresivo del universo. Haeckel, profesor de Zoología en la Universidad de Jena, más fogoso e imaginativo que Spencer, fue el sumo apóstol del darwinismo. En su Morfología general de los organismos, publicada en 1866 intentó forjar una síntesis del darwinismo y de la morfología idealista; más tarde compuso una serie de libros de enorme resonancia popular-Historia Natural de la Creación y Los Enigmas del Universo, entre otros-, en los que mezcló la teoría de la evolución, el monismo, el radicalismo político y la polémica antirreligiosa.

Darwin había considerado la teoría de la descendencia como una tesis que es necesario demostrar. La posición de Haeckel es totalmente distinta; Haeckel utiliza dicha teoría -que a su juicio es una verdad inque brantable- para aclarar con su ayuda todos los problemas de la biología. "Los inapreciables descubrimientos de Darwin - escribe- han iluminado el dominio de la naturaleza orgánica de tal manera que hoy no podemos considerar como inexplicable ningún hecho biológico». La morfología de 


\section{Pedro García Barrero y Juan Fernández Santarén}

Haeckel es una zoología general expuesta y explicada mediante la teoría darwiniana. "La ontogenia-sostiene Haeckel y ello es el punto central de su teoría- // la ontogenia es la rápida recapitulación de la filogenia: los estados del desarrollo que recorre el mecanismo individual desde el huevo hasta su plena evolución, es una repetición abreviada y acelerada de las transformaciones que sufrieron los antepasados del individuo en el curso de la historia de la especies.

Por otro lado, Haeckel se había propuesto fijar el lugar del hombre en la genealogía del reino zoológico; esfuerzos qu alcanzaron su culminación en el Congreso Zoológico internacional celebrado en 1898 -Cajal redacta un trabajo de «tendencias filosóficas» acerca de la organización fundamental de las vías ópticas y la probabale significación de los entrecruzamientos nerviosos; veranea en Miraflores de la Sierra, en Madrid, con Olóriz, y escribe en la prensa a favor del regeneracionismo nacional-. En su exposición, Haeckel identificó el Pithecanthropus erectus -cuyos restos fósiles habían sido encontrados mientras tanto por Dubois- con el eslabón que vincula los monos superiores con el hombre. Pese a sus errores y a su incuestionable confusión mental, Haeckel, no leído ya por casi nadie, fue un buen ejemplo del entusiasmo seudorreligioso que la ciencia de la naturaleza llegó a suscitar en los últimos decenios del siglo XIX y en los primeros lustros del s XX.

A las tres causas del auge de la biología - evolución, lucha por la supervivencia y herencia- / a estas tres causas hasta ahora mencionadas, deben añadirse otras tantas. Una viva y extensa preocupación en torno al problema del origen de la vida. Frente a los que seguían recurriendo a la idea de una inmediata intervención creadora, la mayoría admitió, con Huxley y Haeckel, la hipótesis de una aparición natural y azarosa de los primeros seres vivientes. Algunos idearon la teoría de la «panspermia», que admitía que los primeros gérmenes vivientes habrían sido transportados a la Tierra desde otros astros. Debe recordarse que la resonante polémica de Pasteur y Pouchet acerca de la generación espontánea fue parte muy importante en la discusión sobre la biogénesis.

\section{d. Los orígenes del hombre}

Otro ingrediente al auge biológico fue la paleontología. Los hallazgos y las reconstrucciones de Cuvier quedaron pronto muy rebasados por una serie de descubrimientos sensacionales: las plantas fósiles en la hulla -la célebre impronta de la Archaeopteryx lithographica- la ascendencia filo- 
genética del caballo y, por fin, la serie fósil de los animales gigantes de América.

En 1859, eminentes científicos británicos, entre ellos Charles Lyell, tras visitar el cuestionado yacimiento de Abbeville y donde se había fundado una modesta Sociedad de Emulación, el paleontólogo francés Albert Gaudry el inglés Lyell, ratificaron su convinción sobre la importancia de las excavaciones realizadas; La prueba geológica de la antigüedad del hombre fue el título de una monografía publicada por Lyell en 1863 - $\mathrm{Ca}$ jal, con 11 años, se explaya en Ayerbe-. A partir de esas fechas se produce una explosión de trabajos; Del hombre antediluviano y de sus obras, y Sobre la antigüedad geológica de la especie humana en la Europa occidental, son dos ejemplos que intentan dar al traste con las ideas del Diluvio y los cataclismos. Pensando que la historia del hombre, como la de los animales o la de la Tierra, es una obra continua, Édouard Lartet, abogado de profesión y autor de la última de las obras citadas, presentó los primeros elementos de una cronología paleontológica.

Poco después, en 1865, Fuhlrott publicó la descripción de los pocos fragmentos que habían podido salvarse (una bóveda craneal y algunos huesos largos) de un esqueleto descubierto en 1856 -la familia de Cajal, contando éste cuatro años, se traslada a Valpasmar y Cajal inicia sus estudios en la escuela del pueblo- por los obreros de una cantera situada en el barranco llamado de Neanderthal, en la Prusia renana. Aunque numerosos naturalistas vacilaron al principio, antes de atribuirlo a un hombre, no cabe duda de que pertenecen a lo que hoy se conoce como hombre de Neanderthal.

Por su parte, el ya nombrado Lartet encontró, en 1868, durante los trabajos realizados en la línea férrera de Périgueux, cinco esqueletos bajo el refugio de Cro-Magnon, cerca de Dordoña. Estos y otros hallazgos similares provocaron interminables discusiones. Tres obras tuvieron especial resonancia en tales discusiones: La Descendencia del Hombre y la Selección Respecto del Sexo, publicada por Charles Darwin en el año 1871, y la Historia Natural de la Creación y la Antropogénesis o Historia de la Evolución Humana, de Ernst Haeckel, escritos en 1868 y 1874. Recogiendo las teorías de Lamarck sobre el origen animal del hombre, Haeckel afirmaba la existencia de un intermediario morfológico entre los monos superiores y el hombre, al que dio incluso, en su hipótesis, el nombre de Pithecanthropus.

Todo ello entusiasmó a un joven médico militar holandés, Eugène Dubois, quién se dirigió a las Indias holandesas -Rudolf Virchow había sentado el principio metódico de que había que buscar los primeros hombres 


\section{Pedro García Barrero y Juan Fernández Santarén}

en el archipiélago de Sonda- con la firme intención de buscar el hipoté tico hombre-mono. Dubois comenzó por Sumatra y luego, en 1890 -Cajal estudia la neurogenia, el desarrollo embrionario del sistema nervioso. Sus trabajos son reconocidos en Alemania y Francia-, pasó a Java. Al año siguiente - en 1891 Cajal concluye el «principio de la polarización dinámicoos y gana las oposiciones a la Cátedra de Histología de Madrid-, al pie del volcán Lawu-Kukusan, en las orillas del rio Solo, Dubois encontró la bóveda craneal, un fémur y un diente de un ser intermedio entre el hombre y el mono, con una capacidad craneal estimada en $900 \mathrm{ml}$; publicó su descubrimiento en 1894 -Cajal es invitado a pronunciar la Croonian Lecture en la Royal Society de Londres, y se le otorga el grado de Doctor por Cambridge. Publica, según el propio Cajal sfanático irreductible de la religión de los hechos", su primer trabajo de tendencia teórica: "Consideraciones generales sobre la morfología de las células nerviosas», que envió al Congreso Internacional de Medicina celebrado en Roma-, y dio al ser con que se había topado el nombre de Pithecanthropus erectus, considerándolo el antepasado directo del hombre moderno, lo que supuso otro nuevo escándalo.

\section{e. El redescubrimiento de las leyes mendelianas}

Hacia fines del siglo pasado la convergencia de varios adelantos de la citología contribuyeron a conferir un renovado interés hacia los problemas de la hibridación, cuya solución se encontraba oculta en la memoria desconocida de Mendel. En esta época habían sido ya investigados los fenómenos nucleares de la fecundación, ya se habían descubierto los cromosomas y observado los admirables mecanismos que distribuyen estas configuraciones filiformes localizándolas en el núcleo de las células-hijas, y ya la idea del genial teórico Weismann, que desde 1883 -Cajal obtiene por oposición la Cátedra de Anatomía de Valencia, y publica varios artículos de popularización histológica bajo el seudónimo de Dr. Bacteriohabía entrevisto en los cromosomas la base material de la herencia, comenzaba a adquirir contornos más firmes. Tales circunstancias atrajeron la atención de muchos investigadores hacia los problemas de la herencia, y entre ellos varios atacaron ese problema -como lo hiciera Mendel- mediante el cruzamiento de plantas. No es pues sorprendente que se redescubrieran las leyes mendelianas; lo que si fue notable es que ese redescubrimiento tuvo lugar en tres países europeos por tres botánicos y casi simultáneamente. 


\section{La época de Santiago Ramón y Cajal}

No fue una casualidad tal redescubrimiento. Llegó como consecuencia de una discusión en torno a la continuidad o a la discontinuidad en la variación de los caracteres hereditarios. Frente al hipotético continuismo de Darwin se levantó, apoyada en hechos observables, la teoría de las mutaciones discontinuas de Hugo de Vries. El mecanismo cromosómico de la herencia mendeliana fue determinado por el belga van Beneden - padre de la constancia específica del número de cromosomas- $\mathrm{y}$, sobre todo, por los pacientísimos trabajos del norteamericano Thomas Hunt Morgan y su escuela, que establecieron la teoría de los genes. Son también dignos de mención el danés Johannsen, a quién se deben los conceptos de genotipo y de fenotipo, y el alemán Roux, creador de la embriología experimental y de la mecánica del desarrollo.

El primero de ellos fue el holandés Hugo de Vries, profesor de la Universidad de Amsterdam, cuya obra Die Mutationstheorie, publicada en los umbrales de nuestro siglo constituye, históricamente, el punto de arranque de la actual teoría de la evolución. Guiado por la convicción de que la variación hereditaria -contrariamente al concepto darwiniano- no es un fenómeno continuo y paulatino sino que es debida a un súbito y esporádico cambio "germinal», a una "mutación», de Vries redescubrió las leyes de la dominancia y de la segregación. Sobre las formas engendradas por tránsitos súbitos en sus células reproductoras, la selección natural ejerce luego su acción eliminando las formas no adaptadas, pero manteniéndose, por lo demás, como especies perfectamente estables entre mutaciones.

Llegaba así para Mendel, 16 años después de su muerte, la hora de la rehabilitación en una forma más completa de la que él soñara. A partir de 1900 -Cajal avanza en el estudio del cerebro humano, y asienta la doctrina de las localizaciones cerebrales-y sobre los fundamentos creados por Méndel y de Vries se ha erigido el gigantesco edificio de la genética experimental, uno de cuyos principales constructores, Thomas Hunt Morgan escribió en su Critique of the Theory of Evolution de 1916 el siguiente párrafo que ilustra la universalidad de las leyes de Mendel: «Se ha comprobado que el descubrimiento acerca de la herencia realizado por Mendel en los guisantes comunes se aplica en todas partes, tanto en el reino vegetal como en el animal sin exceptuar al hombre. Morgan obtuvo el PremioNobel de Fisiología o Medicina en el año 1933 -aparece en Archivos de Neurobiología un artículo de Cajal titulado iNeuronismo o reticularismo?- por sus descubrimientos referentes al papel desempeñado por los cromosomas en la herencia. 


\section{f. El fin del generacionismo}

Las investigaciones de Pasteur acerca de la fermentación lo llevaron, por la lógica misma de sus conclusiones, a enfrentarse con el milenario problema de la generación espontánea, antiguo legado aristotélico. Fue Rudolf Virchow quién concibió el organismo del ser vivo como una urepública celular, en la que cada célula es un ciudadanà. En esa concepción la célula no es solamente el elemento morfológico, sino también la última unidad vital de los órganos. "Todo animal -afirma Virchow-parece como una suma de unidades vivientes, cada una de las células lleva en sí misma las caracteristicas completas de la vidon. Virchow rechaza definitivamente la hipótesis de Schwann acerca de la génesis de la célula a partir de la masa amorfa del hipotético blastema, y sostiene que donde nace una célula debe haber existido otra célula, así como un animal no puede proceder sino de otro animal y una planta de otra planta. Virchow condensa esta «ley de la continuidad del desarrollo» en su célebre axioma: «Omnis cellula ex celluloor que, por una parte recuerda el clásico lema acuñado en el siglo XVII por Francesco Redi: «Omme vivum ex vivo» y, por otra parte, preludia el que lanzaría en 1880 Walter Flemming: "Ommnis nucleus ex nucleo».

Entre los comienzos de la teoría celular y la obra de Virchow transcurrirían dos decenios. En ese lapso las mejoras introducidas en el microscopio, los procedimientos más eficaces en la observación de los tejidos, los nuevos métodos de coloración y otros progresos técnicos, permitieron acumular una gran cantidad de hechos y de conjeturas sobre el papel de la célula y de sus componentes. Teoría celular que, en su versión neuronal, incide, de pleno, en la figura de Ramón y Cajal.

De acuerdo con los razonamientos de Louis Pasteur no cabía duda de que los microorganismos eran seres vivos acarreados por el aire at mosférico y depositados, constantemente, sobre todos los objetos como ya lo habían entrevisto Cagniard de la Tour y Theodor Schwan. Sin embargo, la tesis opuesta, es decir la tesis espontaneísta según la cual los microorganismos se originan por la descomposición de los líquidos fermentables, efecto y no causa del proceso, se vio nuevamente apoyada en la época de las investigaciones ya bosquejadas de Pasteur por el naturalista francés Felix Archimede Pouchet, cuyo grueso libro: «Heterogénie ou Traité de la Generation Spontanéor de 1859, reunía el conjunto de los argumentos a favor de la antigua teoría. A ese respecto y ese mismo año, 1859, la Academie des Sciences de París organizó un concurso en torno del problema; hecho que dio pie a una célebre controversia entre Pasteur 


\section{La época de Santiago Ramón y Cajal}

y sus adversarios acerca del origen de los microorganismos. En el año 1888 se fundó el Instituto Pasteur, año que Cajal, quién reconoció haber sido partidario, en principio, de la generación espontánea, califica como «i año cumbre mi año de fortunoo. Cajal, instalado en Barcelona, de cuya Universidad había ganado la Cátedra de Histología Normal y Patológica el año anterior, declara que «la nueva verdad, laboriosamente buscada y tan esquiva durante años de varios tanteos, surgió de repente en mi espíritu como una revelación. Las leyes que rigen la morfología y las conexiones de las células nerviosas en la sustancia gris, patentes primeramente en mis estudios del cerebelo, confirmáronse en todos los órganos sucesivamente explorados. ... Excluida la continuidad substancial entre célula y célula, se impone la opinión de que el impulso nervioso se transmite por contacto, ....

Con todo, el origen microbiano de las infecciones sería zanjado por el alemán Robert Koch quién, en 1876 publicó la demostración definitiva, por primera vez, de la etiología de una enfermedad infecciosa: el carbunco. Luego, en 1878 - Cajal, con 26 años, obtiene en Madrid el grado de Doctor-, puso en evidencia que los microorganismos patógenos son específicos, es decir, que cada tipo de microbio propaga una sola y determinada enfermedad, derrumbando la creencia de que los microorganismos podían modificarse pasando de una a otra forma patógena, y en 1882 descubrió el agente propagador de la tuberculosis, el «bacilo de Koch», si bien con ello no concluyeron sus aportaciones.

Los trabajos de Koch dispararon las investigaciones en bacteriología y especialmente en parasitología en la que los trabajos de Ronald Ross sobre la malaria fueron recompensados con el Premio Nobel de Fisiología o Medicina en el año 1902 -año de la muerte de Virchow-, y los de Charles Louis Alphonse Laveran sobre el papel de los protozoos en patología humana en 1907, cuando Cajal colaboraba en la creación de la Junta de ampliación de estudios y cuando fue elegido Académico de la Real Academia Nacional de Medicina.

Por otra parte, sin conocer las publicaciones de Kock, Pasteur obtuvo, en 1881 -ude más enjundia, define Cajal, y de indole más estrictamente objetiva fue mi segundo trabajo "Observaciones microscópicas sobre las terminaciones nerviosas en los músculos voluntarios»-, el espléndido éxito de producir una vacuna contra el carbunco - una enfermedad producida por una bacteria-, y en 1885 -Cajal es reclamado por la Diputación de Zaragoza para estudiar la epidemia de Cólera en la región Levantina y emitir dictamen sobre el valor de la profilaxis, redactando «Estudios sobre el microbio vírgula del cólera y las inoculaciones profilácticass-- con- 
tra la rabia -una enfermedad producida por un virus-. Los trabajos de Pasteur significaron también el punto de partida de la inmunología. Uno de los destacados discípulos de Pasteur, el ruso Ilja Iljitsch Metschnikoff propuso, en 1884, la teoría de que los microbios patógenos al introducirse en el organismo animal son captados y englobados por determinadas células: los fagocitos. El fenómeno señalado por Metschnikoff -la fagocitosis- explica ciertos aspectos restringidos de la inmunidad, pero no aclara sus características generales. Agreguemos de paso que Metschnikoff logró mayor popularidad gracias a sus teorías relativas a la prolongación de la vida humana, que creía conseguir mediante los efectos del bacilo láctico, que neutraliza los "venenos intestinales».

Opuesta al enfoque celular de la inmunidad, una teoría humoral de la misma tuvo su punto de partida en el descubrimiento del químico alemán Hans Büchner, quién puso en evidencia el poder bactericida de la sangre y la presencia en ella de "alexinas", es decir de sustancias bactericidas. Emil Adolf von Behring, Paul Ehrlich y Charles Robert Richet completaron, durante la primera década de nuestro siglo, los conceptos de inmunidad activa y pasiva que sirvieron de base a los desarrollos ulteriores de la inmunología. A Berhing se le otorgó el Premio Nobel de Fisiología o Medicina de 1901, "por su trabajo en la seroterapia, en especial por sus aplicaciones contra la difteria, lo que ha abierto una nueva vía en el dominio de la ciencia médica y con ello ha puesto en las manos del médico un arma victoriosa contra la enfermedad y la muerte», según reza el el preámbulo de la concesión. Cajal. por su parte, ocupa el Laboratorio de Investigaciones Biológicas y publica «Recuerdos de mi vidoo». Paul Ehrlich y Metschnikoff compartieron el Premio Nobel en 1908, en reconocimiento a sus trabajos sobre la inmunidad; mientras, Cajal inicia experiencias sobre trasplante neuronal. Por su parte, Charles Richet se incorporó a la orla de premiados en 1913 en reconocimiento a su trabajo en anafilaxis.

\section{g. El triunfo de la cirugía}

En otro terreno dos innovaciones capitales -la anestesia y la antisepsia- transformaron la cirugía del siglo XIX, ampliando su campo de acción y asegurando progresos mucho más allá de lo soñado por los cirujanos del pasado. Nadie entre éstos pudo prever que la labor de químicos y de microbiólogos prepararía el advenimiento de una nueva era quirúrgica. La anestesia se introdujo al promediar el siglo, siguiéndole tras un in- 


\section{La época de Santiago Ramón y Cajal}

tervalo de casi dos decenios el método antiséptico; de modo que el dolor que sufrían los pacientes bajo el bisturí y la sepsis postoperatoria que provocaba una mortalidad elevada, se mantuvieron durante la primera mitad del siglo XIX como los grandes obstáculos que limitaban los progresos quirúrgicos.

Fue el químico inglés Humphry Davy quién experimentando sobre sí mismo comprobó, en 1799, la notable acción narcótica del óxido nitroso, y al referirse a esa experiencia escribía, en el año 1800, que «probablemente podría utilizarse el gas hilarante ventajosamente durante las operaciones quirúrgicas en las que no se produce considerable pérdida de sangre». A su vez, en 1815, Michael Faraday había señalado el efecto farmacológico del éter; sin embargo, por sorprendente que parezca, ningún cirujano llegó a reconocer los alcances de estas indicaciones; y el joven médico inglés Henry Hill Hickman, que ensayó el efecto del ácido carbónico y del óxido nitroso sobre animales, y que sugirió en 1824 la aplicación de gases narcotizantes a la práctica quirúrgica, no encontró la atención que merecía. La anestesia debía ser un regalo de la odontología americana a la humanidad.

En efecto, fue el dentista Horace Wells, de Conneticut, quién al advertir los servicios que el óxido nitroso podría prestar a la odontología, comenzó a hacer uso del gas hilarante en las extracciones dentarias en 1844. El fracaso de su método en una demostración pública llevó a Wells a retirarse de la práctica profesional. Ni Wells ni su amigo y colaborador el también dentista William Thomas Morton, podían saber que, cuatro años antes, el médico rural Cerwford Wilson Long, de Georgia, había advertido la acción anestésica del éter que había empleado en la extirpación indolora de un pequeño tumor. Pero Long no perece que reconociera los alcances de su experiencia y, durante varios años, se abstuvo de publicarla. Mientras tanto, Morton continuaba buscando un gas con efecto narcotizante seguro y guiado por las informaciones que le suministró el químico Charles Thomas Jackson, eligió el éter sulfúrico, y después de haber efectuado extracciones indoloras en sí mismo y en uno de sus pacientes, propuso al cirujano John Collins Warren realizar una demostración pública utilizando el anestésico en una operación quirúrgica; intervención que se realizó en el Hospital General de Massachussets, extirpando Warren en cinco minutos un tumor de cuello a un paciente anestesiado por Morton. "Caballeros -exclamó el paciente al despertaresto no es charlataneríon. Así, el 16 de octubre de 1846 recibieron una brillante refutación las palabras escritas pocos años antes -en 1839- por el prestigioso cirujano francés Velpeau: «Suprimir el dolor en las operacio- 


\section{Pedro García Barrero y Juan Fernández Santarén}

nes quirúrgicas es una quimeroor. La anestesia abrió las expectativas quirúrgicas a cotas sin límites.

El segundo paso decisivo hacia la nueva cirugía fue dado por el inglés Joseph Lister. En 1865 el cirujano escocés Joseph Lister, guiado por las experiencias de Pasteur, advirtió la relación entre los microorganismos siempre presentes en la atmósfera y las complicaciones purulentas de las heridas quirúrgicas; siendo, por esa época, cuando comenzó a arraigar en el espíritu de Pasteur la idea de la tasmisión de las enfermedades contagiosas por microorganismos. Al introducir la antisepsia, logró un excepcional éxito en la lucha contra la infección postoperatoria de las heridas, terrible amenaza que había acompañado a las intervenciones quirúrgicas desde los tiempos más remotos. La obra reformadora de Lord Joseph Lister partió de la observación de que las fracturas abiertas siempre supuraban, mientras que aquellas en las que la piel estaba intacta se mantenían libres de pus. El problema encontró solución cuando Lister se enteró de las investigaciones de Pasteur y, en especial de los resultados consignados en la publicación Recherches sur la Putréfaction del genial francés, dándose de inmediato cuenta de que la teoría de Pasteur era aplicable a la putrefacción de los tejidos vivos en las heridas. Limpiando las heridas con una sustancia antiséptica -eligió el ácido fénico- logró disminuir la mortalidad, en los casos de amputación, del $45 \%$ al $15 \%$. En 1867 publicó los resultados de sus tratamientos de fracturas abiertas y de abcesos en dos artículos, de los que en particular el segundo de ellos -On the Antiseptic Principles in the Practice of Surgery- señala un jalón en la historia de la cirugía. Pero sus hipótesis y experimentos le aportaron violentos ataques, en especial en la Academia de Medicina por parte de un grupo importante de clínicos.

Junto con la anestesia, la asepsia fue garante de la consolidación de la cirugía como actividad científica. Las figuras del suizo Emil Theodor Kocher, recipiendario del Nobel de Medicina en 1909 -Cajal, fellow de la Royal Society, inicia una vasta investigación sobre histología comparada- por su trabajo sobre la fisiología, patología y cirugía de la glándula tiroides, y del franco-americano Alexis Carrel, recompensado con el preciado galardón en 1912 -Cajal ensaya nuevos métodos de investigación: el del formol-urano y el del sublimado-oro- por su trabajo sobre la sutura vascular y los trasplantes de órganos, son claros ejemplos de la ciencia quirúrgica.

En los últimos años del siglo XIX, los rayos X descubiertos por el físico alemán Wilhem Konrad Röntgen enriquecieron el arte de curar con un nuevo y maravilloso instrumento diagnóstico. «Si se interpone-escribió 


\section{La época de Santiago Ramón y Cajal}

en su primera memoria el descubridor- // si se interpone la mano entre el tubo de descarga y la pantalla fluorescente, la sombra más oscura de los huesos se destaca entre la sombra de la mano levemente menos oscura». Estas líneas constituyeron el punto de arranque de la radioscopia y de la radiografía, permitiendo que los rayos X pudieran ser aplicados a fines diagnósticos casi inmediatamente después de difundirse la noticia del descubrimiento. Röntgen fue el primer científico al que se concedió el Premio Nobel, fue en el año 1901; noticia que fue celebrada unánimemente por el mundo científico a excepción de Philipp Lenard, quién se consideró, siempre, el verdadero descubridor de los rayos X. A Lenard le otrogaron el Premio Nobel de Física en 1905 - Cajal emprende la investigación sobre la regeneración nerviosa; estudia la arquitectura de los ganglios sensitivos y simpáticos, y se consolida la «concepción neuronaly-por su trabajo sobre los rayos catódicos. Röntgen y Lenard, amigos hasta entonces, nunca, a partir de la concesión del Premio Nobel al primero, vọlverían a hablarse.

\section{h. El estudio del alma}

Cambiando de escenario, también durante el siglo XIX las investigaciones psicológicas, tanto en situación normal (psicología médica) como patológicas (psiquiatría), proclamaron su autonomía científica, que luchaba por colocarse bajo los signos de la ciencia de la época: medida, experimentación y objetividad. Las investigaciones anatómicas habían abierto el camino: Franz Joseph Gall, investigando el origen del pensamiento y de las emociones, tras disecar numerosos cerebros, inventó la frenología, y Paul Broca localizó la sede de la facultad del lenguaje articulado al pie de la tercera circunvolución frontal izquierda. Por otro lado, los fisiólogos Ernst Heinrich Weber, quién definió los conceptos de «umbral de excitación» y de "umbral diferencial», que se recogieron en la ley de Weber, y Gustav Theodor Fechner, quién introdujo el término psicofísica. Con tales antecedentes anatómicos y fisiológicos, el fundador de la psicología experimental y precursor de la psicología comparada es Wilhem Wundt, fundador del primer laboratorio sobre el tema y que en 1886 - Cajal publica su primer trabajo en una revista extranjera, Internationale Monatschrift $f$ Anat $u$ Physiol Bd III. Heft 7: "Contribution à l'etude des cellules anastomosées des épithéliums pavimenteux strstifiés-- fue reconocido oficialmente como Instituto de Psicología de la Universidad de Leipzig. Entre los discípulos de Wundt destacó el americano James 
McKeen Cattell, a quién se debe el término universal "test». La psicología entraría en el nuevo siglo de la mano de tres escuelas bien asentadas: el conductismo o behaviorismo del americano John Broadus Watson -estudio de las respuestas que el organismo considerado como un todo realiza en respuesta a un estímulo-; la psicología de la Gelstat del austriaco Christian von Ehrenfels -en toda percepción el todo es algo más que la suma de las partes-, y la teoría de los reflejos condicionados del ruso Ivan Petrovich Pavlov; teoría expuesta en Madrid, en el Congreso Internacional de Medicina del año 1903 -Cajal logra una nueva fórmula de impregnación argéntica- y que le valdría el Premio Nobel en el año 1904 -Cajal concluye la Textura del sistema nervioso del hombre y de los vertebrados, la "obra de su vida, y la Academia de Ciencias de Berlín concede a Cajal la medalla Helmholtz-. En relación con el trabajo de Pavlov, sirvan de referencia los importantes estudios llevados a cabo en el salto al siglo XX sobre fisiología sensorial, en especial de la visión de la mano del sueco Allvar Gullstrand y del aparato vestibular de la del vienés Robert Bárány.

En el campo de la patología, la revolución psiquiátrica que se produjo a fines del siglo, aunque parezca paradójico, tuvo su origen en aquel movimiento de escaso valor científico que fue el mesmerismo o «doctrina del magnetismo animal» fundada por Franz Joseph Mesmer sobre la base de una mezcolanza de concepciones metafísicas, de teorías físicas de la época como la gravitación universal y de antiguas doctrinas médicas -el organismo está impregnado de un fluido magnético universal- en 1843 derivó hacia el hipnotismo - a cuya actividad dedicó Cajal algún tiempo, incluida la organización de un Comité de Investigaciones Psicológicas, durante su estancia en Valencia-. El hecho es que, a finales del siglo, el hipnotismo estaba establecido como método de tratamiento y como tema de investigación en dos escuelas francesas: la de La Salpê trière de París dirigida por Jean-Martin Charcot, escuela más investigadora y sistematizadora; y la de Nacy dirigida por Hippolyte Bernheim, más empírica, humanitaria y con preocupaciones sociales. Sin embargo, a fines de siglo el auge del hipnotismo tiene fin ante la aparición de un nuevo astro de la ciencia médica: Sigmund Freud.

Cuando Cajal termina su compromiso con la Diputación de Zaragoza y regresa a Valencia y, definitivamente, a la Histología, en 1885, Freud inicia su carrera docente en la cátedra de neuropatología de la Universidad de Viena. Ese mismo año obtiene una beca y se pone en contacto con la clínica de Charcot y con el estudio de la histeria y la aplicación del hipnotismo. Regresa a Viena pero cuando oye hablar de la clínica de Nancy, 


\section{La época de Santiago Ramón y Cajal}

realiza un segundo viaje a Francia, en 1889 -Cajal asiste al Congreso de la Sociedad Anatómica para presentar su trabajo0; "en Nacy -relata Freud-recibí las impresiones más profundas ante la posibilidad de que existieran procesos mentales que, sin embargo, permanecían ocultos a la conciencia de los hombres». Con esta nueva concepción de la enfermedad psiquiátrica se asocia con un médico vienés: Josef Breuer, quién usaba la hipnosis con sus pacientes neuróticos, y de la labor común aparece un primer ensayo, en 1893 - Cajal publica un trabajo sobre tumores hepáticos-, y dos años más tarde un libro: Studien über Hysterie, que marca un jalón en la historia de la psicología médica, y en el que hacen su aparición dos nuevos conceptos fundamentales de la psicoterapia del siglo XX: la represión y el inconsciente.

Más tarde Freud descubre que puede prescindir del hipnotismo utilizando un nuevo método terapéutico llamado de las asociaciones libres, en el que el paciente, hablando al azar, vencía los obstáculos reprimidos. El análisis e interpretación de lo que el paciente dice se denominó psicoanálisis. En ese análisis desempeña un papel importante el material de los sueños, cuya interpretación motivó uno de los magistrales libros de Freud: Die Traumdeutung, en 1900; y cuando publica otra de sus obras fundamentales: Zur Psychopathologie des Alltagsteben (La Psicopatología de la Vida Cotidiana), el psicoanálisis muestra una de sus carácterísticas esenciales: su extensión a la vida normal y la supresión de todo límite neto entre psicología normal y patológica, mostrando también en el campo de la psicología la validez del principio biológico, que ya había sostenido Claude Bernard, de que no existe una clara línea divisoria entre la salud y la enfermedad. Pronto aparecerían las primeras divergencias de la mano de dos de sus discípulos iniciales: el suizo Carl Gustav Jung y el austriaco Alfred Adler.

\section{i. La Fisiología: protagonista del s XIX}

Aprovechemos la figura de Claude Bernard para cambiar de tercio. La Fisiología del siglo XIX se distingue por la construcción de instrumentos y el uso sistemático de técnicas de detección y de medición. El reconocimiento sin reservas de la Física y de la Química como ciencias piloto permite a los fisiólogos adaptar al estudio de las cuestiones biológicas las técnicas de análisis y de medición que suministraban la prueba de su validez en el dominio de los fenómenos inorgánicos. Desde el punto de vista de la instrumentación física, el impulso en cuestión se 


\section{Pedro García Barrero y Juan Fernández Santarén}

remonta a Poiseuille, y desde el punto de vista de las técnicas químicas, a von Liebig. Pero el hecho de que la Fisiología se constituya como ciencia en el siglo XIX por la sólida unión de esos dos estilos de investigación se debe a que desde los trabajos de Lavoisier y Laplace, el problema fundamental de la vida de los organismos es el problema de las fuentes y las leyes de utilización de la energía, y del metabolismo. Metabolismo que fue de la mano de importantes avances en nutrición; Frederick Gowland Hopkins señaló en 1906 - Cajal, en la cúspide, recibiría ese año el Premio Nobel en Fisiología o Medicina- que un régimen constituido por proteínas purificadas, grasas, hidratos de carbono y minerales era evidentemente insuficiente, y que otras varias sustancias presentes en los alimentos naturales eran esenciales para una buena nutrición. Hopkins sería galardonado en el año 1929 por su descubrimiento de las vitaminas estimulantes del crecimiento. Por su parte, Albrecht Kossel, que había colaborado en el descubrimiento del ciclo de la urea, inició el estudio de las nucleoproteínas, descubriendo que las piezas elementales de los ácidos nucleicos son el ácido fosfórico, una base nitrogenada y un azúcar. Por su trabajo sobre el metabolismo de las proteínas y de las sustancias nucleicas recibió el Premio Nobel de Fisiología en el año 1910 -Cajal afianza la teoría neurotrópica: "sustancias neurotrópicas fabricadas por el tejido conectivo embrionario»-.

Unas veces más respetuosa de la especificidad de los procedimientos, ya que no de leyes, de la vida como en el caso de Claude Bernard; otras más sometida a la legislación de la Física y de la Química, como en el caso de Ludwig, y otras más aplicada a la imitación del modelo matemático, como en el caso de Hermann Helmmholtz -para quién se creó la primera Cátedra de Fisiología en Heidelberg, en 1858- la Fisiología del siglo XIX manifestó, a pesar de todo, cierta unidad de inspiración y de proyecto. Es la ciencia de las constantes de funcionamiento de los organismos. Uno de los indicios de que, entre Magendie y Sherrington y Pavlov, la Fisiología se constituyó como ciencia auténtica, es el gran número de casos en que se sumaron las investigaciones, y hasta se consiguieron simultánea e independientemente los mismos descubrimientos, con discusión de prioridad o sin ella. La historia de la Fisiología se hizo relativamente independiente de la historia de los fisiólogos. Desde el momento en que técnicas y problemas se concilian y suscitan recíprocamente, y en que los instrumentos son lo bastante especializados y complicados como para que su uso implique la adhesión a hipótesis de trabajo, hay que decir que la ciencia hace a los científicos tanto como estos a aquélla. Cuando la investigación tiene ya rasgos de oficio y puede en rigor pres- 


\section{La época de Santiago Ramón y Cajal}

cindir por algún tiempo de apasionamientos, entonces merece el nombre de ciencia experimental.

\section{j. Europa, 1914}

Mas, que sólo tenga derecho a existir una interpretación del mundo es, al menos, ingenuidad» escribió Federico Nietzsche en su Gaya Ciencia. Esas palabras son algo más que una diatriba contra la positivación de la vida; son la repulsa del positivismo y la afirmación de un nuevo modo de intuir y concebir la realidad. En las postrimerías del siglo XIX empezó a cobrar cuerpo una actitud frente a la naturaleza fundamentalmente dis tinta de la que Comte y los positivistas ulteriores habían sostenido. De esa nueva actitud fueron expresión el resuelto anti-intelectualismo de Nietzsche y de Bergson, el pragmatismo de William James, el neovitalismo de Driesch, la filosofía de Dilthey o la crítica del conocimiento científico; actitud esta última en la que se distinguieron el francés Pierre Duhem y el austriaco Ernst Mach. Duhem demostró que el acuerdo con la experiencia no garantiza por completo la verdad de una teoría, y Mach, extremando su fidelidad metódica a los principios del positivismo, según los cuales el hombre de ciencia no debe atenerse sino a lo que por su experiencia le consta, redujo los hechos, las leyes y la causalidad mecánica a una composición de sensaciones adaptada a las necesidades de la vida.

Todos estos sucesos, unidos ya a la incipiente crisis de la física clásica, determinaron la publicación de un resonante artículo de Brunetière sobre «la bancarrota de la ciencia». Bancarrota que es expresión a todas luces desmesurada, pero muy significativa de la vicisitud que entonces se iniciaba en la historia del espíritu humano y que concluyeron en nuestro entorno con la crisis de 1898, y en Europa con la eclosión de la Gran Guerra, que tuvo efectos devastadores en la comunidad científica -un golpe rudísimo", en palabras de Cajal; quién continúa: "durante seis años quedé incomunicado con los laboratorios extranjeros y reducido a un monólogo ....t-. Al terminar la contienda, don Santiago recibió la noticia dela muerte de los que, en el extranjero, se consideraban amigos: van Gehuchten, Waldeyer, Ehrlich, Retzius, Edinger, Krause, ... Algunos de ellos fueron firmantes del «Manifiesto de los 93». A los pocos días de su publicación se hizo circular un «contradocumento, el «Manifiesto a los europeos» que sólo firmaron cuatro personalidades. «Nunca jamás una guerra ha interrumpido tan intensamente la cooperación culturab comenzaba el documento que concluía: «... a todos aquellos a los que Goethe 
proféticamente llamó buenos europeos. Si piensa como nosotros, si también está decidido a crear un amplio movimiento a favor de la unidad europea, entonces le rogamos que contribuya con su firmos. El manifiesto no encontró apenas apoyo; únicamente consiguió aquellas cuatro firmas. Seguro que Cajal, de haber tenido a él acceso, lo hubiera endorsado.

\section{Panorama de las Ciencias de la Vida en España}

\section{A. Introducción}

Entre el fracaso de la Revolución liberal de 1848 y el comienzo de 1 Guerra Europea en 1914, fechas que enmarcan el Positivismo, discurrirá el grueso de nuestra historia; sin embargo, los bordes serán flexibles. Por su parte, el texto mostrará dos partes claramente diferenciadas: las ciencias naturales -en nuestro caso, las ciencias de la vida o biología- y la medicina; aunque indudablemente existen solapamientos. En un sentido muy amplio puede llamarse "positivismo» a toda doctrina que se atiene a, o destaca la, importancia de los positivo, esto es, de los que es cierto, efectivo o verdadero. En su sentido más estricto -comenta Ferrater Mora- y de acuerdo con su significado histórico "positivismo» designa la doctrina y la escuela fundadas por Augusto Comte (Montpellier, 17981857), quién desarrolló y propuso una «filosofía positiva» que comprendía no sólo una doctrina acerca de la ciencia, sino también y sobre todo, una doctrina sobre la sociedad y sobre las normas necesarias para reformar la sociedad, conduciéndola a su «etapa positiva». Como teoría del saber el positivismo no admite otra realidad que no sean los hechos y sus relaciones. El positivismo rechaza el conocimiento metafísico y se atiene a lo dado. De todo ello derivan varias características: hostilidad a toda construcción y deducción, a la sistematización y reducción de la filosofía a los resultados de la ciencia y, finalmente, naturalismo. Casi coetáneo de Comte es Karl Christian Friedrich Krause (Sajonia, 1781-1832) y, al igual que el primero, no logró obtener nombramiento universitario alguno; ambos padecieron penurias económicas importantes y, ambos, lograron formar grupos de discípulos muy fieles. Krause aspiraba a ser la auténtica continuación de Kant contra lo que el autor consideraba las falsas interpretaciones de Fichte, Schelling o de Hegel. Como en el caso del positivismo, el krausismo es una doctrina sobre la sociedad; rechaza la teoría absolutista del estado y acentúa la importancia de las asociaciones llamadas de finalidad universal sin sacrifico de su peculiaridad-familia 


\section{La época de Santiago Ramón y Cajal}

o nación-frente a las asociaciones limitadas -Iglesia o Estado-. Con ello se llega a una federación mundial, al ideal de una Humanidad unida que proporcione a cada uno de sus miembros la participación en la razón suprema y en el Bien. Aunque el krausismo ejerció menos influencias que la de cualquier otro de los grandes pensadores idealistas alemanes de la época no careció, sin embargo, de partidarios que propagaron con ardor sus doctrinas. El krausismo -señala Ferrater- obtuvo su máxima difusión en España con Julián Sanz del Río (1814-1869) y su discípulo Francisco Giner de los Ríos (1839-1915); también, Federico de Castro y Fernández (1834-1902), Gumersindo de Azcárate (1840-1917) y otros. El krausismo dejó pronto de ser un movimiento filosófico para convertirse en otro de renovación espiritual y, en particular, educativo; a este respecto fue significativo su influencia en la fundación de la Institución Libre de Enseñanza. Positivismo y krausismo impregnaron, en una particular combinación, la «renovación» del pensamiento español del periodo señalado.

En la segunda mitad del siglo XIX, anulados los efectos del reinado fernandino que liquidó el esfuerzo científico de la Ilustración, se produjo una modesta recuperación de la ciencia española. El proceso fue desencadenado por la constitución de una nueva estructura universitaria en España. La legislación, durante el reinado isabelino, configuró un sistema universitario basado en el modelo francés, centralizado y burocrático, que ponía más énfasis en la formación de profesionales que en la investigación científica. Paradójicamente, aquel modelo universitario que relegaba la investigación permitió la formación de un cuerpo profesoral que contribuyó a difundir la ciencia en nuestro país.

El proceso de incorporación de la actividad científica al quehacer universitario no era una política consciente y asumida por las autoridades educativas. Ello determinó un desequilibrio temático en el desarrollo de las diversas disciplinas científicas: la morfología, geología, mineralogía, botánica y zoología así como las especialidades médicas, alcanzaron en las últimas décadas del siglo XIX un cierto desarrollo. Diversas explicaciones caben ante este fenómeno. De un lado, la existencia de instituciones de sólida raigambre en la estructura administrativa del Estado y con edificios en aceptable estado de uso y conservación: el Real Museo de Ciencias Naturales -continuación del Real Gabinete de Historia Natural proyectado por Antonio de Ulloa, iniciado con la compra de una colección particular en 1772 e instalado en 1775 compartiendo techo con la Real Academia de Bellas Artes de San Fernando, y que, en 1815, tomó su nueva denominación-o el Real Jardín Botánico -ubicado, en 1755, en el Soto 
de Migas Calientes, cerca del actual Palacio de la Moncloa en Madrid y consolidado como Real Jardín del Prado en 1781- eran centros cuya actividad se remontaba al siglo XVIII, contaban con importantes coleccio nes y disfrutaban de una dotación de material y de personal modesta pero no mísera. Por su parte, la existencia de Facultades de Medicina en la práctica totalidad de las universidades españolas y la existencia de hospitales vinculados a ellas proporcionó un sustrato institucional suficiente para el desarrollo de las diversas disciplinas clínicas.

Por otra parte, médicos, farmacéuticos, ingenieros forestales, agrónomos o de minas, eran colectivos de considerable prestigio social, con fuerte conciencia asociativa y, en algunos casos, sólidamente instalados en el escalafón administrativo. En el desarrollo de su actividad profesional y técnica los integrantes de estos colectivos trataban cuestiones de interés científico básico. En cambio, las disciplinas fisicomatemáticas carecieron de colectivos profesionales equiparables; excepción hecha de los ingenieros de caminos, la inexistencia o endeblez de los cuerpos de ingenieros químicos o industriales acentuó el desequilibrio disciplinar de la ciencia española de la Restauración. Con todo, las principales instituciones naturalistas de la época tratada fueron la Real Academia de Ciencias Exactas, Físicas y Naturales (1847); la Real Academia de Medicina (1861); las Escuelas Libres de Medicina y Cirugía (1968); la Sociedad Española de Historia Natural (1871); la Estación Biológica Marítima de Santander (1887); la Junta para Ampliación de Estudios (1907), y la Asociación para el Progreso de las Ciencias (1908).

\section{B. El Contexto Naturalista}

a. Real Academia de Ciencias Exactas, Físicas y Naturales

Hubo que esperar al 7 de febrero de 1834 (un mes después del R.D. de 4 de enero, que recuperaba la libertad de imprenta ya estipulada por los Reyes Católicos; una semana antes del R.D. organizando la Milicia Nacional -16 de febrero-, y un mes antes del Estatuto Real -10 de abril-) bajo la regencia de M. Cristina de Borbón (1833-1841) y estando Martínez de la Rosa al frente del gobierno, en que se produjo un nuevo intento de relanzar el pensamiento científico: el Real Decreto de creación de la Real Academia de Ciencias Naturales de Madrid, constituida en parte por los miembros naturalistas de la Real Academia de Medicina y Ciencias Naturales que poco antes se había extinguido. Sus Estatutos fueron 


\section{La época de Santiago Ramón y Cajal}

aprobados el 16 de septiembre de 1834. Presidida por el Duque de Veragua, la corporación constaba de cuatro secciones: Ciencias Naturales descriptivas, Ciencias Físico-Matemáticas, Ciencias Físico-Químicas y Antropología. Respecto a su corta vida -no hay noticias de que se volviera a reunir después del 28 de febrero de 1843- D. Mariano Roca de Togores en el Documento de justificación para la creación de una Academia de Ciencias exponía a la reina Isabel:

"SEÑORA: Uno de los ramos del saber humano que el Ministerio de mi cargo, creado por V.M. para atender especialmente a la cultura y bienestar de los pueblos que rige, debe promover con preferencia, es el de las Ciencias, Fisicas y Naturales, que tan poderosamente influyen en la Industria y prosperidad de las Naciones, pero que, desgraciadamente, no ocupaban en nuestro antiguo sistema de enseñanza el lugar preeminente que de derecho les corresponde.

En breve, Señora, estarán las Universidades dotadas de los medios necesarios para cultivarlas, y de esperar es que entonces sea su desarrollo tan rápido como provechoso; pero, aun asi, cree el Ministro que suscribe que es indispensable acudir a otros medios no menos eficaces, que en paises extranjeros han contribuido poderosamente al engrandecimiento de aquellas ciencias y a la importancia de sus aplicaciones de todas especies.

Porque no bastan los esfuerzos aislados de los sabios que a tales estudios se dedican para recoger todos los óptimos frutos de un campo tan vasto, que en él se pierde la inteligencia humana, sino que es necesario que aquellos se reunan para conferenciar entre sí, comunicarse sus observaciones, auxiliarse mutuamente $y$, por último, establecer extensas correspondencias con los sabios y las Corporaciones más eminentes del orbe, a fin de que este inmenso comercio de ideas y descubrimientos difunda el saber por todas partes y aparezca el tesoro de la ciencia con los tributos que todos le lleven a porfía. Si las Sociedades puramente literarias han hecho grandes servicios, no les ceden las ciencias en utilidad e importancia, y aun pueden aventajarlas, porque el estudio de la Naturaleza requiere, más todavía que el de las lenguas $y$ otras ciencias, los esfuerzos reunidos de muchos hombres que se dediquen de consuno a arrancarle sus secretos.

Por tanto, se han creado y multiplicado en todos los países cultos las So ciedades consagradas al cultivo de las Ciencia Naturales, y las primeras capitales de Europa se envanecen de que, a la sombra protectora de sus Gobiernos, hayan hecho inmensos trabajos y adquirido justo renombre. 
Varias veces se ha intentado en España seguir tan laudable ejemplo y aun se adelantó en este punto nuestra Nación a todas las restantes, puesto que, desde los años 1580, es decir, mucho antes de que se funden las famosas Sociedades de París y Londres, ya en Madrid existía una Academia Real de Ciencias, de la cual fueron individuos algunos Grandes y Titulos de Castilla. Fue, sin embargo, su existencia harto efimera, tanto que al extinguirse la dinastía austriaca ya no quedaba ni la memoria de ella.

El Marqués de Villena, que en el reinado del Sr. Rey D. Felipe V contribuyó tanto a la creación de la Academia Española, había concebido su primer proyecto bajo un plan más vasto, queriendo que abrazase también todas las ciencias. Posteriormente, al ver los felices resultados que habian producido las de la Lengua y de la Historia, se renovó aquel primer pensamiento, y D. Ignacio de Luzán redactó un proyecto, a consecuencia del cual se mandaron comisionados a varias Academias extranjeras, y aún se compraron máquinas para el uso de la nueva Corporación.

Por desgracia, tampoco produjeron aquellos esfuerzos el resultado apetecido, y la misma suerte cupo a los que en varias ocasiones se intentaron después, particularmente por los ilustres D. Jorge Juan y Don Antonio de Ulloa. Por fin, en el año 1834, la Augusta Madre de V.M., siendo Gobernadora del Reino, aspiró a la gloria de fundar en España una institución tan necesaria, creando por Decreto de 7 de febrero, la Academia Matritense de Ciencias Naturales, que todavía existe; mas ni la época era a propósito para que tal Corporación produjese los frutos que de ella se esperaban, ni se le dieron el carácter $e$ importancia que requería la utilidad de su objeto. Desatendida forzosamente por el Gobierno en virtud de las circunstancias, y sin medios para cumplir debidamente con los fines de su instituto, y aunque más de una vez ha elevado a la Superioridad sabias consultas, yace todavía en un estado de lastimosa postración, pidiendo auxilios y recursos que le den nueva vida y le permitan ser lo que es dado esperar de la ilustración de sus individuos. A V.M. corresponde, Señora, acabar la obra empezada por su Augusta Madre.

En el adjunto proyecto propongo establecer una Academia de Ciencias con igual consideración y con las mismas prerrogativas que tienen las demás Academias Reales. De esta suerte dará V.M. una nueva prueba de la especial protección que le merece cuanto conspira a difundir la ilustración entre sus pueblos, procurando a éstos sus inapreciables beneficios y a V.M. una de las más bellas glorias que ilustrarán su rei- 


\section{La época de Santiago Ramón y Cajal}

nado. Madrid, 25 de febrero de 1847.- Señora: A.L.R.P. de V.M., Mariano Roca de Togores."

Al fin, el Real Decreto de creación de la Real Academia de Ciencias Exactas, Físicas y Naturales:

Ministerio de Comercio, Instrucción y Obras Públicas. Instrucción Pública. $=$ Excmo. Sr. $=$ S.M. se ha dignado espedir con fecha 25 de febrero último el Real decreto que sigue:

"En atención á las razones que me ha espuesto el Ministro de Comercio, Instrucción y Obras Públicas, he venido en decretar lo siguiente:= Artículo primero. Se crea en Madrid una Academia Real de Ciencias exactas, físicas y naturales, que declaro igual en categoria y prerrogativas á las Academias Española, de la Historia y de San Fernando.= Artículo segundo. Declaro suprimida la actual Academia de Ciencias naturales de Madrid = Artículo tercero. La Real Academia de Ciencias Exactas, Físicas y Naturales se compondrá de treinta y seis Académicos. .Artículo sexto. La Academia Real se ocupará inmediatamente de su institución, en formar sus Estatutos, que someterá a mi Real aprobación. ... Dado en Palacio á 25 de febrero de 1847.= Está rubricado de la Real mano.= El Ministro de Comercio, Instrucción y Obras Públicas, Mariano Roca de Togores. - Lo que traslado á V.E., de orden de S.M. para los efectos convenientes. = Dios guarde á V.E. muchos años. Madrid 5 de marzo de 1847.= Roca.= Señor Marqués del Socorro, Presidente interino de la Real Academia de Ciencias exactas, físicas y naturales.

En virtud del Real Decreto fundacional de la Academia, se reunieron en la Biblioteca del Gabinete de Historia Natural, el día 12 de marzo, catorce de los 18 académicos que la Reina, por una sola vez y de un total de 36 medallas, había designado: Marqués del Socorro, Presidente; Joaquín Alfonso, Director del Conservatorio de Artes; Joaquín Ezquerra, Ingeniero de Minas; Donato García, Profesor de Mineralogía de la Universidad Central; Fernando García Sanpedro, Oficial del Real Cuerpo de Ingenieros y matemático; Mariano de la Paz Graells, Profesor de Zoología de la Universidad Central; Francisco de Luján, Oficial del real Cuerpo de Artillería; Mariano Lorente, Secretario; Vicente Santiago Masarnau, Profesor de Química; José Odriozola, del Real Cuerpo de Artillería y matemático; Pedro María Rubio, Médico de Cámara; José Sánchez Cerquero, Director del Observatorio Astronómico de San Fernando; Mateo Seoane, Vocal del Consejo de Instrucción Pública; Juan Subercase, Inspector del 


\section{Pedro García Barrero y Juan Fernández Santarén}

real Cuerpo de Ingenieros de Caminos, Canales y Puertos; Francisco Travesedo, Profesor de Cálculos sublimes de la Universidad Central; Vicente Vázquez Queipo, Diputado a Cortes, y Antonio Moreno, del Consejo de Instrucción Pública.

El día tres de abril de 1847 se proveyeron, por votación, las 18 plazas de académicos de número que se hallaban vacantes. Los Estatutos se aprobaron con fecha 23 de diciembre de 1847, siendo Bravo Murillo el Ministro de Comercio, Instrucción y Obras Públicas. En el mismo año se creó la Velada de Artistas; el nuevo Banco Español de San Fernando, así como se dispuso la Ley de Propiedad Intelectual. Dos iniciativas tuvo la recién estrenada Real Academia: dedicar buena parte de sus menguados ingresos a la suscripción de "periódicos extranjeros referentes a las Ciencias, en los países más adelantados», y la formación de un «Diccionario de los términos técnicos usados en todos los ramos de las Ciencias que forman el objeto de las tareas de la Corporación" (ambas tomadas en sesiones correspondientes al año 1848). La Revista de los Progresos de las Ciencias Exactas, Físicas y Naturales inició su andadura en 1850; en la "Advertencia Preliminar», que abre el Tomo I, puede leerse:

"La Academia Real de Ciencias, ocupada desde su creación en las tareas propias de su instituto, ha mirado siempre como una de las principales entre cuantas reclama el estado de instrucción en España, la de formación de un resumen o análisis de lo mas notable que contengan las actas y periódicos nacionales y extranjeros. Los estatutos de la Academia, prescindiendo de su opinión en este punto, establecen y encomiendan á su cuidado terminantemente en el artículo 28 y siguientes, el trabajo de formar este resumen con el título de Revista de los progresos de las ciencias exactas, físicas y naturales, que para uso exclusivo de los académicos viene formando desde el principio del actual curso académico; es decir, desde que la corporación se vió organizada de modo que pudiera comenzar á llenar los fines de su establecimiento; pero no satisfecho el celo de sus individuos, por una parte, con dejar á ellos circunscrita la utilidad, prácticamente reconocida entre to dos, de tener á la vista un estracto de los descubrimientos, investigaciones y estudios mas notables con que incesantemente es está dando impulso á las ciencias dentro y fuera de nuestro pais, y juzgando sin aventurarse, por otra, que en España no debe ser muy grande el número de personas que pueda reunir una colección de periódicos científicos tan estensa y escogida como la que posee la Academia, ha 
creido esta que podria redundar en beneficio general la publicación de una tarea, por cuyo medio lograrian fácilmente y sin dispendios tener noticia las personas estudiosas de los trabajos actuales, y seguir con fruto utilizando los numerosos adelantamientos que de dia en dia imprimen una marcha rápida á todas las ciencias, y en especial á las físico-matemáticas y naturales. Este trabajo que no se desdeñan de dar á luz otras corporaciones, aun en los paises donde mas adelantada se halla la ilustración y mas abundantes son las producciones originales, se ha hecho ya una necesidad de los hombres estudiosos, porque su auxilio ven reducido á compendio todo lo relativo á descubrimientos nuevos, á observaciones modernas, y á esclarecimiento de puntos, si no ignorados, en alguna manera oscuros ó incompletos; $y$ como en la rapidez del vuelo que han tomado las ciencias, y con la asombrosa facilidad de propagar á millares de impresos, se ha hecho casi imposible á la mayor parte de personas la adquisición de todo lo que ve la luz pública, se ha pensado en todas partes en presentar reducido á estracto cuanto digno de notarse aparece en los demas paises, adoptando este camino para difundir los conocimientos entre todos, y poner al corriente de los del dia á los que de otra manera no podrían adquirirlos. Al presentar la Academia estas razones de conveniencia está muy distante de ofrecer esta tarea como un verdadero trabajo académico, cuando por el contrario conoce que su mérito quedará reducido al de una sucinta compilación de estudios, experimentos y observaciones agenas; $y$ si bien esta consideración hubiera bastado por si sola para hacerla titubear en el pensamiento de la publicación, temiendo que desdijese de la severa dignidad que caracteriza á las corporaciones científicas, todavía juzga con algun fundamento que, aparte de sus memorias ó trabajos originales, podia prestar con este ensayo un especial servicio á los amantes de las ciencias, colocándose entre los hombres ilustres que en otros paises las cultivan y los que en el nuestro no tienen posibilidad de adquirir sus producciones. Con solo lograr este objeto, la Academia habrá cumplido uno de los fines de su instituto, que es difundir entre nosotros los conocimientos científicos, siquiera no alcance por el medio escogido ni la honrosa distinción, ni el mérito que acompaña á publicaciones de otra especie. Y con tanta mas libertad se decide la Academia á poner en práctica este medio sencillo de generalizar aquellos conocimientos, cuanto que ocupada sin levantar mano en la formación de un diccionario técnico de ciencias y en la reunion de memorias originales de sus miembros, no teme que pueda abrigarse la sospecha de que abandone sus verdaderas obligaciones 
por atender á objetos que, aunque muy laudables, son sin embargo de indole muy diferenter.

Se editaron, muy irregularmente, 22 tomos de la Revista entre 1848 y 1905. Un año antes, en 1904, la Real Academia comenzó la edición de la Revista de la Real Academia de Ciencias Exactas, Físicas y Naturales, sin que apareciera nota alguna al respecto en su Tomo I; Revista que perdura en la actualidad. El Tomo I de la "nueva» Revista incluye dos trabajos de Ramón y Cajal: «Un método de coloración de los cilindro-ejes de las células nerviosas» (pgs 7-16), y «El aparato tubuliforme del epitelio intestinal de los mamíferos» (pgs 17-21). Además, la Real Academia editó unas Memorias de las que una $1^{a}$ serie -incluía trabajos de las tres Secciones Académicas- se extendió desde 1850 hasta 1929, y una $2^{\text {a }}$ serie que distingue las diferentes Secciones: Exactas a partir de 1930, Naturales a partir de 1931 y Físico-Química desde 1935.

\section{b. Sociedad Española de Historia Natural}

A la existencia de un marco institucional mínimo y de colectivos profesionales se sumó la libertad de asociación fomentada durante el Sexenio Revolucionario; ello determinó un espectacular aumento de las sociedades científicas. La Sociedad Española de Historia Natural, la más duradera de las sociedades científicas nacidas al amparo del Sexenio, se creó en Madrid en 1871 -año en que Ramón y Cajal encauzaba la terminación de los estudios de la Licenciatura en Medicina en la Universidad de Zaragoza- gracias a la iniciativa de un grupo de naturalistas con el objetivo principal del cultivo de la Historia Natural. Sociedad creada con el aliento de Laureano Pérez Arcas (1824-1894), como corporación científica con la pretensión última de publicar una revista que tenía como antecedentes los Anales de Historia Natural en los que el Prólogo del Num $\mathrm{I}^{\circ}$, correspondiente al mes de octubre de 1799, recoge:

"La Historia Natural ha llamado en todos los tiempos la atención de los hombres ... Deseando el Rey, á exemplo de otras naciones cultas, se publique en sus estados un Periódico, que no solo presente á los nacionales los descubrimientos hechos y que vayan haciendo los extranjeros, sino tambien los que sucesivamente se hacen en España en la Mineralogía, Química, Botánica y otros ramos de la Historia Natural, ha resuelto $S$. $M$. confiar á D. Christiano Herrgen, D. Luis Proust, D. Do- 


\section{La época de Santiago Ramón y Cajal}

mingo Fernández y D. Antonio Josef Cavanilles la redacción de esta importante obra, que se imprimirá en su Real imprenta baxo el nombre de Anales de Historia Natural. Madrid y 30 de Setiembre de 1799 ».

El $\mathrm{Num}^{\circ} 7^{\circ}$ la Revista modificó su nombre por el de Anales de Ciencias Naturales. La Advertencia que abría el número correspondiente al mes de enero de 1801 manifestaba que:

"El título de Historia Natural que dimos á estos Anales nos pareció el debido para empezar á reunir en un cuerpo los descubrimientos nacionales y extranjeros, hasta que un mayor número de memoerias pidiese ampliar los estrechos límites prefixados al principio. ... Habiéndose realizado estas justas esperanzas, mudamos el antiguo título de esta obra en el de Anales de Ciencias Naturales, para que sin contravenir á él podamos publicar lo perteneciente á la historia natural, y á las ciencias que por qualquier título tratan de la naturaleza ...".

Con este título renovado -Anales de Ciencias Naturales- se publicaron los números 7 al 20 (tomo séptimo, abril 1804). El último número de la Revista, el número 21, tomo séptimo, de mayo de 1804 recuperó la denominación inicial de Anales de Historia Natural.

La nueva Revista, las Memorias de la Real Sociedad Española de Historia Natural, debería incluir:

"... los catálogos totales o parciales de las producciones de una localidad determinada, la descripción de especies nuevas, la crítica de las ya publicadas, e igualmente las monografías de un grupo particular de seres naturales cuando haya suficientes datos para ello, y las noticias parciales acerca de la gea, flora y fauna de la Península y sus provincias ultramarinas".

Quedaban, por tanto, fuera de su objeto principal de estudio -señala Baratas Díaz- cuestiones sobre Fisiología y Morfología microscópica de los seres vivos; disciplinas que carecían de una sólida tradición investigadora en nuestro país. No obstante, tras los primeros años de consolidación, la Sociedad atrajo a su seno no sólo a naturalistas, también a médicos, farmacéuticos, ingenieros de montes, etc. El rango temático de la publicación se amplió considerablemente, y empezaron a ser habituales en sus páginas trabajos sobre morfología microscópica de los seres vivos 
y, en menor medida, estudios sobre fisiología. Durante los últimos años del siglo XIX la Sociedad promovió y amparó diversas iniciativas para favorecer la introducción de dichas disciplinas en los institutos de investigación españoles. Entrado el siglo XX las publicaciones de la Sociedad serían un excelente elemento de difusión de los trabajos experimentales realizados en España. Finalmente, el proceso de incorporación de los estudios biológicos experimentales a la actividad de la Sociedad llegaría a su culminación en los años treinta, con la absorción de la Sociedad Española de Biología y la aparición de la Revista Española de Biología.

La actividad editorial de la Sociedad fue, entre 1871 y 1936 , especialmente notable. La Sociedad publicó, en diversos momentos y en ocasio nes de forma simultánea varias revistas. Los Anales de la Sociedad Española de Historia Natural se mantuvieron entre 1872 y 1901, fecha a partir de la que la Sociedad se comprometió en dos publicaciones regulares: el Boletín (1901-1950) y las Memorias (1903-1935). A partir de 1950, el Boletín continuó como tres series independientes: las Actas, desde 1950; la Sección Biológica, desde 1956, y la Sección Geológica, desde 1961. A partir de 1932, y tras ser absorbida la Sociedad Española la Sociedad Española de Biología por la de Historia Natural, esta se hizo cargo del Boletín de la Sociedad Española de Biología (1911-1928) que pasó a denominarse Revista Española de Biología (1932-1936).

El Tomo primero -1872- de los Anales de la Sociedad Española de Historia Natural inicia sus páginas con una Circular:

"Hace tiempo que entre las personas dedicadas en España al estudio de la naturaleza, se echan de ménos los lazos de mutua union y concierto que en otras naciones facilitan el progreso científico, alentado por la colectiva influencia y sostenido por la oportuna publicidad de todo lo bueno y útil, que sea debido á la actitud individual. Demostrado se halla por larga y triste experiencia, cómo notables trabajos de acreditados naturalistas, cuyos nombres traspasaron los confines de la Península, se hicieron infructuosos, no llegando á terminarse, desvanecida la esperanza de que fuesen conocidos; ó habiéndose terminado, perdieron su novedad é importancia científica por el transcurso de los años. Debe ensayarse por cuantos cultivan actualmente las ciencias naturales en España un comun esfuerzo para evitar en lo sucesivo, dentro de los posibles limites, las dificultades é inconvenientes que se originan del aislamiento, contribuyendo todos á los nobles fines que se propone la Sociedad española de Historia Natural, iniciada en Madrid á impulsos de celo y entusiasmo puramente cientificos. Ninguna 


\section{La época de Santiago Ramón y Cajal}

prueba se exige al que aspire á formar parte de esta Sociedad, ninguna obligación se imponen los socios de presentar en ella sus trabajos científicos, áun cuando se espera confiadamente que comunicarán á sus colegas los descubrimientos que hayan logrado hacer, estando reducidos todos sus compromisos á satisfacer la cuota anual, recibiendo en cambio lo que se publique durante el año. Están llamados, pues, á formar parte de esta Sociedad, no sólo las personas que por aficion ó deber se dedican á las ciencias naturales, sino tambien cuantos crean provechoso y conveniente alentar en España tales estudios, propagar los conocimientos que se refieren á este ramo del saber humano, y dar á conocer las producciones naturales del país. Tan importante objeto tendrán los Anales de la Sociedad española de Historia Natural, y en ellos se insertarán preferentemente los catálogos totales ó parciales de las producciones de una localidad determinada, la descripción de especies nuevas, la crítica de las ya publicadas, é igualmente las monografías de un grupo particular de séres naturales, cuando haya suficientes datos para ello, y las noticias parciales acerca de la gea, flora y fauna de la península y sus provincias ultramarinas, todo acompañado de grabados y láminas necesarias. El adjunto Reglamento manifiesta en sus pormenores cuáles son los intentos de la naciente Sociedad, $y$ es de esperar que suficientemente enterado, tanto del objeto como de la organización acordada por la misma, se servirá $V$. manifestar si gusta inscribirse como socio fundador ú ordinario. Madrid 15 de Marzo de 1871. Ignacio Bolivar, Miguel Colmeiro, Joaquin Gonzalez Hidalgo, Pedro Gonzalez de Velasco, Marcos Jiménez de la Espada, Rafael Martinez Molina, Francisco de Paula Martinez y Saez, Patricio Maria Paz y Membiela, Sandalio de Pereda y Martinez, Laureano Perez Arcas, José Solano y Eulate, Serafin de Uhagon, Juan Vilanova y Piera, Bernardo Zapater.

A continuación, el Reglamento de la Sociedad cuyo Artículo primero establece que:

"Se constituye en Madrid una Sociedad Española de Historia Natural, cuyo objeto es el cultivo y adelantamiento de esa ciencia, principalmente por medio del estudio de las producciones naturales de España y sus provincias ultramarinas, y de la publicación de cuanto á dichas producciones se refiera". El artículo $2^{o}$ : "El número de socios será ilimitado, pudiendo pertenecer á la Sociedad tanto los españoles como los extranjeros". ... Artículo $9^{\circ}$ : "Las publicaciones de la Socie- 
dad llevarán el título de Anales de la Sociedad española de Historia Natural, y aparecerán por cuadernos, formando al fin del año un volumen completon. ....Artículo 19. No será permitida discusión alguna que sea extraña al objeto científico dela Sociedad. ... Madrid 15 de marzo de 1871. El Secretario, Joaquín Gonzalez Hidalgo; el Presidente, Miguel Colmeiro.

En enero de 1901, la Sociedad presentó para su aprobación en el Gobierno Civil unas modificaciones de los Estatutos:

"Art. 23. La SOCIEDAD ESPAÑOLA DE HISTORLA NATURAL hará dos publicaciones regulares, sin prejuicio de las extraordinarias que pudiere convenirle dar á luz por razones especiales: serán aquellas: $1^{\circ}$ El BOLETÍN. $2^{\circ}$ Las MEMORIAS de la Sociedad. El BOLETÍN se publicará por meses, excepto los de vacaciones, y comprenderá el extracto del acta de las sesiones y las comunicaciones que se hagan á la Sociedad ... Las MEMORIAS aparecerán por tomo completos con numeración correlativa, comprendiendo necesariamente estudios sobre los tres grupos de seres naturales, siempre que hubiere materiales para ello; $y$, tendrán cabida en ellas, los estudios generales sobre Biología, los descriptivos y oceanográficos, los trabajos sinópticos y monografías, los necrológicos y bibliográficos y los catálogos de las producciones naturales de la Península Ibérica y Baleares".

La Junta Directiva de la Sociedad Española de Historia Natural para el año 1901 fue: Presidente, Blas Lázaro é Ibiza; Vicepresidente, Federico Oloriz y Aguilera; Tesorero, Ignacio Bolívar y Urrutia; Secretario, Salvador Calderón y Arana; Vicesecretario, José María Dusmet y Alonso; Bibliotecario, Rafael Blanco y Juste; Vicetesorero, Antonio García Varela. Existía una Comisión de publicación y otra de catálogo; así como Secciones en Sevilla y en Zaragoza. Los 337 socios se dividían en protectores (5), correspondientes extranjeros (39), numerarios (274) y agregados (19).

En la Sesión correspondiente al día uno de febrero de 1950, bajo la Presidencia de Ismael del Pan Fernández, la Sociedad Española de Historia Natural abordó la:

"Modificación en la distribución de materias del Boletín de la Real Sociedad Española de Historia Natural. De acuerdo con lo dispuesto en la sesión extraordinaria celebrada el día 7 de diciembre de 1949, la Comisión nombrada para estudiar y presentar un proyecto de modifi- 


\section{La época de Santiago Ramón y Cajal}

cación del boletín, según lo discutido y en principio aprobado por aquella Asamblea. Esta Comisión presenta a la consideración de los señores socios las conclusiones siguientes: $1^{a}$. Se estima la conveniencia de modificar la estructura del boletín a partir del año 1950, en el sentido de clasificar y publicar separadamente los trabajos de Geología y Biología en dos secciones, entendiéndose esta separación de las dos ramas de las Ciencias Naturales en su más amplio sentido. ... $4^{a}$. Los números del Boletín llevarán en caracteres bien visibles de su portada la designación de Sección Biológica, Sección Geológica, con la numeración correspondiente al tomo anual que pertenezcan, más una letra entre paréntesis (B), (A) que simboliza la serie a la que se refiere. ... Madrid, 20 de enero de 1950. Firmado: Salustio Alvarado, Salvador Rivas Goday, Carlos Vidal Box».

Junto con los Anales (1872-1901), el Boletín (1901-1950) y las Memorias (1903-1935), la Revista Española de Biología (1932-1936) completa la capacidad editora de la Sociedad Española de Historia Natural. En el Cuaderno $1^{\circ}$ del Tomo I, del día 1 de junio de 1932, puede leerse: «La Revista Española de Biología es continuación del Boletín de la Sociedad Española de Biología -se publicó durante los años 1911 a 1928, el periodo que duró la Sociedad homóloga- y constituye una publicación de la SOCIEDAD ESPAÑOLA DE HISTORIA NATURAL». Santiago Ramón y Cajal figura como presidente de Honor; Pío del Río-Hortega, redactor jefe, y redactores: C. Bolivar, C. Gallástegui, J.H. Guerra, T. Hernando, G. Marañón, J. Negrín, A. Pi Suñer, G. Pittaluga, E. Rioja, M. Tapia, J.F. Tello y A. de Zulueta. I Costero y J.M. Ortiz Picón eran los Secretarios de Redacción. La Presentación expresa:

"Desde hace tiempo constituye un serio problema para muchos biólogos españoles la publicación de sus trabajos científicos, que, con frecuencia, hubieron de buscar acogida en Revistas generales. A ello se debe que algunas publicaciones de verdadero mérito hayan pasado inadvertidas para los investigadores de otros países, y que no pocos descubrimientos hechos en España sean atribuidos a biólogos extranjeros. Para que el fruto, parvo o copioso, de nuestros trabajos sea asequible a todos cuantos se interesan por los asuntos biológicos, precisa les ofrezcamos una Revista especializada que ponga singular cuidado en la perfección de la parte tipográfica $y$, sobre todo ello, de las ilustraciones, cuya importancia no es preciso señalar. Es lo que pretende esta Revista, fundada por acuerdo de las SOCIEDADES DE HISTO- 
RIA NATURAL y de BIOLOGĹA. La SOCIEDAD ESPAÑOLA DE HISTORIA NATURAL proyectó crear una publicación especializada que reuniese los trabajos de sus miembros, dedicados a temas de Biologia general y especial. Por otra parte, la SOCIEDAD ESPAÑOLA DE BIOLOGÍA - cuya vida era precaria por dificultades de diversa índole -, aspiraba a resurgir, para dar satisfacción a los que, cada día en mayor número, se interesan por las Ciencias biológicas. Tal comunidad de anhelos ha determinado la incorporación de la SOCIEDAD DE BIOLOGÍA a la SOCIEDAD DE HISTORLA NATURAL y que ésta se imponga la costosa tarea de crear y sostener la REVISTA ESPAÑOLA DE BIOLOGÍA, que nace con modestia y ajustándose a las posibilidades del momento; pero aspira a hacerse una publicación de categoría comparable a las mejores Revistas biológicas extranjeras. Comenzará apareciendo bimestralmente, pero con el propósito de ampliar sus páginas y de publicarse más frecuentementer.

El número de trabajos de carácter biológico experimental y de morfología microscópica en las publicaciones iniciales de la Sociedad es relativamente escaso; sin embrago, el número de trabajos de carácter biológico experimental y de morfología microscópica fue ascendiendo de manera paulatina hasta la Guerra Civil; acontecimiento que interrumpió la aparición de trabajos biológicos experimentales en un momento en el que se aproximaba a un salto cuantitativo definitivo, que hubiera logrado asentar definitivamente el desarrollo de la experimentación biológica en nuestro país. El análisis global por disciplinas revela un cambio radical frente a los datos iniciales: un dominio absoluto de los trabajos de histología y morfología microscópica. La morfología microscópica, además, se mantuvo como la disciplina mayoritaria en las revistas de mayor entidad científica en nuestro país. Presencia que presenta cuatro etapas bien definidas en el estudio de Baratas Díaz: en la primera, desde 1880 hasta 1892 , los trabajos micrográficos presentados son relativamente escasos, destacando los de Joaquín María Castellarnau y de Llopart (1848-1943) sobre organografía vegetal y microscopía, y los de Salvador Lo Bianco y Manuel Cazurro y Ruiz (1865-) sobre prácticas y observaciones histológicas de animales marinos. Estos tres autores estaban ligados o habrían de estarlo en un futuro inmediato a la Estación Zoológica de Nápoles. En esta época también aparecieron trabajos sobre neurohistología de José Madrid Moreno, que amplió estudios en Bolonia.

Un segundo momento, que abarcaría de 1892 a 1897, presentó, a diferencia de la dispersión de la primera etapa, un carácter monotemático: 
La época de Santiago Ramón y Cajal

la histología del sistema nervioso. El autor más prolífico, casi exclusivo, fue Santiago Ramón y Cajal -se incorporó a la Sociedad en junio de 1892, tras su llegada como catedrático de Histología y Anatomía Patológica de Madrid-, quién publicó trabajos sobre anatomía microscópica de diversos centros nerviosos. Incorporado a la Cátedra de Histología y Anatomía Patológica de la Universidad Central en 1892, Cajal utilizó los Anales -ver recopilación de A Baratas y B Fernández- y como vehículo para la difusión de sus trabajos; ello, en unos años en los que ni su situación económica ni la ausencia de reconocimiento entre sus conciudadanos, le permitían disponer de su propia revista. La aparición, en 1896, de la Revista Trimestral de Micrografía, continuada a partir de 1901 con los Trabajos de Laboratorio de Investigaciones Biológicas, dotó a Ramón y Cajal de un marco específico en el que presentar sus trabajos y limitó cuantitativa y cualitativamente la aportación cajaliana a la Sociedad.

En el contexto de ese "segundo momento" en las publicaciones de la Sociedad Española de Historia Natural, ingresaría Ramón y Cajal en la Real Academia de Ciencias Exactas, Físicas y Naturales; ello, no sin vencer ciertas dificultades. En la Sesión general del día treinta de octubre de 1895, inaugural del curso Académico de 1895 a 96, se daba cuenta:

«del fallecimiento del Académico electo, Excmo Sr Don Manuel $M^{a}$ José de Galdo, ocurrido, tras muy larga y penosa enfermedad, el $18 \mathrm{de} J \mathrm{~J}$ lio último. $Y$ después de lamentar tan triste suceso-recoge el Acta correspondiente-, de conformidad con lo que para tales casos disponen los Estatutos, se acordó declarar vacante la plaza que en la Sección de Ciencias Naturales estaba para el mismo Sr. Galdo destinada, y que de oficio se comunicase el acuerdo á la Sección, para que ésta, por los trámites de reglamento, procediese á proponer á la Academia el modo de llenarla, en los términos que más convenientes consideraser

El día 31 de octubre de 1895, el Secretario general, Miguel Merino y Melchor, oficiaba al Secretario de la Sección de Ciencias naturales -Don Daniel de Cortázar y Larrubia - instándole a cubrir la vacante (Medalla $\mathrm{n}^{\circ}$ 17) producida por el fallecimiento del Académico electo Don Manuel María José de Galdo y López, Doctor en Ciencias y en Medicina. La Sección de Ciencias naturales celebró sesión extraordinaria a tal efecto el día ocho de noviembre, en la que se presentaron sendas propuestas a favor de dos candidatos. Una a favor de Pedro Ávila y Zumarán, Ingeniero de montes, firmada por el académico Máximo de la Paz Graells y a la que se adhiere el académico Máximo Laguna y Villanueva. La segunda, fir- 
mada por los académicos Julián Calleja Sánchez, Daniel de Cortázar y Larrubia, Justo Egozcue y Cia y Joaquín González Hidalgo, respaldaba la candidatura de Pedro Palacios, Ingeniero del Cuerpo de minas y Bachiller en Ciencias.

Tras la Sesión extraordinaria celebrada por la Sección de Ciencias naturales el día 18 de noviembre, el Secretario de la Sección de Ciencias naturales trasladaba al Secretario general de la Academia la propuesta «de dos naturalistas», siendo el orden de preferencia en primer lugar D. Pe dro Palacios y Sáenz, y en segundo lugar D. Pedro Avila Zumarán. Un suceso inesperado dio un vuelco a los acontecimientos. Ramón y Cajal comentaría años más tarde:

"... El segundo acontecimiento, muy lisonjero para mí, fué mi elección espontánea de miembro de la Real Academia de Ciencias, de Madrid. Esta designación tiene su anécdota, que referiré, porque honra mucho al patriotismo e independencia de la sabia Corporación. Uno de los más conspicuos académicos, a la sazón recién llegado de Berlín, contó a sus compañeros que el gran Virchow, entonces en todo el esplendor de su gloria, habiale sorprendido con una pregunta a que no pudo responder: "¿En qué se ocupa ahora Cajal? ¿Continúa sus interesantes trabajos? Confuso y algo avergonzado nuestro prócer académico de que en Berlín inspirara interés la labor de un español de quien él no sabía palabra, procuró, de regreso a la Península, satisfacer su curiosidad. Y de sus conversaciones con el sabio astrónomo D. Miguel Merino, el inolvidable secretario perpetuo, surgió el acuerdo de iniciar y defender mi candidatura para cierta vacante, a la sazón en litigio. Tengo, pues, el singular privilegio de ser académico a propuesta de $R$. Virchow y de D. Miguel Merino.»

El día 27 de noviembre se celebró Sesión ordinaria. En el Acta correspondiente puede leerse:

«... Para cubrir la plaza de Académico, vacante por fallecimiento del Sr Galdo, de conformidad con lo acordado por la Academia en la sesión general anterior, de 30 de Octubre, la Sección de Ciencias Naturales propuso luego, con todas las formalidades de Estatutos, en propuestas razonadas, que á continuación, literalmente copiadas, se insertan: En primer lugar, al Sr Don Pedro Palacios y Saenz, Ingeniero de Minas, agregado años há á la Comisión del Mapa Geológico de España, y distinguido botánico; 


\section{La época de Santiago Ramón y Cajal}

y, en segundo, al Sr Don Pedro Avila y Zumarán, Ingeniero de Montes $y$ antiguo Miembro Correspondiente de esta Academia: botánico bien conocido y ventajosamente reputado por sus trabajos; $y$ por muchos años profesor de diversas asignaturas en la Escuela especial del Cuerpo á que pertenece.

Y el Académico Sr Merino, haciendo uso del derecho de adicionar las propuestas de las Secciones, que el artículo 60 de los estatutos, concede, en casos como el de que se trata, á todos los académicos, presentó por escrito, $y$ en los términos que también a continuación se copian, la candidatura, para la mencionada plaza vacante, del Dr. Don Santiago Ramón y Cajal, Catedrático de Histología de la Facultad de Medicina de Madrid.

... Aceptados por el orden de propuestas los tres candidatos-Palacios y Sáenz, Avila y Zumarán y Ramón y Cajal-, señalóse para la votación, ó votaciones que han de decidir la elección, previa citación bien explicita para ello y conforme los Estatutos previenen, el día 4 de Diciembre próximo, en sesión general extraordinaria. ...»

La propuesta firmada por el Secretario General de la Academia, Sr. Merino, a favor de D. Santiago Ramón y Cajal decía:

"El que suscribe tiene la honra de proponer á la Academia para ocupar la plaza vacante en la Sección de Ciencias Naturales por fallecimiento del Excmo. Sr. D. Manuel $M^{a}$ José de Galdo, al Catedrático de Histología en la Facultad de Medicina de Madrid, Dr. Don Santiago Ramón y Cajal.

Para los señores Académicos, á cuya consideración sometemos esta propuesta, constituiría casi una ofensa la declaración minuciosa de los merecimientos científicos y títulos de lata valía, verdaderamente extraordinarios, que reúne nuestro candidato, y que con poderosa eficacia recomiendan su admisión en la Academia.

Tan sólo por cumplir con una formalidad, en casos como el presente acostumbrada, aunque de ninguna manera necesaria, nos permitimos agregar a los escuetos renglones que preceden la lista, en su mayor parte impresa, de las ochenta producciones científicas, dadas a luz por nuestro candidato, á contar del año 1880, traducidas muchas inmediatamente al italiano y al francés, al inglés y al alemán, con elogio desusado de eminentes sabios de estos paises; y presentar, es una muestra, un ejemplar de su libro sobre el "Sistema nervioso en los animales vertebrados" - sintesis de sus admirables y variados estudios so- 


\section{Pedro García Barrero y Juan Fernández Santarén}

bre la estructura maravillosa de la médula espinal, cerebelo, corteza cerebral, mucosa y bulbo olfativo, lóbulo óptico y retina, sistema del gran simpático, plexos nerviosos intestinales, de aquellos seres - traducido al francés en el año corriente, y a estas fechas, dice el traductor Dr. Azoulay, mas difundido y mejor apreciado en Francia que en España. Con leer la sección de Bibliografía, que completa este trabajo, basta para conocer lo que vale el Dr. Cajal, y el honroso puesto que ocupa en Europa entre los más sutiles y famosos investigadores de la composición intima, atómica casi, y asombroso funcionamiento de la fibra orgánica animal.

$Y$, sin embargo, del sobresaliente mérito de tan perspicaz observador de los mas recónditos fenómenos del mundo físico y sagaz intérprete de las causas de donde emanan y efectos que á su vez producen, tarde hubiéramos tenido acaso exacto conocimiento, si no nos hubiese llegado la gloriosa revelación del extranjero. Tanto que como escribe un preclaro médico español, otra de nuestras mas indiscutibles y justamente celebradas eminencias científicas, raya en asombroso que la Real Sociedad de Londres y la Universidad de Cambridge hayan tenido que otorgar entusiasmadas el título de sabio al profesor Cajal, para que España atónita se entere de que andaba trasconejado un verdadero sabio entre nosotros.

Pues, aunque mi opinión nada valga ni signifique, paréceme a mi que no menos sorprendente o extraño sería que a tan ilustre cuanto modesto profesor se le recogiese, o empañase cuando menos, aquel título, cerrándole las puertas de esta casa, o deteniéndole inconsideradamente en sus umbrales. Por eso, creyendo favorecer así los intereses de la Academia, - único móvil á que en esta ocasión obedezco, propongo se le abran aquellas puertas de par en par, y se le honre y nos honremos de la única manera a nuestros alcances: acogiéndole sin vacilar entre nosotros y tributándole con esto, en representación de la ciencia patria, merecido aplauso por sus triunfos en el extranjero. Miguel $\mathrm{Me}$ rino. Madrid 27 de noviembre de 1895."

El dos de diciembre el Secretario de la Real Academia de Ciencias firmaba la convocatoria de una sesión extraordinaria a celebrar el día cuatro de diciembre. La plaza quedó vacante al no conseguir el candidato con más votos (Sr. Ramón y Cajal), en segunda votación, los quince necesarios para ser elegido. El día nueve de diciembre se procede a la convocatoria de una nueva sesión extraordinaria el miércoles día once. Sesión que contó con la presencia de un académico más ( 23 frente a los 22 del 
día cuatro); académico (Sr. Fernández Vallín) cuya presencia pudo ser decisiva en la elección de Ramón y Cajal como electo Académico Numerario. Puede intuirse que la elección de Cajal se debió al apoyo de las Secciones de Exactas y de Ciencias Físico-Químicas, y no de la Sección de Naturales. Tras contestar al requerimiento del Secretario de la Corporación, se confeccionó la hoja de «Antecedentes de los Sres. Académicos de Número y de los Corresponsales Nacionales y Extranjeros, necesarios para la historia de la Corporación».

El cinco de diciembre de 1897 ingresaba Ramón y Cajal en la Real Academia de Ciencias Exactas, Físicas y Naturales. En ese momento, tres Académicos lo eran electos y 32 estaban en posesión de la Medalla correspondiente; entre estos, dos perduraban en sus cargos Académicos desde la Fundación de la Real Academia en 1847. En ese momento, los Académicos eran, mayoritariamente, ingenieros. La Junta Directiva la formaban Cipriano Segundo Montesino y Estrada (Presidente), Mariano de la Paz Graells (Vicepresidente), Miguel Merino y Melchor (Secretario perpetuo), Ricardo Becerro de Bengoa (Vicesecretario), Julián Calleja y Sánchez (Tesorero), Joaquín González Hidalgo (Contador) y Eduardo Saavedra y Moragas (Bibliotecario). El Discurso de recepción de D. Santiago - Fundamentos Racionales y Condiciones Técnicas de la Investigación Biológica»- fue contestado por D. Julián Calleja y Sánchez.

"La redacción del discurso de ingreso, ocurrida en 1897, dióme ocasión de exponer-escribió Cajald-, ex abundantia cordis, algunas reglas y consejos destinados a despertar en nuestra distraida juventud docente el gusto y la pasión hacia la investigación científica. Puse especial empeño en hacer amables y atractivas las tareas del laboratorio, y para lograrlo empleé un lenguaje llano, sincero y rebosante de entusiasmo comunicativo $y$ de ferviente patriotismo. Y el éxito superó a mis esperanzas. Tan lisonjera acogida halló mi fogosa arenga en el público universitario y en la prensa, que, agotada rápidamente la tirada oficial del discurso, mi excelente amigo el Dr. Lluria, supliendo mi dejadez, estimó necesario reeditarla por su cuenta, destinando generosamente la nueva y copiosísima tirada a ser gratuitamente distribuida entre los estudiantes $y$ diversos centros de enseñanzoor.

El Discurso de recepción de D. Santiago $\leadsto$ Fundamentos Racionales y Condiciones Técnicas de la Investigación Biológicor- al que contestó D. Julián Calleja y Sánchez, fue inmediatamente publicado por el autor -tras una primera reimpresión a costa del Dr. Lluria «para regalarlo a los estudiantes y a los aficionados a las tareas de laboratorion- con el título «Reglas y Consejos sobre Investigación Científica (Los Tónicos de la 
Voluntad). Libro consagrado a la juventud españolo». "El libro actual es una reproducción, con numerosos retoques y desarrollos, de mi discurso de ingreso en la Academia de Ciencias Exactas, Fisicas y Naturales,, dice el autor en el prólogo. Las numerosísimas ediciones por diferentes editoriales han hecho de Los Tónicos de la Voluntad un texto clásico y un bestseller.

Retornando a la Real Sociedad de Historia Natural, en una tercera etapa, entre 1897 y 1921, el rango de autores de trabajos histológicos en la Real Sociedad se amplió de manera considerable. Las principales aportaciones se debieron a José Madrid Moreno, Salustio Alvarado, Emilio Fernández Galiano y Manuel Sánchez. Fundamental en este periodo es la activa y mayoritaria presencia de licenciados en Ciencias Naturales como autores de trabajos de Histología y Morfología microscópica; ello permite afirmar -señala Baratas Diaz-que en las primeras décadas del siglo XX esta disciplina tuvo su establecimiento definitivo, en su vertiente investigadora, entre los naturalistas españoles, quienes encontraron en las publicaciones de la Real Sociedad un vehículo idóneo para la difusión de sus estudios. Pero este predominio de los naturalistas no excluyó las aportaciones de otros colectivos profesionales como médicos (los hermanos Ramón y Cajal, Julián Calleja), veterinarios (Antonio Gallego) o ingenieros de montes (el mencionado Castellarnau). Esta diversidad de autores y de formaciones profesionales dio a los trabajos micrográficos publicados por la Real Sociedad una variedad temática de la que careció en la etapa inmediatamente anterior. Entonces, los trabajos de Histología y morfología microscópica animal se ocuparon menos del sistema nervioso, apareciendo estudios sobre la división celular.

La cuarta y última etapa comenzó en 1921 alcanzando hasta 1936. En ella, el autor más notable fue Pío del Rio Hortega (1882-1945), formado en el laboratorio de Achúcarro. Nicolás Achúcarro Lund (1880-1919) estudió en Marburgo y Madrid, asistiendo al laboratorio que fundaron $\mathrm{Si}$ marro y Juan Madinaveitia (Jefe del Servicio de Patología General del Hospital Provincial de Madrid). Una vez Licenciado, Achúcarro amplió estudios en París, con el neurólogo Pierre Marie; Florencia y Munich donde trabajó con Kräpelin y con Alois Alzheimer. Tras dos años en EE.UU, organizando y dirigiendo -por recomendación de Alzheimer- el laboratorio anatomopatológico del Manicomio Federal, regresó a España afincándose en el Hospital Provincial de Madrid. En 1912, La Junta de Ampliación de Estudios encargó a Achúcarro la organización de un Laboratorio de histopatología del sistema nervioso, que posteriormente formaría parte -como una Sección- del Instituto de Investigaciones Biológicas que di- 
rigía Cajal. En el laboratorio de Achúcarro, situado en el Museo de Historia Natural, se formaron Sacristán, Lafora, Gayarre, Calandre, Jiménez de Asúa y Pío Hortega.

«Por la importancia de sus contribuciones científicas y la repercusión internacional de su obra, Pío del Rio Hortega es -comenta López Piñero-, después de Cajal, la figura más destacada de la llamada Escuela Histológica Española». Formado en Valladolid, colaboró en el citado Laboratorio de Histopatología dirigido por Achúcarro. Luego marchó a París, Berlín y Londres, para regresar a Madrid en 1915. A la muerte a Achúcarro quedó al frente del Laboratorio. Tras su traumática salida del Laboratorio de Investigaciones Biológicas por un enfrentamiento con Ramón y Cajal, del Rio Hortega encontró en las publicaciones de la Sociedad un medio en el que dar a conocer sus trabajos científicos. En el Boletín y en las Memorias publicó Don Pío algunos de sus más importantes trabajos sobre oligodendroglía y microglía. Y su incorporación como autor habitual determinó, asimismo, la presencia de sus numerosos discípulos: Isaac Costero, Juan M. Ortiz Picón, Manuel López Enríquez, Felipe Jiménez de Asúa o Urtubey.

Miembros de la Sociedad Española de Historia Natural eran la práctica totalidad de los profesores de Ciencias Naturales de la universidad española, los investigadores del Museo de Ciencias Naturales, del Real jardín Botánico y no pocos profesores de enseñanza media. Es comprensible, por tanto, el interés que la Sociedad puso, una vez su situación institucional se hubo consolidado, en las cuestiones educativas y de fomento de la actividad científica. Además, proponían modificaciones puntuales en el régimen académico (reforma del mecanismo para la obtención del doctorado, creación de becas para estudios e investigaciones en centros extranjeros, etc.) y un nuevo plan de estudios, más específico y de mayor carácter práctico y experimental que el entonces en vigor. Así, en la sesión del 13 de enero de 1886 de la Sociedad Española de Historia Natural, el señor Presidente -don Antonio Machado Núñez- presentó: .

«una exposición suscrita por muchos amantes de las ciencias naturales, proponiendo las bases principales que podrian tenerse presente si se desea procurar actualmente en lo posible el desarrollo de las mismas en España y la urgente reforma de los métodos de su enseñanza. Aceptada por todos los presentes la idea de que en principio los socios tenian un alto interés científico en coadyuvar á los deseos de los que firmen el citado documento, se abrió discusión para acordar la forma que podria verificarse, tomando parte en ella los Srs. Presidente, Vice- 
presidente, Bolivar, Perez Arcas y Vilanova y se resolvió que los Srs. Machado y Martinez, como Presidente y Secretario, suscribiesen la exposición, haciendo constar que lo hacian por acuerdo de la Sociedad. Se acordó tambien insertar en las actas la exposición, que es la siguiente: Al Excmo. Sr. Ministro de Fomento. Excmo. Sr.: Los que suscriben, amantes de las ciencias naturales é interesados en su progreso $y$ desarrollo, á V. E., con el más profundo respeto, elevan las siguientes consideraciones: La enseñanza de las ciencias naturales en España es en extremo deficiente por causa de la organización incompleta y anticuada de los estudios, así como tambien por dominar en ella el carácter teórico sobre el práctico y experimental que permite á los alumnos familiarizarse con el empleo de los diferentes medios y procedimientos que las exigencias de la ciencia moderna hacen de todo punto indispensables. Nótase al propio tiempo la falta de un centro de investigación que contribuya en grande ó pequeña parte al adelantamiento de la ciencia; y si España no permanece por completo apartada del movimiento científico europeo, débese en gran manera, por lo que á los ciencias naturales se refiere, á una Sociedad de carácter puramente privado, la Sociedad española de Historia Natural, y á la decidida y entusiasta voluntad de algunas personas siempre en lucha con la escasez de recursos y la falta de colecciones y medios convenientes. ... Quizá no exista hoy el personal suficiente con el grado de educación necesario, ni tampoco el material indispensable para plantear grandes reformas, entre las que debieran contarse: $1^{\circ}$, el construir el Museo de Ciencias naturales en un centro independiente con personal propio $y$ dedicado tan sólo á la investigación científica, por ser el carácter docente y universitario que hoy tiene, impropio de esta clase de establecimientos: de analogía con lo que sucede en los demás países, y áun en el nuestro, siendo de ello un excelente ejemplo el Observatorio astronómico, el Instituto geográfico y la Comisión del mapa geológico; $2^{\circ}$, la ampliación hasta la licenciatura ó la creación en las que faltaren de las enseñanzas que se dan en varias, ya que no en todas las universidades de provincia, y lograr que en los institutos domine el carácter práctico y experimental sobre el teórico y expositivo; $3^{\circ}$, la fundación de estaciones zoológicas en diferentes puntos de nuestras costas; y $4^{\circ} y$ último, la creación de misiones y viajes científicos encaminados á la exploración, en primer lugar de nuestro suelo y el de nuestras posesiones en Ultramar, y más tarde de otras regiones del globo ... Para concluir, á fin de que el Museo de Historia natural de Madrid, en el que se dan las asignaturas especiales de la seccion de ciencias naturales, 
pueda completar sus laboratorios, ... deberia aumentarse la consignación que le esta asignada (consignación por extremo mezquina si se compara con la que disfrutan establecimientos análogos de otros países), y fijar en los presupuestos taxativamente la cantidad que deban percibir cada uno de los que componen el Museo de Ciencias, es decir, el Gabinete de His toria natural y el Jardín Botánico. Estas son, Excmo. Sr., las razones que impulsan á los que suscriben á desear la aplicación de las reformas indicadas, por creer firmemente que en ellas va envuelto el progreso y el de sarrollo de las ciencias naturales en España, como lo reclaman de consuno su pasado, en el que brillaron San Isidoro de Sevilla, Azara, Asso, Rojas Clemente, Cavanilles, Lagasca y tantos otros ilustres naturalistas, y su presente si ha de aspirar alguna vez á la vida científica en su fase hoy dominante. Por todo lo cual á $V$. E. Suplican se digne tener en cuenta en su elevado criterio las consideraciones expuestas, $y$ aceptar el adjunto proyecto para la reforma de las ciencias naturales en España. Dios guarde á V. E. Muchos años. Madrid 24 de diciembre de 1885. Antonio Machado Núñez; Francisco de P. Martinez y Saez; Odon de Buen; F. Qui roga; Ignacio Bolivar [y 97 firmas más]. Por acuerdo de la SOCIEDAD ESPAÑOLA DE HISTORIA NATURAL, El Presidente, Antonio Machado Núñez.- El Secretario, Francisco de P. Martinez y Saez.

Bases para la reforma de la enseñanza de las Ciencias naturales. ASIGNATURAS QUE DEBEN CONSTITUIR LA SECCION DE NATURALES DE LA FACULTAD DE CIENCIAS. Periodo preparatorio.- ... Licenciatura,- ... Doctorado.-... La enseñanza de todas las asignaturas superiores será práctica y con excursiones. Para aspirar á los grados de licenciado y doctor en la sección de naturales de la Facultad de Ciencias, una vez aprobadas las asignaturas correspondientes, se exigirá presentar una Memoria original de investigación propia, sobre un punto de libre elección. Los experimentos y trabajos necesarios para la realización de esa Memoria de llevarán a cabo en los laboratorios del Museo de Historia natural. ... Madrid 24 de diciembre de 1885».

Respecto del cúmulo de asignaturas de la licenciatura en Ciencias naturales se propuso la sustitución de algunas asignaturas: Cosmografía por Uranografía y geografía; Dibujo lineal por Dibujo aplicado a las Ciencias naturales; Histología por Criptogamia, Antropología y Embriología comparada, y se indicaba la conveniencia de asistir a algunas lecciones de técnica microscópica.

Pero la actividad de la Sociedad a favor de la reforma de la enseñanza de las Ciencias Naturales no se limitó a la redacción de manifiestos o 
exposiciones a las autoridades administrativas. También se ocupó la Sociedad de la enseñanza de las Ciencias Naturales en los primeros grados de escolarización y en las Escuelas Normales, proponiendo una serie de medidas para mejorar el nivel formativo de los futuros profesores y planteando mecanismos para ampliar los conocimientos del profesorado ya en ejercicio. Por todo ello, al inicio del siglo XX, la Sociedad Española de Historia Natural había jugado un importante papel presentando ante las autoridades políticas propuestas para el fomento de las Ciencias Naturales en nuestro país, que iban desde la reforma de las enseñanzas al planteamiento de modernas instituciones científicas.

\section{c. La Institución Libre de Enseñanza y la reforma educativa}

Sus antecedentes entroncan con la presentación por una Junta nombrada por la Regencia, en las Cortes reunidas en Cádiz el nueve de septiembre de 1813, de un «Informe de la Junta creada por la Regencia para proponer los medios de proceder el arreglo de los diversos ramos de instrucción pública". El informe, redactado por el poeta Quintana, indicaba las bases generales de la enseñanza que «debe ser igual y completa; universal o extendida a todos los ciudadanos; uniforme; en lengua castellana, evitando ese guirigay bárbaro llamado latín de escuelas; pública, gratita y libre». En el plan Quintana se dibuja el ideal centralizador sobre el que Jovellanos propugnó una Universidad Central - una gran Universidad en Madrid -, que quedaría instalada en el local del Colegio Imperial el siete de noviembre de 1822; el presidente de la Dirección General de Estudios, don Manuel José Quintana, pronunció el discurso de inauguración.

El plan Quintana fue reemplazado, en octubre de 1824, por el del padre Martínez, obispo de Málaga, y refrendado por Francisco Tadeo Calomarde (1773-1842). La Dirección General de Estudios fue reemplazada por la Inspección General de Instrucción Pública. El nuevo Plan daba completa uniformidad a la enseñanza y organización de las Universidades, destruyendo lo poco que quedaba de autonomía universitaria. Los años del ministerio de Calomarde se conocen como la ominosa década de Calomarde, siendo proverbial la frase ni en tiempo de Calomarde para ponderar la arbitrariedad de su gobierno. Ello, junto con las vicisitudes de la primera guerra carlista llevaron a la ruina universitaria. Un Real Decreto de 1845 dio un nuevo Plan General de Enseñanza para todo el reino; plan más centralizador que el del año 1824 y que ostentaba el 


\section{La época de Santiago Ramón y Cajal}

nombre de don Antonio Gil de Zárate, director de Instrucción Pública. El nuevo plan -comenta A Jiménez- llevaba a extremos aún más exagerados la centralización y secularización de la enseñanza y no admitía en ella más dirección que la del Gobierno, fiel reflejo de los principios de soberanía del Estado y sus instituciones gubernamentales que los tiempos modernos habían heredado de las monarquías absolutas. Y aún cristalizó más esta tendencia en la famosa Ley de Instrucción Pública -Ley Moyano- de 1857; ley que perduraría hasta 1900. Sin embargo, aquel mismo año -1857- representó el inicio de un movimiento interno de reforma. Don Julián Sanz del Río -profesor de Historia de la Filosofía de la Facultad de Filosofía y Letras- formulaba la definición y principios del racionalismo armónico y pronunciaba el discurso correspondiente a la sesión solemne de inauguración del año académico 1857-1958 universitaria; un discurso impregnado de principio a fin de un decidido espíritu reformista que produce un grande y general impacto. En 1860, coincidiendo con la publicación del Sistema filosófico y del Ideal de la $\mathrm{Hu}$ manidad para la vida, de Krause y traducidas por Sanz del Río, aparece la revista de los neocatólicos y antikrausistas: El Pensamiento Español, Fundado por Navarro Villoslada, y los krausistas contraatacan. La Iglesia acusa el peligro y la Sagrada Congregación del Índice incluye El Ideal de la Humanidad en dicho Índice de lecturas prohibidas en 22 de septiembre de aquel mismo año. Años después:

«Por Real Orden de 31 de mayo último (1867) se mandó al doctor don Julián Sanz del Río, Catedrático de la Facultad de Filosofía y Letras de la Universidad Central en concepto de autor y editor de un libro titulado Ideal de la humanidad para la vida, por Krause, con introducción y comentarios, impreso en Madrid en 1860, y condenado por la Suprema Autoridad de la Iglesia en 26 de septiembre de 1865 ... después de madurado examen y considerando que no puede ni debe continuar en el magisterio público de las ciencias quien habiendo tenido la desgracia de que su escrito se prohíba y ponga en el indice de la doctrina reprobada, no se apresura a someterse al juicio de la Iglesia, maestra de la verdad, antes bien rehuye con fútiles pretextos la franca explicación que el Gobierno tiene derecho a exigir en su calidad de protector de los intereses de la educación, ha evacuado su dictamen de 26 de octubre, proponiendo la separación de dicho profesor ... y mandar por tanto que el mencionado profesor sea dado de baja en el escalafón de su clase. ... Madrid, 31 de diciembre de 1867. Orovio [Manuel Orovio y Echagüe (1817-1883) sucedió a Alcalá-Galiano en la 
cartera de Fomento - gobierno presidido por Narváez - tras la trágica noche de San Daniel de 1865]. Sr Director General de Instrucción Pública».

El «auto de fe» también incluyó a Lázaro Bardón y Manuel José de Galdo -cuyas disculpas fueron bien acogidas por el obispo auxiliar de Madrid-Alcalá-, a Fernando de Castro y a Nicolás Salmerón Alson que fue apartado de su cátedra. Francisco Giner de los Ríos «protestó respetuosamente" por el menoscabo de la consideración debida al Cuerpo universitario - el gesto de Giner le convirtió de golpe en el más acendrado defensor de la llamada libertad de la ciencia-. La protesta supuso que el Rector dejara suspenso, en el acto, a Don Francisco.

En septiembre de 1868 triunfa la revolución -La Gloriosa-; Manuel Ruiz Zorrilla ocupa la cartera de Fomento, nombra a José Echegaray Director General de Instrucción Pública y destituye a Orovio. Un decreto de 21 de octubre establecía la libertad de enseñar, declarando en su artículo quinto: «La enseñanza es libre en todos sus grados y cualquiera que sea su clase», y en el sexto añadía: "Todos los españoles quedan autorizados para fundar establecimientos de enseñanza». Ese mismo mes se reponen en sus Cátedras a los sancionados. Los krausistas se imponen en la Universidad; Fernando de Castro es nombrado Rector de la Universidad Central, y el día 10 de enero de 1869 aparecía el primer número del Boletín-Revista de la Universidad de Madrid de la mano de Castro, Uña, Salmerón y, sobre todo, de Giner quién escribió una serie de artículos titulados genéricamente «La futura Ley de Instrucción Pública» «la educación del hombre en la verdad»-que debería modificar la Ley Moyano de 1857.

En mayo de 1874 moría Fernando de Castro y comenzaba el declive revolucionario. En febrero de 1875 un Real decreto y una Circular de Fomento restablecían la legislación anterior a 1868 y, también a Orovio; con ello, la Universidad europeizada sufre un radical retroceso. Desde la primera cuestión universitaria a la segunda solo transcurrieron nueve años; esta vez los catedráticos reaccionan y están dispuestos a renunciar a sus cátedras si la Circular de Orovio se cumple. El dos de abril de 1875 ingresaba Giner de los Ríos en el Castillo de Santa Catalina, prisión militar gaditana. En julio se separa de sus cátedras a Giner, Salmerón y Azcárate. Giner y Salmerón se lanzan la idea de unos «estudios libres».

El 15 de febrero de 1876, Alfonso XII abrió las Cortes Constituyentes; Canovas presidía el Consejo de Ministros, quién leyó el proyecto de Cons- 


\section{La época de Santiago Ramón y Cajal}

titución ante las Cortes el 27 de marzo. El artículo 13 concedía a los españoles el derecho de emitir libremente sus ideas y opiniones; y el artículo 24 prescribía que todo español podrá fundar y mantener establecimientos de instrucción o educación. El Imparcial del 24 de mayo, bajo el epígrafe «La Universidad libre», publicó un suelto:

«... Reunidos en Junta organizadora los señores don Laureano Figuerola, don Eugenio Montero Ríos, don Segismundo Moret y Prendesgast, don Nicolás Salmerón y Alonso, don Francisco Giner de los Ríos, don Augusto González de Linares, don Gumersindo de Azcárate, don Laureano Calderón, don Juan Antonio García Labiano y don Jacinto Messia, redactaron en 18 de marzo último el proyecto para la creación de un establecimiento de enseñanza libre .....

El proyecto universitario de la Institución pretendía albergar estudios secundarios y superiores:

«La Institución establecerá, según lo permitan las circustancias y los medios de que pueda disponer: $1^{\circ}$. Estudios de cultura general y profesionales, con los efectos académicos que les conceden las leyes del Estado. $2^{\circ}$. Estudios superiores cientificos. $3^{\circ}$. Conferencias y cursos breves de carácter y científico, ya populam.

Entre los estudios superiores impartidos por la Institución destaca la asignatura Morfología natural, impartida por Augusto González de Linares (1845-1904), durante los Cursos académicos 1877-78 y 1878-79. Linares representó la síntesis krauso-positivista en la Institución, aunque la mayoría (Salvador Calderón, Joaquín Costa, Lázaro Ibiza, José Madrid Moreno, Luis Simarro) de los institucionistas se identificaron con el positivismo.

Desde su inicio la Institución pretendió crear laboratorios dotados de material científico - gabinete de Historia natural, laboratorio de Química, gabinete micrográfico - utilizados para la enseñanza práctica de la ciencia. Así, el Boletín de la Institución (Tomo I, 1877) incluía una nota anexa al "cuadro de asignaturas para el Curso 1877-78»:

«1 ${ }^{\circ}$. Todas las clases correspondientes a la Facultad de Ciencias tendrán carácter experimental ... $2^{o}$. En las clases de Física y Química se destinarán tres lecciones semanales a trabajos de laboratorio. $3^{\circ}$. En las clases de Historia natural se consagrará el tiempo conveniente a prácticas ...». 


\section{Pedro García Barrero y Juan Fernández Santarén}

La Institución fue pionera en la enseñanza práctica de la ciencia; nació con la pretensión de convertirse en una «Universidad libre», pero limitaciones económicas y condicionantes pedagógicos terminaron por hacer evolucionar la Institución hacia un establecimiento de primera y segunda enseñanza. No obstante, a partir de 1881 la Institución se constituyó en un "gabinete de estudios sobre la reforma educativa» en todos sus grados. A lo largo de las dos últimas décadas del siglo XIX, hombres vinculados a la Institución realizaron propuestas concretas para la re forma de la enseñanza universitaria (reforma del doctorado, becas en el extranjero, aumento de la dotación material y personal, etc.). Las propuestas institucionistas planteaban, además, la necesidad de establecer un nuevo organismo encargado de poner en práctica dichas medidas. Este organismo, al que denominaban "escuela de altos estudios» o "escuela de estudios superiores», debía ser el responsable de la política de becas y la gestión de laboratorios científicos, y permitiría la creación de un nuevo cuerpo profesoral responsable a su vez de la renovación universitaria. El objetivo último de esta nueva institución, claramente inspirada en un organismo homónimo francés, la Escuela Práctica de Altos Estudios (École Pratique des Hautes Études), era configurar un nuevo marco universitario, con más funciones que las codificadas en la ya obsoleta legislación isabelina. La nueva universidad, en el ideario institucionista, debía ser un centro de formación profesional, de investigación científica y, sobre todo, centro educativo. No sólo había que habilitar para el ejercicio profesional, había que fomentar la reflexión y el estudio científico como mecanismo básico en la formación de los ciudadanos de un nuevo país.

\section{d. Estación de Biología Marítima de Santander}

Si hay un marco institucional en el que las propuestas de los dos colectivos hasta ahora reseñados (naturalistas e institucionistas) se funden es, sin duda, la Estación de Biología Marítima de Santander. Desde principios de la década de 1880, naturalistas vinculados a la Sociedad y al Museo habían promovido la concesión de becas de estudio en la Estación Zoológica de Nápoles con la pretensión última de formar algún especialista capacitado para dirigir un establecimiento similar en las costas españolas. También diversos naturalistas habían utilizado el Boletín de la Institución Libre de Enseñanza para señalar la conveniencia de crear un centro de estudios marinos en nuestras costas. 


\section{La época de Santiago Ramón y Cajal}

En la sesión del siete de junio de 1882, el señor Vilanova, catedrático de Paleontología de la Facultad de Ciencias de Madrid y socio fundador de la Sociedad Española de Historia Natural, informaba ante ésta de un viaje científico por varios países europeos en el que visitó la Estación Zoológica de Nápoles:

"... y pongo fin al desaliñado relato apuntando el pensamiento que me anima de que participe un dia no lejano nuestra querida patria de los beneficios de aquel sorprendente centro de enseñanza, á cuyo fin espero fundadamente me secundareis todos, y en especial los que, en su calidad de individuos de la Junta de profesores del Museo, podéis influir en que ésta tome la iniciativa en la petición al Gobierno para que éste designe algún pensionado para estudiar esta Estación zoológica napolitana, de la que tantos y tan sorprendentes resultados pueden y deben con harto fundamento esperarse. ...

-Para llenar los deseos manifestados por el señor Vilanova respecto á la fundación de una Asociación para el adelanto de las ciencias en España, á propuesta del señor Presidente la Sociedad acordó la inserción en las Actas de una nota en que se dé á conocer el pensamiento, coadyuvando así por el momento á los fines que se propone el señor Vilanova».

La petición de pensiones realizada por la Junta de profesores del Museo de Ciencias - de la que Vilanova era secretario- resulto en la concesión de una comisión a favor del ingeniero de montes Joaquín $\mathrm{M}^{\mathrm{a}}$ de Castellarnau para ampliar sus estudios en la Estación napolitana. Tras la breve estancia de Castellarnau en Nápoles se interrumpió el envío de pensionados y, en 1884, Vilanova y la Junta de Profesores del Museo insistieron de nuevo en la necesidad de dichas becas, cuyo objetivo último era formar algún naturalista capacitado para la organización y dirección de una estación de biología marina en las costas españolas. Desgraciadamente, estas propuestas fueron desoídas por las autoridades educativas. Por su parte, en el Boletín de la Institución Libre de Enseñanza se recogieron -apunta Baratas- diversos artículos de Salvador Calderón, Blas Lázaro Ibiza y otros, en los que se informaba de diversas campañas de exploración marina y se proponía la creación de «dos modestas estaciones Zoológicas, una situada en el litoral del Cantábrico y la otra en algún punto de la costa del Mediterráneo».

Paralelamente a estas propuestas, Augusto González de Linares, quién separado de su cátedra de Historia Natural en Santiago a raíz de 


\section{Pedro García Barrero y Juan Fernández Santarén}

la "cuestión universitaria» de 1875 se había integrado en la Institución Libre de Enseñanza, abandonó esta en 1880 ("diáspora institucionista») para incorporarse a la Sección de botánica del Museo de Historia Natural de París, desde donde escribió a Francisco Giner mostrando su satisfacción por los trabajos realizados. Con la llegada de los liberales al poder, la Dirección General de Instrucción Pública comisionó a González Linares por dos años, durante los que visitó el Museo de Historia Natural de Londres, y los Laboratorios marinos de Wimereux, Concarneau, Marsella y Nápoles. De vuelta a España, en 1883, fue comisionado de nuevo por el Ministerio de Fomento para «completar estudios sobre la fauna de los animales marinos inferiores de la costa cantábrica». Todas estas comisiones logradas gracias a las gestiones de Giner y al margen de las propuestas del Museo de Ciencias Naturales de Madrid, permitieron a González de Linares adquirir una notable formación en Biología marina y conocer la estructura y funcionamiento de algunas de las más importantes estaciones marítimas europeas disfrutó de diversas comisiones oficiales que le permitieron viajar por diversos laboratorios y estaciones marítimas europeas. Al crearse en Santander, por Real Decreto de 14 de mayo de 1886 - era Ministro de Fomento Eugenio Montero Ríos -, la Estación Marítima de Zoología y Botánica Experimentales, González de Linares puede considerarse director de facto del nuevo centro. El Real Decreto decía:

«Este laboratorio tiene por objeto: $1^{\circ}$. El estudio y la enseñanza dela fauna y flora de nuestras costas y mares adyacentes, asi como las cuestiones científicas enlazadas con aquellas. $2^{\circ}$. El de las aplicaciones prácticas de estos conocimientos al desarrollo de las industrias marítimas. $3^{\circ}$. La formación e incremento de las colecciones científicas de los museos y establecimientos de enseñanzor.

Sin embargo, si la Estación fue creada oficialmente en 1886, hasta 1889 no tuvo lugar su instalación y funcionamiento. González de Linares fue enviado a la estación napolitana, siendo nombrado oficialmente director a su regreso, en junio de 1887, cargo que ocupó hasta su muerte en 1904 -a González de Linares y hasta la Guerra Civil, le sucedieron José Rioja y Martín (1866-1945) y Luis Alaejos y Sanz (1876-1967) quién, en 1935, anunció a las autoridades locales la posibilidad de que el Centro se cerrara a causa de su mal estado de conservación y la falta de subvenciones por parte del Ayuntamiento y la Diputación-. A partir de 1887 comenzó la instalación definitiva de la Estación en la ciudad de Santander, 
y González de Linares pudo poner en marcha algunas iniciativas largamente pensadas durante su estancia en Nápoles. La iniciativa más relevante fue el establecimiento de una comisión interministerial-Ultramar, Fomento y Marina- para enviar naturalistas y oficiales de la Armada a la estación italiana. Se satisfacían así las propuestas previas de científicos e institucionistas: se fomentaba la creación de nuevos laboratorios (dignamente dotados), se establecían becas de estudio en centros extranjeros y la formación de oficiales de la Armada en cuestiones biológicas era un paso previo, e imprescindible, en el impulso de las expediciones oceanográficas.

La labor de González de Linares tuvo antecedentes -en Mariano de la Paz Graells-e iniciativas similares. Aunque hubo tentativas de crear un centro análogo en la ría de Arosa por Vila y Nadal, hubo que esperar -escribe Madariaga de la Campa- a 1905 para que apareciera la efímera Estación de Biología Marítima de África, creada en agosto de 1905 y al año siguiente, el Laboratorio de Baleares, dirigido por el profesor Odón de Buen, al que cabe considerar -continúa Madariaga- como padre de la oceanografía española. El Ministerio de Marina, por R.O. de febrero de 1908, creaba a su vez la Escuela de Zoología de Barcelona.

En la elección y seguimiento de los becados en Nápoles jugaron un importante papel González de Linares, como director de la Estación santanderina, Francisco Giner de los Ríos de la Institución, e Ignacio Bolívar, director del Museo de Ciencias y de la Sociedad Española de Historia Natural. Pero el programa de becas no se limitó a enviar a unos cuantos naturalistas; siguiendo un patrón grato al institucionismo, la selección fue muy personalizada y se tomaron medidas para garantizar la mínima formación previa del pensionado. También, en colaboración con el Museo de Ciencias Naturales, se diseñaron mecanismos que permitieron la reincorporación de alguno de estos becarios al tejido científico español. A lo largo de la década de 1890, acabado ya el programa de pensiones en Nápoles, se inició un plan de becas en la Estación santanderina.

A pesar de las dificultades de la Estación y los altibajos de este nuevo programa de becas, en estrecha colaboración con el Museo de Ciencias Naturales, la práctica totalidad de los naturalistas españoles de la última década del siglo XIX y la primera del XX realizaron cortas estancias en Santander. Muchos de ellos adquirieron allí conocimiento de las técnicas y prácticas micrográficas, otros encontraron tema y colecciones para sus tesis doctorales. Aunque sus responsables no realizaron una labor investigadora notable, la Estación se constituyó en una institución docente de primer orden. Dentro del esquema institucionista -debe re- 


\section{Pedro García Barrero y Juan Fernández Santarén}

saltarse la adscripción de González de Linares al grupo institucionista-, la Estación puede considerarse una «experiencia piloto» en la que se pusieron en práctica, a pequeña escala, medidas innovadoras: becas de estudio en el extranjero, control directo y minucioso de las actividades desarrolladas por los becarios, participación de especialistas en la selección de personal, medidas para el aprovechamiento posterior de los conocimientos adquiridos por los becarios, etc. Muchas de estas medidas, a mayor escala, se volverían a llevar a cabo en otro organismo público también promovido, indirectamente, por la Institución: la Junta para la Ampliación de Estudios e Investigaciones Científicas. Hasta 1914, año en el que la Estación pasó a depender del Instituto Español de Oceanografía -dirigido por Odón de Buen- pasaron un número importante de alumnos, entre otros: Antonio de Zulueta, Celso Arévalo -futuro director del Laboratorio de Hidrobiología de Valencia-, Antonio García Varela -que dirigiría el Laboratorio de Fisiología vegetal del real Jardín Botánico-, etc.

\section{e. Ministerio de Instrucción Pública y Junta para la Ampliación de Estudios}

No sería hasta 1900, tras la creación del Ministerio de Instrucción Pública, cuando se inició una amplia remodelación de los estudios universitarios. Antonio García Alix, primer ministro de Instrucción encargó a Ignacio Bolivar el proyecto de reforma de la Facultad de Ciencias y el Museo de Ciencias Naturales. La reforma diseñada por Bolivar introdujo una serie de medidas concordantes con las planteadas por la Sociedad Española de Historia Natural, modificando el plan de estudios, reorganizando el Museo de Ciencias Naturales, fomentando la enseñanza práctica, etc. Otra consecuencia capital para la ciencia española es la confluencia de intereses y la estrecha colaboración entre el institucionismo y los colectivos científicos del país. El institucionismo encontró en la clase científica sólido apoyo a sus propuestas de reforma universitaria -en las que la ciencia tenía un papel esencial- y los científicos encontraron un grupo de mayor proyección político-social, con más capacidad para conseguir la plasmación administrativa de sus intereses.

La pérdida de las colonias ultramarinas originó una profunda conmoción en el sistema de la Restauración. Consecuencia de la inesperada de rrota ante Estados Unidos fue la celebración en el Ateneo de Madrid, durante 1902, de un debate sobre "Oligarquía y caciquismo", organizado por Joaquín Costa Martínez, que se constituyó en un profundo examen 


\section{La época de Santiago Ramón y Cajal}

del sistema político de la Restauración y en foro de difusión de medidas para renovarlo en profundidad. Significativamente, la primera propuesta reformista planteada por Costa -antiguo miembro de la Institución Libre de Enseñanza- fue el «fomento intensivo de la enseñanza y de la educación por métodos europeos».

Inmediatamente antes del debate ateneísta, en 1899, Costa había convocado la Asamblea Nacional de Productores con la pretensión de constituir una fuerza política de carácter reformista. En las discusiones de la Asamblea se debatió un informe de Manuel Bartolomé Cossío titulado "Sobre la reforma de la educación nacional». Cossío planteó la necesidad de reformar el personal educativo, de conceder becas para ampliación de estudios en el extranjero, de introducir la enseñanza práctica en todos los grados del sistema educativo y especialmente en la universidad, de reformar el doctorado, etc. Cossío también se manifestó a favor de la «organización inmediata de una Escuela de estudios superiores, formada escogiendo las personas que reconocidamente han dado muestras de trabajo sólido, de investigación personal, en cualquier ramo; muy pocas. El trabajo sería exclusivamente de investigación, con poquísimos alumnos y muy escogidos.

Aunque el proyecto político que Costa pretendía propiciar se disolvió de manera casi inmediata, las propuestas pedagógicas planteadas, síntesis de las que el institucionismo había promovido durante las dos últimas. décadas del siglo XIX, sí alcanzaron una cierta relevancia en medios oficiales. En abril de 1900 se estableció el Ministerio de Instrucción Pública, segregando estas competencias de la cartera de Fomento. El primer titular del nuevo ministerio, el conservador Antonio García Alix, concibió las cuestiones educativas como básicas en el proceso de "regeneración» del país. A pesar de su corta estancia al frente del cargo, García Alix inició una reforma en profundidad de los planes de estudios universitarios y estableció mecanismos que permitieron implantar la enseñanza práctica en las facultades. Muy significativamente, estos planteamientos encontraron en Ignacio Bolívar y en la Facultad de Ciencias terreno abonado para prosperar. Ignacio Bolívar y Urrutia (1850-1944), quien como vimos tuvo un papel protagonista en el desarrollo de la Estación de Biología Marina de Santander, era miembro del Consejo de Instrucción Pública y sería, en breve, decano de la Facultad de Ciencias y director del Museo. Fue Bolívar el encargado de delinear los planes de estudios de las diversas secciones de la Facultad de Ciencias y plantear la reforma reglamentaria y funcional del Museo de Ciencias Naturales. Respecto de la sección de Ciencias Naturales de la Facultad de Ciencias, el plan de es- 
tudios aprobado se ajustaba a lo propuesto por la Sociedad Española de Historia Natural en 1886. La enseñanza práctica se introdujo, a título experimental, en algunas asignaturas de la Facultad de Ciencias. Los alumnos de dichas asignaturas debían abonar al matricularse una tasa complementaria en concepto de derechos de prácticas: con dicho dinero se esperaba completar un mínimo presupuesto para la adquisición de material e instrumentos. Esta medida se extendió posteriormente a la totalidad de las asignaturas de Ciencias y a las facultades de Farmacia y Medicina.

Otra innovación, introducida bajo el mandato de García Alix, fue la reforma del mecanismo para la obtención del grado de doctor. Al dictarse un nuevo reglamento de exámenes y grados en las universidades, se exigió a los candidatos al doctorado la elaboración de una tesis o memoria sobre un punto doctrinal o de investigación práctica elegido libremente, y que entregará manuscrita en el acto de solicitar el examen. Se formalizaba así una vieja propuesta de científicos e institucionistas. También se promovió la concesión de becas; en un primer momento se autorizó a profesores numerarios y supernumerarios a solicitar licencia con sueldo por espacio de un año para ampliar estudios en el extranjero, prometiendo una subvención adicional si los presupuestos lo permitían. En los años siguientes, nuevas disposiciones permitieron la incorporación al programa de licenciados y estudiantes de doctorado, se diseñaron nuevos mecanismos de elección y valoración, de reincorporación al sistema universitario, etc.

En suma, el primer Ministerio de Instrucción Pública inició una política de reforma de la enseñanza superior sin precedentes. Se adoptaron medidas, en muchos casos modestas o con carácter experimental, en la línea de lo que científicos e institucionistas habían planteado repetidamente. En los años siguientes, con otros políticos como responsables de la cartera de Instrucción Pública, la política reformista se continuó: se dictaron nuevas normas para becarios en el extranjero, se destinaron partidas presupuestarias para la adquisición de instrumental científico, se establecieron nuevos centros de investigación -Laboratorio de Investigaciones Biológicas-, etc.

Por entonces, la enorme figura de Cajal supuso una situación sin precedentes. La concesión, en 1900, del Premio Moscú con motivo del Congreso Internacional de Medicina impulsó la creación de un instituto de investigaciones. Francisco Silvela -Presidente del Gobierno-, Antonio García Alix -Ministro de Instrucción Pública- y Raimundo Fernández Villaverde -Ministro de Hacienda- se mostraron partidarios de la idea. 


\section{La época de Santiago Ramón y Cajal}

El 30 de agosto de 1900, los Ministerios de Hacienda, de Agricultura y de Obras Públicas sometieron al Consejo de Estado un informe sobre «la forma de conceder al sabio Dr. D. Santiago Ramón y Cajal el auxilio del estado":

«La forma en tal virtud más adecuada para cooperar oficialmente a la obra del doctor don Santiago Ramón y Cajal, sin menoscabar su independencia y libertándole, en cambio, de las dificultades que lleva consigo todo organismo de aquel carácter ... sería la de asignarle una subvención extraordinaria por una sola vez y otras más módica permanente, ambas con carácter puramente personal, sin exigirle otra justificación que la indispensable que espontáneamente aportase ...».

La influencia de la creación del nuevo laboratorio -designado «Laboratorio de Investigaciones Biológicas» e instalado provisionalmente en un hotel de la calle de la Vega y luego al Museo del doctor Velasco- sobre la tarea de Cajal fue muy importante. Tras la creación de la Junta para la Ampliación de Estudios, el Laboratorio se integró en ella, en 1920, como Instituto Cajal; Cajal siguió siendo su Director hasta su muerte en 1934.

Sin embargo, la culminación de la política reformista inaugurada tras el Desastre fue la creación de la Junta para la Ampliación de Estudios e Investigaciones Científicas (JAE) en 1907. La junta supuso la cristalización administrativa de la "escuela de estudios superiores» que los institucionistas habían propuesto en diversas ocasiones. A este respecto $\mathrm{Ca}$ cho Viu insiste en que "no fue la Junta "de" la Institución Libre de Enseñanza... Otra cosa es que la institución y Don Francisco Giner, personalmente, inspiraran su diseño y la elección de quienes iban a ponerla en marcha ...». Organismo autónomo, dependiente del Ministerio de Ins trucción Pública, formado por una veintena de investigadores y profesores de prestigio incuestionable, la junta fue la encargada de la concesión de becas en el extranjero y la gestión de laboratorios y seminarios; se constituyó, por tanto, en el instrumento de política científica más importante del primer tercio del siglo XX.

En la Exposición que el ministro Amalio Gimeno -ministro de Instrucción Pública en el gobierno liberal de Vega Armijo- hizo a S. M. Alfonso XIII en el R. D. 11/1/1907 (Gaceta de 18 de enero) por el que se crea la Junta para Ampliación de Estudios e Investigaciones Científicas, puede leerse:

"El más importante grupo de mejoras que pueden llevarse a la instrucción pública es aquél que tiende por todos los medios posibles a 


\section{Pedro García Barrero y Juan Fernández Santarén}

formar el personal docente futuro y dar al actual medios y facilidades para seguir de cerca el movimiento científico y pedagógico de las naciones más cultas, tomando parte en él con positivo aprovechamiento. Abandona el Estado en España esa función a las fuerzas aisladas del Profesorado y de la juventud sin ofrecer a ésta otros medios que los indispensables para la obtención de un título, ni otorgar a aquél sino una retribución que no puede alcanzar para viajes de estudio, ni siquiera para adquirir las revistas y los libros que aumenten su caudal de erudición. El problema de la formación del personal docente, intimamente enlazado con el fomento de los estudios científicos, lo han resuelto otros paises acudiendo a un remedio que, aun sin estar, como ya está, probado y reconocido, parecía siempre eficað).

Aunque se haya insistido en destacar -comenta Moreno González-el papel de la Junta respecto al fomento de la investigación científica, es manifiesto en el Decreto de creación, así como en el Reglamento posterior, que la preocupación más imperiosamente sentida por los promotores de la misma era elevar la calidad del profesorado. El principal medio elegido para llevar a cabo esta tarea fueron las pensiones; de hecho, por la importancia concedida a las mismas la JAE fue más conocida como «Junta de Pensiones». En cierto modo, el desarrollo científico era considerado como un medio -determinante e imprescindible, eso sí- para mejorar las enseñanzas. Otra cosa es cómo fue desenvolviéndose la operación que, sin ninguna duda, resultó considerablemente más ventajosa para la investigación científica en sí misma; acaso porque pudo organizarse con bastante autonomía a través de múltiples Institutos y Laboratorios.

El día 15 de enero, antes de que el decreto apareciese en la Gaceta, se celebró el acto de constitución de la nueva organización, resultando elegido Santiago Ramón y Cajal su presidente: José Castillejo y Duarte fue el secretario.. Pocos días después, pasaba el Gabinete a manos del conservador Maura, haciéndose cargo de la Cartera de Instrucción Pública Faustino Rodríguez San Pedro que, en los casi tres años de su mandato -escribe Sánchez Ron- hizo notar su presencia alicortando los vuelos con que, en su opinión, fue creada la JAE. De él escribiría Américo Castro: "La incultura de este hombre, unida al miedo de los conservadores hacia lo nuevo, pudo ser funesta para la Junta en sus primeros tiempos».

El Reglamento de la Junta fue publicado en la Gaceta el 26/6/1907 siendo ministro Rodríguez San Pedro con algunas limitaciones; una de las primeras manifestaciones de las resistencias que la JAE encontró a 


\section{La época de Santiago Ramón y Cajal}

lo largo de su historia. En 1917, Ignacio González Martí, catedrático en la Universidad Central y miembro de la Academia de Ciencias, pronunció el discurso inaugural «Estado de la enseñanza de la Física en las Universidades de España»- de la Sección de ciencias físico-químicas del VI Congreso de la Asociación Española para el Progreso de las Ciencias, y en el que dijo en relación con la Junta:

«Perfectamente acertada hubiéramos encontrado la creación de la Junta si las Universidades, colocadas en las condiciones de aquella, no diesen los mismos resultados, o si la capacidad productora de España en investigadores fuese suficiente, no sólo para llenar los laboratorios universitarios, sino para exigir otros destinados a las personas que, no deseando someterse a los planes docentes, estuvieran capacitadas para dedicarse a la investigación. ... Tal como ha sido creada la Junta constituye un agravio a la Universidad, a la que se declara impotente para obtener los resultados conseguidos por aquella, y cabe pensar, antes de declarar dicha impotencia, que si la segunda hubiera dispuesto de los medios de que la primera dispone, su estado no sería el que hoy es. El efecto externo, y nos alegrariamos de que así no fuese, es dividir a los catedráticos en dos castas, los puramente universitarios, para los cuales son las desconfianzas y las economias de Estado, y los adeptos a la Junta, para los que toda independencia y prodigalidad parecen pocas. Una vez constituida la Junta de Ampliación de Estudios tenía necesidad de justificar la utilidad de su labor y la de los laboratorios que creara, y el instinto de conservación condujo al personal a éstos adscritos a descuidar el trabajo en los suyos de la Universidad ... ¿ Es extraño, señores, que la Universidad mire con desconfianza y acaso con cierta hostilidad a esa Junta que hace cuantos esfuerzos puede para arrebatarle sus más preclaros hijos?."

$\mathrm{Al}$ año siguiente, la Junta recibía otra crítica sobre el marcado carácter centralista de la JAE; esta vez durante la sesión del día diez de abril del Segundo Congreso Universitario Catalán (7-14 abril 1918). Con todo, la Junta tuvo una destacada intervención en el desarrollo de la infraestructura necesaria para la investigación; en concreto, en la creación de centros de estudios y laboratorios., haciendo uso, cuando ello era posible, de elementos ya existentes. Las dos instituciones en torno a las que se vertebró la mayor parte de los trabajos promovidos por la Junta fueron el Centro de Estudios Históricos y el Instituto Nacional de Ciencias Físico-Naturales. El Centro de Estudios Históricos fue creado por R.D. de 18 
de marzo de 1910, con Ramón Menéndez Pidal como presidente y Tomás Navarro Tomás de secretario. Dos meses después, un R.D. de 27 de mayo firmado por el ministro de Instrucción Pública, conde de Romanones, puso en marcha al Instituto Nacional de Ciencias Físico-Naturales, con Ramón y Cajal de presidente y Cabrera de secretario.

Los establecimientos ya existentes que la Junta incoporó al Instituto Nacional de Ciencias fueron: Museo Nacional de Ciencias Naturales (dirigido por Ignacio Bolivar), Museo de Antropología (Manuel Antón y Ferrándiz), Jardín Botánico (Apolinar Gredilla), Estación Biológica de Santander, y el Laboratorio de Investigaciones Biológicas (Santiago Ramón y Cajal) que, en 1920, se convertiría en el Instituto Cajal. Los nuevos laboratorios creados por la Junta fueron: Instituto Nacional de Física y Química, erigido de nueva planta gracias a un generoso donativo de la Fundación Rockefeller; inaugurado en septiembre de 1931, sustituyo al antiguo Laboratorio de Investigaciones Físicas, ambos dirigidos por Blas Cabrera. Fueron también de nueva creación: Estación Alpina de Guadarrama (desde 1910-11); Laboratorio de Anatomía Microbiológica (1912, Luis Calandre); Laboratorio de Histología e Histopatología del Sistema Nervioso, dirigido primero por Achúcarro (1913) y luego por Río Hortega; Laboratorio y Seminario Matemático (1915); Laboratorio de Fisiología General (1916, Juan Negrín); Laboratorio de Química Fisiológica (1916, Antonio Madinaveitia); Laboratorio de Serología y Bacteriología (1920, Paulino Suárez), y Misión Biológica de Galicia (1921, Cruz Gallástegui).

La fisiología había tenido dos dignos representantes: Rafael Martínez Molina (1816-1888) dirigió, en Madrid, el Instituto Biológico, donde inició la asimilación de las tendencias químicas y experimentales; luego colaboraría con la Escuela Libre de Medicina de Sevilla primero y, después, con la Academia y Laboratorio de Ciencias Médicas de Barcelona. Por su parte, bajo la influencia de Claude Bernard -autor de la famosa Introducción al Estudio de la Medicina Experimental (1865) que sería traducida por Antonio Espina y Capo - se desarrolló en torno a las mismas fechas -1868- un movimiento fisiológico encabezado por Ezequiel Martín de Pedro. De todos modos, los avances en fisiología, patología y química no se vieron reflejados en la práctica médica; ello, principalmente, por la limitación del equipamiento disponible.

Por fin, la fisiología, con escasa tradición en España, recibió el impulso esperado, en Madrid, de la mano de Juan Negrín López (18921956), formado en Alemania y que sucedió en la Cátedra de la Universidad Central a José Gómez Ocaña (1860-1919). Gómez Ocaña fue el 


\section{La época de Santiago Ramón y Cajal}

pionero de la fisiología madrileña; escribió: Tratado de Fisiología de la Circulación, Cádiz 1894; Fisiología del Cerebro, Madrid 1894, y Fisiología Humana Teórica y Experimental, Madrid 1896, que fue un clásico entre los libros de texto. Negrín, que representó (1933) a España en la Organización Internacional del Trabajo y en la Unión Interparlamentaria Europea, que desempeñó la cartera de Hacienda (1936) en el Gobierno de Largo Caballero y que fue Presidente del Gobierno de la República (1937-1945), formó una escuela a la que pertenecieron José Domingo Hernández Guerra -el colaborador más habitual de Negrín-, José Sopeña Boncompte y José $\mathrm{M}^{\mathrm{a}}$ del Corral quienes representaron el primer núcelo de investigadores asociados al Laboratorio de Fisiología. Luego vendrían Severo Ochoa, Grande Covián, García Valdecasas, Rodríguez Delgado y Puche o Rafael Méndez.

En Barcelona, coetáneo de Gómez Ocaña fue Ramnón Turró i Darder (1854-1926), quién sucedió a Ferrán en la dirección del Laboratorio Municipal de Barcelona. Pero el impulsor de la escuela fisiológica catalana fue Augusto Pi y Suñer (1879-1965) - La Unidad Funcional. Ensayos de Fisiología Interorgánica (1918), Los Mecanismos de la Correlación Fisiolológica (1920)-. De la mano de la fisiología, en Cataluña, se desarrolló la bacteriología; figuras destacadas fueron Jaime Ferrán Clua (1852 1929) -director del Laboratorio Microbiológico Municipal de Barcelona, preparó vacunas anticolérica (1884), antitífica (1887) y antituberculosa o antialfa - y, sobre todo, Francisco Durán Reynalds (1899-1958), pionero en oncogénesis viral. Durán-Reynals nació en Barcelona, en 1899, graduándose en Medicina en 1925; pasó un año en el Instituto Pasteur, en París, para trasladarse al Instituto Rockefeller en el que permaneció has ta 1938 en que se desplazó a Yale donde trabajó hasta su muerte.

No debe olvidarse el papel motriz del Institut d'Estudis Catalans creado por la Diputación Provincial de Barcelona en 1907, y por iniciativa de su entonces Presidente, don Enric Part de la Riba, con la función primordial de promover la investigación científica y, de modo muy principal, la cultura catalana. El Institut, para mejor llevar a cabo su contenido, creó también una serie de servicios, seminarios y laboratorios de investigación dependientes de sus Secciones. Entre ellos, y haciendo referencia tan solo a los que dependían de la Sección de Ciencias, creada en 1911, merecen ser recordados por sus meritorias publicaciones el Institut de Fisiología, el Server Geológic i Geográfic y la Estació Aerológica de Catalunya. A partir de 1913 y con la finalidad de hacer posible la incorporación de más amplios núcleos reinvestigadores a sus empresas científicas el Institut creó una serie de entidades filiales como la Societat de 
Biología de Barcelona (1913), la Societat Catalana de Filosofía (1922), la Societat Catalana de Ciencias Fisiques, Quimiques y Matematiques (1931), la Societat Catalana de Geografia (1935) y otras tantas a partir de 1945. Por otra parte, la Institució Catalana d'Historia Natural, fundada en 1899, también se convirtió, en 1915, en filial del Institut. Un Real Decreto de 26 de noviembre de 1976 otorgaba reconocimiento oficial al Institut.

La genética se introdujo de la mano de dos centros: el Laboratorio de Bio logía - dirigido por Zulueta- en el seno del Museo Nacional de Ciencias Naturales, y un segundo de nueva creación, la Misión Biológica de Galicia dirigida por Gallástegui. Antonio de Zulueta y Escolano (1885-1971), perteneciente a la Generación de 1914 -la Generación de Ortega y García Morente en Filosofía, de Font Quer en Botánica, de Del Rio Hortega y Pi Suñer en Medicina-, formó parte del grupo de jóvenes que fundó en Barcelona la Institució Catalana d'Historia Natural (1899), fue socio de la Real Sociedad Española de Historia Natural desde 1905 y, al año siguiente, alumno dela Estación de Biología Marina de Santander. A los 18 años publicó sus dos primeros trabajos. Se licenció en Ciencias por la Universidad de Madrid en 1909 y, en 1910 por la de París. En 1911 es nombrado conservador de la sección de vertebrados del Museo Nacional de Ciencias Naturales a la vez que la JAE le encarga en el mismo centro un curso práctico de Biología que significa el origen del Laboratorio de Biología. En el cuarto de siglo (1911-1936) de vida de ese laboratorio - comenta Valderas- fueron discípulos suyos o colaboradores, entre otros: Nicolás Achúcarro, Manuel Alía, Emilio Anadón, Cándido Bolívar, Federico Bonet, Manuel Bordás, Florencio Bustinza, José Fernández Nonídez, Käte Pariser, Reichenow, Enrique Rioja Lo Bianco, Rur bio Sama y Pariser. Entre 1920 y 1922 tradujo obras de Darwin, Morgan, Scott y Newman relacionadas con la genétića y la evolución. En 1925 publicó un interesante trabajo cuya conclusión era la explicación de un fenotipo ad mitiendo la trasmisión de genes por el cromosoma Y; que si bien no era nue va, si era la primera vez que a la evidencia genética se unía la comprobación citológica. En 1930 Zulueta, invitado por Thomas Hunt Morgan y becado por la Fundación Del Amo, trabajó en el Instituto Tecnológico de California en Pasadena. En la Cátedra Conde de Cartagena de la Real Academia de Ciencias impartió, entre 1932 y 1936, una serie de cursos de genética. Por su parte, un intento de colaboración entre el Museo de Ciencias Naturales y la Fundación Rockefeller para dotar un nuevo Laboratorio de Biología, se vio truncada por la Guerra Civil. José Fernández Nonídez, discípulo aventajado de Zulueta, fue catedrático de zoología en la Universidad de Murcia y recibió, en 1917, una beca de la JAE para trabajar en el laboratorio de Morgan 


\section{La época de Santiago Ramón y Cajal}

en la Universidad de Columbia. De vuelta a España, en 1920, dictó un ciclo de conferencias en el Laboratorio de Biología de Zulueta; pero al año siguiente retornó a EE.UU, ubicándose, primero en la Universidad de Cornell y, luego, en la de Georgia, abandonando la genética y dedicándose a la anatomía e histología.

La Misión Biológica de Galicia abrió sus puertas en marzo de 1921 y gracias a las gestiones de Juan López Suárez -estudió genética en EE.UU. en 1916 como pensionado por la JAE-, a través de la Sociedad Económica de Amigos del País ante la JAE, con el fin de crear una estación «con el objeto de realizar investigaciones y trabajos científicos relacionados con los problemas agrícolas e industriales que en la región Gallega existen». Fue nombrado director Cruz Gallástegui Unamuno, quién a su regreso a Es paña, tras estudiar en Francia y Alemania entre 1910-4, se había ocupado de la explotación de los hermanos López Suárez en Lugo. A instancias de Juan López Suárez, Gallástegui de desplazó a EE.UU. donde estudió (1917-21) genética en las Universidades de Harvard y de Cornell y en la Estación de Agricultura Experimental de Connecticut. Durante su etapa al frente de la Estación Gallega se ocupó, preferentemente, del «problema del castaño» y de la mejora del maíz y de la raza porcina «Large White». Fueron becarios de la Estación Vicente Boceta y Miguel Odriozola.

Por su parte, los estudios botánicos en España experimentaron -señalan González Bueno y Gallardo- un espectacular auge a comienzos de la segunda década del siglo XX, prolongado hasta la Guerra Civil. Las razones de este desarrollo deben buscarse -continúan los autores citados- en la infatigable labor realizada por Pío Font Quer desde el Museo de Ciencias Naturales de Barcelona, que llevará a la creación de un Instituto autónomo dedicado, con exclusividad, a los estudios botánicos y financiado por la Junta de Ciencias Naturales de Barcelona; y en la reorganización de la investigación botánica realizada bajo los auspicios de la JAE desde el Instituto de Ciencias Físico-Naturales. Desde la creación de la Junta y hasta 1921, los estudios botánicos patrocinados por ella fue ron realizados en los locales del Museo de Ciencias; sólo después de ese año se trasladaron al Jardín Botánico de Madrid.

Entre los intentos reformistas tras la creación (27 de mayo de 1910) del Instituto Nacional de Ciencias Físico-Naturales figuró la renovación de la estructura y funcionamiento del real Jardín de Madrid. El nombramiento (R.D. de julio de 1910) de nuevos jefes de sección -Blas Lázaro Ibiza y José Madrid Moreno- chocó frontalmente con el director del Centro, Federico Gredilla. A pesar de la comisión nombrada por Cajal (noviembre 1913) y que resultó en la inspección realizada por José Gómez 
Ocaña, la situación del Real Jardín quedó bloqueada hasta 1921, fecha de la muerte del director Eduardo Reyes Prosper que había sucedido a Gre dilla. Se nombró, entonces, a Ignacio Bolivar director del Real Jardín Botánico; con ello, la situación dio un vuelco. Con los antecedentes de los Cursos dictados por el francés Leclerc du Sablon y el norteamericano Lewis Knudson, celebrados en el Museo de Ciencias entre los años 1917 y 1921 y que supusieron el embrión del Laboratorio de Fisiología Vegetal, cuta dirección se encomendó a Antonio García Varela, ya de la mano de Bolivar en el Jardín Botánico. Luis Crespi, José Rodríguez Sardina, Enri que García Subero, Miguel Ángel Junquera Muné o Manuel Castañeda Agulló., fueron investigadores en el Jardín Botánico. Pero de todos los que pasaron por el Laboratorio de Fisiología Vegetal, fue Florencio Bustinza Lachiondo (1902-1981) el que desarrolló una labor más amplia en él. Bustinza fue catedrático de Agxicultura en el Instituto de Oviedo, disfrutando a partir de 1927 de una pensión de la JAE para estudiar en el Instituto Botánico de la Universidad de Ginebra. De regreso a España se doctoró en Farmacia y en Ciencias, trasladándose a Madrid en 1930, donde ejerció como Catedrático de Agricultura en el Instituto Cardenal Cisneros; se vinculó al Laboratorio y sucedería en la Cátedra a García Varela.

Con todo, en 1932 la Junta perdió a su secretario; don José Castillejo fue nombrado, en septiembre de 1932, director administrativo de la Fundación Nacional para Investigaciones Científicas y Ensayos de reformas). Le sustituyeron Prieto Bances y Tomás Navarro Tomás. Por su parte, la dirección de la JAE, tras la muerte de Cajal, pasó a las manos de Ignacio Bolivar. En diciembre de 1936 se nombra una Comisión provincial en Valencia para continuar la labor de la Junta. A comienzos de 1938 se creaba, en la zona «nacional», el Ministerio de Educación Nacional con Pedro Sainz Rodríguez como ministro, quién suscribió un decreto de fecha 19 de mayo por el que quedaba disuelta la JAE, repartiéndose sus servicios entre las Universidades y el Instituto de España, anunciándose para «fecha próxima y ocasión también de alto significado nacional la organización de otro grupo de Instituciones concernientes al estudio de las Ciencias de la naturaleza y matemática». En noviembre de 1939 se crearía el Consejo Superior de Investigaciones Científicas.

\section{f. Asociación Española para el Progreso de las Ciencias}

La constitución de la Asociación Española para el Progreso de las Ciencias (AEPC) fue uno de los resultados -señala García Sierra-de un 


\section{La época de Santiago Ramón y Cajal}

proceso más amplio (político, filosófico, científico) que convencionalmente se inicia a partir de la muerte de Fernando VII (1833), cuando ya no cabía dar marcha atrás al proceso de modernización de España. La AEPC fue una institución heredera de las tendencias progresistas y liberales íntimamente vinculada en su origen a los componentes más avanzados de las distintas Instituciones culturales, entre cuyos miembros se encontraban figuras destacadas de la vida política y científica del momento y en los que habían calado las ideas positivistas de "Orden-Progreso-Ciencia» propuestas por Comte en su "Curso de filosofía positiva"

En la Memoria leída por el Secretario general de la AEPC -don Ricardo García Mercet- en la sesión inaugural (22 de octubre de 1908) del I Congreso de la Asociación, se explicitan los antecedentes:

"... El Congreso cuyas tareas hoy se inauguran, puede decirse que carece de antecedentes en nuestro pais. Asambleas nacionales ó internacionales se han celebrado muchas en España, á partir de la época en que este modo de comunicación entre los hombres cultos empezó a ponerse en boga más allá de nuestras fronteras. Pero todas las que hasta la fecha se reunieron aquí tenían un carácter de clase muy restringido y acentuado: eran de médicos, de ingenieros, de arquitectos, de farmacéuticos, de agricultores solamente. Un Congreso como el actual, al que concurren abogados, filósofos, naturalistas, matemáticos, astrónomos, químicos, las clases médicas en general, ingenieros de todas procedencias y militares de todas las armas y cuerpos del ejército, no se había visto nunca en el territorio de la Península. Por esto la expectación que ha despertado entre la intelectualidad española es enorme. Por esto que de todas partes nos vengan adhesiones y nos envien ofrecimientos. Por esto el favor que el Gobierno, las Academias, las Sociedades de cultura, los Centros de enseñanza y otras entidades y Corporaciones nos han otorgado. Por esto, en fin, la curiosidad y las simpatías generales con que se acoge nuestra presentación. Y es que toda España ve en nuestra empresa algo más que una mera reunión de eruditos y de investigadores; algo más que un campo de exhibiciones personales y de exposición de estudios. Ve en esta obre de cultura una obra á la vez de mutua compenetración; ve que á favor de ella pueden fortalecerse y afianzarse los lazos que unen á nuestras clases intelectuales; ... sabed que al Congreso cuya apertura celebramos, junto á lo más granado y escogido de la intelectualidad española, al lado de los sabios de fama y nombradia ya mundiales, vendrán una porción de jóvenes que sólo son conocidos en el laboratorio, en la escuela ó el gabi- 
nete de su trabajo, pero á los que importa mucho estimulen y vayan creando una personalidad los hombres ya hechos y conocidos; ... Pero, ¿cómo hemos llegado á reunirla?. .. En el mes de Diciembre último, la Sección que aquí, en Zaragoza, tiene establecida la Real Sociedad de Historia Natural, propuso á la Junta directiva de Madrid organizar un Congreso Nacional de naturalistas, que se celebraría en esta histórica población durante las fiestas del Centenario de los Sitios. El pensamiento fue acogido con entusiasmo, estudiado con detenimiento y discutido con amplitud de miras, conviniéndose, después de maduro examen, proponer á los naturalistas aragoneses la organización de una asamblea más extensa, á la que pudieran ser convocadas todas las profesiones cientificas y llamados cuantos se dedican en España á los estudios de investigación.

Modificado ó transformado de esta manera el proyecto que se concibió en Zaragoza, y con propósito decidido de llevarlo adelante, pensando que habia que buscarle un alto patrocinador, si al fin habia de prosperar. El Presidente, á la sazón, de la Sociedad Española de Historia Natural, D. Luis Simarro, visitó con este objeto al Excmo. Sr. D. Segismundo Moret, Prendesgast [Presidente del Ateneo de Madrid] enterándole de nuestros deseos y aspiraciones; el señor Moret aún amplió y mejoró los planes que se le exponían, y de la visita aquélla salió el proyecto de fundar en nuestro país la Asociación Española para el progreso de las Ciencias, con un programa semejante al de las Sociedades que, bajo un nombre análogo, funcionan desde hace muchos años en Inglaterra, Suiza, Francia, Alemania, los Estados Unidos y otros paises tan prósperos y cultos como los enunciados. A los pocos días, el 2 de Enero del año actual, se verificaba en el salón de actos del Ateno Científico, Artístico y Literario Madrileño una reunión magna, bajo la presidencia del Sr. Moret, á la que asistían representantes de las Academias, de los Centros docentes, de las Sociedades Científicas, de los Laboratorios y de la Prensa política y noticiera, y allí quedó acordado el establecimiento de nuestra Asociación.

Para formar los Estatutos á que el práctica habría de ajustarse, de entre los concurrentes, el Sr. Moret, designó una Comisión compuesta por el ex Ministro de Marina D. Victor María Concas, el General de Estado Mayor D. Leopoldo Cano y los Catedráticos de la Universidad Sres. D. Luis Simarro y D. José Rodríguez Carracido.

La actividad desplegada por estos ilustres comisionados fue tanta que, el 23 de Febrero, pudo verificarse en el mismo local que la primera una nueva reunión, en la que quedó aprobado el reglamento de 


\section{La época de Santiago Ramón y Cajal}

la naciente Sociedad y acordada la celebración de su primer Congreso en Zaragoza, dentro de las fiestas señaladas para las fiestas del Centenario de los Sitios. El Comité ejecutivo de la Asociación, que todos conocéis, fue nombrado también aquel mismo día; á los pocos se eligieron y designaron las Secciones que han venido funcionando en Madrid para organizar el Congreso, y no mucho después se puso mano en la composición del Comité local de Zaragoza ...

Todo esto es altamente halagüeño y consolador. Las energías, las muestras de vitalidad de que los españoles van dando señales y de que es bravo pregón esta Asamblea, permiten que de una vez desechemos los negros pesimismos que abatían nuestro espíritu desde los días aciagos, inolvidables, de 1898. España no muere. Resurge, animosa, confortada y resuelta, después del desastre. iSursum corda!. He dichan.

Los Estatutos de la Asociación junto con el Reglamento y Programa del Congreso de Zaragoza se publicaron en un folleto editado en Madrid (Imprenta Alemana) en 1908:

"Artículo $1^{\circ}$. La Asociación tiene por objeto el fomento de la cultura nacional, en sus manifestaciones científicas principalmente. Para conseguirlo organizará Congresos, conferencias y concursos; procurará la fundación de instituciones de enseñanza; favorecerá la comunicación intelectual entre el país y las clases asociadas, y auxiliará, en la medida que sus recursos lo permitan, los trabajos y estudios de investigación. ...

Artículo 22. La Asociación celebrará periódicamente Congresos cientí ficos nacionales.

Artículo 23. Cada Congreso estará dividido en las secciones siguientes: de Ciencias Matemáticas; de Ciencias Físico-Químicas; de Ciencias Naturales; de Ciencias Sociales; de Ciencias Filosóficas; de Ciencias Médicas, y de Aplicaciones. ...

Artículo 29. Como la Asociación, además de fomentar el estímulo entre las clases intelectuales, desea que alcance su influencia á la educación popular, organizará durante las Asambleas y en los intervalos de éstas conferencias públicas sobre cuestiones de interés general.

... Los precedentes Estatutos fueron aprobados con carácter de regla provisional en reunión celebrada el 23 de febrero de 1908, en el Ateneo de Madrid, y su ratificación se verificará en la sesión de clausura del Congreso de Zaragoza, en la que se dará por definitivamente constituida la Asociación." 
Fue elegido Presidente del Comité ejecutivo de la Asociación el Excmo. Sr. D. Segismundo Moret y Prendergast, Catedrático de la Universidad de Madrid y Presidente del Ateneo Científico, Literario y Artístico. Fueron los Vocales: Eduardo Mier (Ingeniero geógrafo, de la Real Acade mia de Ciencias, Presidente de la Sociedad Española de Física y Química), José R Carracido (de las Reales Academias de la Lengua, Ciencias y Medicina, Catedrático de la Facultad de Farmacia de la Universidad de Madrid), Luis Simarro (Catedrático de la Facultad de Ciencias de Madrid, Presidente de la Real Sociedad Española de Historia Natural), Le opoldo Cano (Director de la Escuela Superior de Guerra), Gumersindo de Azcárate (de la Real Academia de Ciencias Morales y Políticas, Catedrático dela Facultad de Derecho de Madrid, Presidente del Instituto de Reformas Sociales), Victor María Concas (ex Ministro de Marina), Ángel Pulido (de la Real Academia de Medicina, Presidente del Colegio de Médicos de Madrid), Ignacio Bolívar (Decano de la Facultad de Ciencias de Madrid, Director del Museo de Ciencias Naturales), Perfecto María Clemencín (Director de la Escuela de Ingenieros de Minas), Enrique Fort (arquitecto), Manuel Zabala (Director del Instituto de San Isidro de Madrid), José Marvá (General de Ingenieros), José Gómez Ocaña (de la Real Academia de Medicina, Catedrático de la Universidad de Madrid), Gabriel Maura Gamazo (Doctor en derecho), Vizconde de Eza (ex Director de Agricultura, Industria y Comercio) y Ricardo Codorniú (Ingeniero de Montes). Fueron los secretarios Ricardo García Mercet (Farmacéutico mayor de Sanidad Militar y Secretario de la Real Sociedad Española de Historia Natural) y Vicente Vera (Profesor del Instituto de San Isidro, doctor en ciencias físico-químicas).

Por su parte las presidencias de las Secciones fueron ocupadas por: $1^{a}$ Sección -Ciencias Matemáticas, José Echegaray (de las Reales Academias Española y de Ciencias, Catedrático de la Universidad de Madrid); $2^{a}$ Sección-Ciencias Físico-Químicas, Francisco de Paula Rojas (de la Real Academia de Ciencias, catedrático jubilado de Física matemática); $3^{a}$ Sección -Ciencas Naturales, Santiago Ramón y Cajal (de las Reales Academias Española, de Ciencias y de Medicina, Catedrático de la Universidad de Madrid y Director del Laboratorio de Investigaciones Biológicas de la JAE); $4^{\text {a }}$ Sección- Ciencias Sociales, Gumersindo de Azcárate; $5^{a}$ Sección-Ciencias Filosóficas, Marcelino Menéndez Pelayo (de las Re ales Academias Española, de la Historia, de Bellas Artes y de Ciencias Morales y Políticas, Director de la Biblioteca Nacional); 6 a Sección- Ciencias Médicas, Julián Calleja (de las Reales Academias de Ciencias y de Medicina, Decano de la facultad de Medicina de Madrid y Director del 


\section{La época de Santiago Ramón y Cajal}

Instituto de epilépticos, fundación del Marqués de Vallejo), y $7^{\mathrm{a}}$ SecciónAplicaciones, Eduardo Saavedra (de las Reales Academias Española, de Ciencias y de la Historia).

La primera etapa (1908-1927) de la AEPC -que Elena Rozón denomina «etapa dorada de la Asociación- estuvo dominada por el criterio de los miembros pertenecientes a la Real Academia de Ciencias, impregnados por el ideario liberal progresista y el positivismo. La presidencia durante este periodo paso de Segismundo Moret (1908-13) a Echegaray (19136), luego a Eduardo Dato (1916-21) y, finalmente, a José Rodríguez Carracido (1921-8). Sin embargo, pronto se detectaron síntomas de una contestación "reaccionaria». La influencia de la Academia de Ciencias fue desplazada, paulatinamente, por la de la Academia de Ciencias Morales y Políticas; ello a través de las Secciones de Ciencias Sociales y de Ciencias Históricas, Filosóficas y Filológicas. Este desplazamiento, progresivo, incluso fue favorecido por algunos miembros de la de Ciencias; por ejemplo, Obdulio Fernández y Rodríguez, Catedrático de la Facultad de Farmacia de Madrid, en su discurso de toma de posesión de la Medalla $\mathrm{n}^{\circ} 31$ de la Real Academia de Ciencias, en junio de 1918, manifestó que «a la Academia de Ciencias Morales y Políticas corresponde por derecho la organización económica de las industrias futuras, puesta de acuerdo con la de Exactas, Físicas y Naturales».

Para García Sierra, 1927 marca el inicio de una segunda etapa (19271940) definida por un cambio de rumbo; ello ocurrió, específicamente, con el discurso inaugural del XI Congreso de la AEPC en Cádiz. Luis Marichalar y Monreal, Vizconde de Eza, que sucedería a Carracido en la Presidencia e la Asociación (1928-1945), autor del discurso mencionado, indicó un giro completo respecto a lo que, en adelante, se entenderá como verdadero cultivo y desarrollo de la ciencia en España. Los intereses de la AEPC ya no serán los mismos que los dela etapa anterior. Ahora ya no tendrá tanta importancia exigir el desarrollo y cultivo de las ciencias positivas, ni la reforma de los planes de estudio para favorecer los estudios experimentales que permitan at canzar el desarrollo industrial propio de una nación moderna -sin perjuicio de que no se niegue la importancia de esto-, sino que bastará con favorecer el desarrollo de aquellos estudios encaminados a poner de manifiesto lo propio y característico del alma nacional, del espíritu del pueblo español, cuyos rasgos aparecerán expresados en las obras filosóficas, teológicas y morales. Sin embargo, en esta segunda etapa caben destacar dos hechos: el compromiso de la Asociación a propuesta de su Presidente para continuar el plan de una Historia dela Filosofía española, y la publicación de los Anales de la Asociación Española para el Progreso de LAS CIENCIAS. 
Tras un intervalo de veinticuatro años se reanuda con el presente volumen -dice la Advertencia preliminar del primer volumen- la publicación de la Historia de la Filosofía Española, comenzada en 1908 por el Dr. Adolfo Bonilla y Sanmartín -siguiendo las directrices de su maestro D. Marcelino Menéndez Pelayo-y detenida en el segundo tomo, aparecido en 1911, a causa de la temprana muerte del ilustre profesor. La AEPC anunció, en 1929, un Concurso en homenaje y estímulo de la ciencia española, para la adjudicación de cinco premios - de los que sólo se adjudicaron tres- fundados y costeados por su Presidente, Excmo. Sr. Vizconde de Eza, a otros tantos estudios que continuasen la Historia de la Filosofía Española, comenzada por D. Adolfo Bonilla y Sanmartín. El importe de cada premio era de veinte mil pesetas, más cinco mil para la publicación. Los estudios premiados fueron: «Premio Moret»-resuelto en 1935- a la memoria Filosofía Cristiana de los siglos XIII al XV, presentado por Tomás Carreas y Artau (Catedrático de la Universidad de Barcelona) y por Joaquín Carreras y Artau (Catedrático del Instituto de $2^{\mathrm{a}}$ enseñanza «Balmes» de Barcelona); la obra se publicó en dos tomos, el Tomo I en 1939 y el Tomo II en 1943. "Premio Echegaray» -fallado en 1936- a la memoria Filosofía en la Época del renacimiento: siglo XVI, presentado por el Doctor Marcial Solana; la obra se publicó tres tomos en el año 1941. "Premio Bonilla Sanmartín» a la memoria Historia de la Filosofía Hispano-Musulmana, presentada por Miguel Cruz Hernández, catedrático de la Universidad de Salamanca; la obra se publicó en dos tomos en el año 1957.

En 1934 (coincidiendo con el cambio de domicilio de la AEPC que pasaría, hasta su disolución en 1979, a compartir los locales de la Real Academia de Ciencias Exactas, Físicas y Naturales) se inicia la publicación de Las Ciencias. José María Torroja, Secretario General de la AEPC - había sucedido en el cargo a Ricardo García Mercet, en 1933- en el discurso inaugural del XV Congreso de la Asociación, celebrado en Santander en 1938, comentaba:

"... Hace cinco años, al tomar posesión del cargo de Secretario General de la AEPC ...presenté a la Junta Directiva la proposición de editar una Revista que reuniera y completase la labor de sus Congresos bienales. Concebía yo esta publicación como elevada difusora de los progresos de las Ciencias y de las Letras. No una Revista que diera a conocer novedades de la investigación a sus propios cultivadores, sino las líneas generales de sus adelantos y precisamente a aquellos que en las mismas no participaban. Una publicación, en suma, que fuera lei- 


\section{La época de Santiago Ramón y Cajal}

da con interés por los hombre cultos en todas las secciones, más que en la propia, porque de los que ésta dijere, cada uno estaba ya enterado. ... Apoyada decididamente la idea por el Presidente y la Junta Directiva de la Asociación, y encargado yo de su realización como Redactor Jefe, la revista trimestral Las Ciencias apareció en $1^{\circ}$ de enero de 1934».

Luis Marichalar, Vizconde de Eza, Presidente de la AEPC escribía en la Presentación y Saludo del número uno del año I de la Revista Las Ciencias:

"Realizamos con la publicación de la revista LAS CIENCLAS una de las ilusiones más caras que abrigábamos desde nuestra elevación -en 19-, tan honrosa como inmerecida, a la Presidencia de la AEPC. La labor científica llevada a cabo por esta entidad durante los veinticinco años que cuenta ya de existencia se demuestra con la verdadera biblioteca que constituyen los tomos de los catorce Congresos celebrados, sin interrupción cada bienio, con un interés y entusiasmo siempre crecientes. ... la Junta Directiva de la Asociación ..., ha creído llegado el momento de imprimir un nuevo impulso al cometido que nos está asignado. ... Queremos, por tanto, vivir en comunicación directa y asidua con nuestros socios y con el público estudioso en general. La Revista que hoy nace y que desearíamos que llegase a ser pronto mensual, se compondrá de tanteas secciones como son las que hay en el seno de nuestra Asociación. ... Concebimos la Revista como una síntesis del estado de la Ciencia en el periodo que cada número abarque ... El deseo es bueno, la intención sana, el propósito patriótico, y el fin puramente de divulgación científica...".

En el número 4, del año XXV, correspondiente a 1960 y siendo Manuel Lora Tamayo el Prtesidente de la AEPC, Las Ciencias concluía:

"... parece oportuno modificar hoy la organización de Las Ciencias. A partir de nuestro próximo número modificaremos su formato y su contenido...". Y en el número 1, del año $s X V I$, correspondiente a 1961, "Una nueva época»: ".. Desearíamos que, con el transcurso del tiempo y el desarrollo de adecuadas colaboraciones, la revista saliera del círculo, más o menos amplio, pero siempre limitado, de las suscripciones, a la libre solicitación de la calle, con el deseo de que esta pretendida difusión alcanzara a capas de población lo más am- 
plias posible, contribuyendo así a una elevación del nivel científico en el ciudadano medio».

La historia de la AEPC termina, prácticamente, en 1979 -año en que se celebró el XXXIII y último Congreso- y aunque Las Ciencias siguió apareciendo (con su nuevo formato desde 1961) hasta 1981.

\section{El Contexto Médico}

g. Hacia la modernización de la medicina española

«Fernandinos» fueron los profesionales que, nacidos en su mayoría en los últimos años del siglo XVIII, iniciaron su actividad con posterioridad a la guerra de la Independencia y se adentraron en los años del gobierno de Isabel II. Escribe López Piñeiro que las disciplinas fundamentales, como la anatomía y la fisiología, habían alcanzado en la España de los últimos años ilustrados uno de sus momentos de esplendor. Sin embargo, el denominado por ese autor «periodo de catástrofe» (1800-1832) dio al traste con las expectativas creadas. Mateo Seoane Sobral (1791-1870), doctorado en Medicina por la Universidad de Valladolid en 1813, escribía en 1819: ... a cualquier parte que se vuelva la vista, ino se encuentra rutina para estudiar, rutina para hablar, rutina para pensar, rutina para curar y hasta rutina para visitar? .. La moda manda ahora rutinear. Eso se decía en la época de Laenec (1781-1826) en Francia, fundador del mé todo anatomoclínico e inventor de la auscultación; de Bright (1789-1858) en Inglaterra, que demostró el valor semiológico de los datos del laboratorio, y de Liebig (1803-1873) en Alemania, creador del término «metabolismo». Seoane, exiliado en Londres por su condición de diputado liberal desde 1823 hasta 1834, a su regreso a España publicó una Memoria sobre el estado actual de las ciencias en Epaña (Madrid, 1842) que fue -en palabras de Francisco Guerra- punto de partida para la reorganización de la enseñanza y la práctica de la medicina en España.

Sin embargo, hubo figuras interesantes. Entre ellos, el anatomista Lorenzo Boscasa Igual (1786-1857), que publicó, en 1844, un Compendio de Anatomía General y Descriptiva; los fisiólogos Juan Mosácula Cabrera (1794-1831) -autor de unos Elementos de Fisiología- y, sobre todo, Joaquín Hysern Molleras (1804-1883), que realizó una labor experimental original que fue criticada -le acusaron de dar mucha importancia a los experimentos- y careció de continuación. La transición al pensamiento 
anatomoclínico la cumplieron Antonio Hernández Morejón (1773-1856) en Valencia y en Madrid, y Francisco Juanich (1798-1868) en Barcelona; con todo, el foco principal de la nueva mentalidad estuvo en Cádiz, siendo sus representantes Pedro María González (1763-1837) y Francisco Laso de la Vega y Orcajada (1785-1836), líder de un grupo de clínicos integrado por Manuel J. de Porto y por José de Gardoqui. Las primeras ideas modernas sobre patología médica aparecen en Manuel José de Porto y Zepillo (17921860), quién escribió el primer manual español de anatomía patológica (Tratado de Anatomía Patológica, Cádiz, 1846) basado en textos franceses aunque con observaciones personales pero sin estudio microscópico. José de Gardoqui y Paino (1807-1857), gaditano como de Porto, estudió en París y se doctoró en Madrid, en 1844, tras haber publicado un Tratado de las enfermedades del aparato respiratorio (Cádiz, 1940, en el que aparecen las primeras muestras del método diagnóstico anatomoclínico, la auscultación, la percusión, el análisis de la respiración y el carácter de los esputos.

A pesar del bajo nivel del saber médico hubo, entre 1800 y 1848 , técnicos de cirugía de notable valor. La cirugía "fernandina» estuvo representada por Diego de Argumosa Obregón (1792-1865), considerado el Restaurador de la cirugía española y el representante más genuino y genial de la cirugía española de su tiempo; Argumosa introdujo la anestesia en España, técnica que había sido presentada en EE.UU. en público y por primera vez con éxito, en 1846. Cirujanos fernandinos fueron, también, Antonio San Germán (1755-1833), autor de un libro de texto utilizado durante muchos años; José Rives y Mayor (1758-1842), cultivador de los estudios anatómico-quirúrgicos y defensor de la anatomía patológica; Melchor Sánchez de Toca (1806-1880), médico de Isabel II, y Tomás Corral Oña (1807-1882), que asistiría al nacimiento de Alfonso XII; todos ellos, seguidores del movimiento anatomopatológico, fueron profesores de la Facultad de Medicina de Madrid. Por su parte, la higiene y la política sanitaria contaron con Pedro Monlau Roca (1808-1871) y con Francisco Méndez Álvaro (1805-1883), siendo de 1833 una circular en la que se reconocía el «lastimoso estado a que por la calamidad de los tiempos han llegado la mayor parte de los Hospicios, Hospitales y casas de Expósitos del reino». Méndez Álvaro fue discípulo de Seoane y, a partir de 1947, por su posición en el Consejo de Sanidad responsable de la gran reforma hospitalaria e higiénica en España. Su influencia fue aún mayor sobre la práctica de la medicina por haber fundado El Siglo Médico (1854), órgano de la Real Academia Nacional de Medicina.

Médicos «isabelinos» fueron aquellos que encauzaron la medicina hacia el nuevo siglo; en su haber contaron la introducción de la «medicina 
de laboratorio», de la que la anatomía patológica sería su más temprana manifestación y la que antes consolidaría. Entre ellos, el anatómico Carlos Silóniz Ortiz (1815-1898), que recopiló su labor docente en una serie de volúmenes con el título general de Cursos y publicó la monografía $\mathrm{Del}$ Microscopio en su Aplicación al Diagnóstico, Juan Fourquet Muñoz (1807-1865) y el anatómico y cirujano Pedro González Velasco (18151882), que fundó la revista El Anfiteatro Anatómico Español. Aureliano Maestre de San Juan Muñoz (1828-1890) ocupó la primera cátedra de histología dotada en España, fundó la Sociedad Española de Histología (1874) y colaboró en los textos Tratado de Anatomía General y Tratado de Histología Normal y Patológica. A la generación isabelina pertenecieron los médicos que protagonizaron una importante polémica doctrinal: positivismo frente a un añejo ideario hipocrático. Médicos hipocráticos fueron Tomás Santero Moreno (1817-1888), Matías Nieto Serrano (18131903) y, sobre todo, José de Letamendi Manjarrés (1828-1897), controvertida figura. Letamendi, catedrático de anatomía en Barcelona, su ciudad natal, y luego de patología general de Madrid desde 1878, fue el más significado crítico del positivismo; su concepción filosófica de la patología la abordó en su Tribiblion Médico, del que solo concluyó las dos primeras partes. La obra de Letamendi pretendió ofrecer una patología perenne, escrita al margen del imperante saber científico de la época.

Los positivistas estuvieron representados por Pedro Mata y por el más efectivo de los renovadores, el citado Ezequiel Martín de Pedro (1837-1875) quién renunció a una cátedra de Patología y clínica médica de Santiago de Compostela (1866) por una plaza de médico del Hospital General de Madrid, donde introdujo las ideas fisiopatológicas y bacteriológicas contemporáneas, los métodos anatomopatológicos microscópicos, la termometría clínica, pruebas auxiliares de laboratorio y otros métodos diagnósticos modernos. La adopción de los métodos diagnósticos y las doctrinas de la medicina positivista no partió de los profesores de clínica médica en la Facultad de medicina de Madrid, sino de los médicos del Hospital General, donde se hacía la clínica médica práctica. En Valencia y en Valladolid participó de ideas similares Amalio Gimeno Cabañas (1850-1936); publicó un popular Tratado Elemental de Terapéutica (Valencia, 1880), siendo profesor de Higiene y patología general en Madrid desde $1890 \mathrm{y}$, como senador y ministro en varias carteras, tuvo gran influencia en el progreso de la sanidad pública por su creencia de las ideas bacteriológicas sobre la transmisión de las enfermedades. Su aceptación de la fisiopatología aparece en su texto didáctico Tratado de Patologia General (Valladolid, 1886). En Barcelona fue decisiva laobra de 


\section{La época de Santiago Ramón y Cajal}

Bartolomé Robert Yarzabal (1842-1902), nacido en México pero afincado en Cataluña desde muy joven; alcalde de Barcelona, tradujo la Patología Celular de R. Virchow (1868) y publicó Enfermedades del Aparato Digestivo (Madrid, 1899).

La renovación médica iniciada incluyó una tímida emergencia de las especialidades médicas. La dermatología de la mano de Eusebio Castelo Sierra (1825-1892) y de José Olavide Landazábal (1836-1901) -impulsor del Hospital de San Juan de Dios de Madrid y autor de una Dermatología General y Clínica-, y la pediatría con Mariano Benavente (1818-1885). Con el antecedente, entre otros, de la Patología Psicológica de Juan Bautista Peset y Vidal, la psiquiatría se desarrolló en dos grupos. En Cataluña destacaron Emilio Pi i Molist (1824-1892), Juan Giné i Partagás (1836-1903) -cuya obra Tratado Teórico-Práctico de Frenopatología sirvió para institucionalizar la psiquiatría en España-y Arturo Galcerán -que fundó la Sociedad de Psiquiatría y Neurología de Barcelona-, todos ellos ocupados en la reforma de los nosocomios. El grupo madrileño se constituyó alrededor de Pedro Mata Fontanet (1811-1877), autor de un Tratado de la Razón Humana (1878) y creador en España de la medicina legal y del cuerpo de mé dicos forenses; a Mata le seguiría José María Esquerdo Zaragoza (18421912), que se distinguió por la creación de centros asistenciales.

La cirugía española de este periodo se vio afectada -comenta Riera-por la tardía aceptación del método antiséptico; en cambio, la anestesia por inhalación se aceptó inmediatamente después de su descubrimiento. Fue lenta, por otra parte, la adopción en la cirugía electiva de los métodos anatomoclínicos de exploración, el recurso a las pruebas diagnósticas de laboratorio y a los exámenes histopatológicos, así como la ejecución de las grandes intervenciones cavitarias según reglas asépticas regladas. Entre los cirujanos de comienzos del Positivismo destacó el malagueño Antonio Mendoza Rueda (1811-1872), quién hizo las campañas Carlistas como cirujano militar, alcanzando, en 1845, la cátedra de Anatomía quirúrgica en Barcelona; publicó Estudios clínicos de Cirugía (Barcelona, 1852). El sevillano Ramón Hernández Poggio (1823-1907) ingresó en la Sanidad Militar en 1848 y sirvió como cirujano en las guerras de África y de Cuba cuya experiencia vertió en su Tratamiento de las heridas por arma de fuego (Madrid, 1872). Las nuevas ideas quirúrgicas comenzaron a aparecer con Juan Creus Mansó (1826-1897), de Guadalajara; fue ayudante de D. de Argumosa, trasladándose luego a Granada y, posteriormente, a Madrid donde llegó a ser Rector de su Universidad en 1884; estudió la anestesia local y fue el introductor del termocauterio en la hemostasia y los métodos antisépticos en cirugía. Publicó numerosas obras; entre otras: Tratado ele- 
mental de Anatomía (Granada, 1861) y Ensayo teórico y práctico sobre las resecciones subperiósticas (Granada, 1862).

Federico Rubio y Galli (1827-1902), diputado a Cortes y Senador del Reino, fue el máximo exponente de la cirugía española de este periodo: el de los médicos isabelinos; personalidades plenamente abiertas a las más renovadoras corrientes doctrinales de la medicina europea que buscaron modernizar la formación médica al margen, casi siempre, del ámbito uni versitario, a la vez que se comprometieron en una sociedad políticamente sensibilizada. Licenciado en Medicina, en Cádiz en 1850 publicó antes de su graduación un Manual de Clínica Quirúrgica (Cádiz, 1949). Este pionero de la cirugía en España -Rubio fue coetáneo de Billroth (1829-1894), el cirujano más innovador de Europa- se caracterizó por practicar en cadáver todas las operaciones quirúrgicas que, en su tiempo, eran corrientes; ello le permitió introducir en nuestro país las técnicas quirúrgi cas más actuales y, también, practicar algunas innovadoras; además, tuvo un decidido interés por las bases científicas de la cirugía, la anestesia, la hemostasia y la antisepsia. Por sus ideas liberales tuvo que emigrar a Londres (1860); con la proclamación de la Primera República Española re gresó a Sevilla, donde creó la Escuela Libre de Medicina y Cirugía; fue ele gido diputado, luego senador y embajador en Gran Bretaña. De regreso a Madrid fundó, en 1880, el Instituto de Terapéutica Operatoria en el Hospital de la princesa que, en 1896 tuvo edificio propio como Instituto $\mathrm{Ru}$ bio, habiendo fundado un año antes una Escuela de Enfermeras. Se ocupó, también, de cuestiones sociales (Sociopatología, Madrid 1890).

$\mathrm{Al}$ igual que la medicina, la cirugía se parceló. En obstetricia y ginecología destacaron Francisco Alonso Rubio (1813-1894), fundador de la Sociedad Ginecológica Española, Andrés del Busto López (1832-1899) y Francisco de Cortejarena (1835-1919); en oftalmología, Rafael Cervera Royo (1828-1903), Santiago Delgado Jugo (1830-1878), fundador del Instituto Oftálmico (1872) y Cayetano del Toro Quartiellers (1842-1915); en urología Enrique Suender (1829-1879); en otorrinolaringología Rafael Ariza Espejo (1826-1885), que escribió una Exposición y Juicio Crítico de las Escuelas Histológicas Francesa y Alemana, y en la naciente odontología Cayetano Triviño (1829-1899).

\section{h. Real Academia Nacional de Medicina}

Una Real Cédula de enero de 1831 incluyó la Real Academia Médica Matritense (fundada en 1734) en el plan general de las Reales Academias 


\section{La época de Santiago Ramón y Cajal}

de Medicina y Cirugía del Reino, decretado en agosto de 1830 y que creó distritos académicos, asignando a la de Madrid el de las provincias correspondientes a Castilla la Nueva. El Real Decreto de 28 de abril de 1861, después de oídos los Consejos de Sanidad y de Estado, aprobó un nuevo Reglamento de la Real Academia de Medicina de Madrid, igual en sus fundamentos al de las demás Reales Academias establecidas en Madrid. Tomás Corral y Oña, Marqués de San Gregorio, fue el primer Presidente. Pasados algunos años, el R. D. De 24 de noviembre de 1876 aprobó nuevos Estatutos, según los cuales la Corporación constaba de 48 Académicos de número; D. Francisco Alonso y Rubio fue el primer presidente elegido con los nuevos Estatutos.

La primera de estas polémicas es la que surge entre el vitalismo profesado por gran parte de los académicos y el materialismo defendido por Pedro Mata -académico desde los años 1850s- que pronunció en la Academia, en 1859, un discurso sobre el tema «Hipócrates y las escuelas hipocráticas», positivista y propugnador de las más renovadoras corrientes de la medicina europea. De inmediato surgieron los defensores de un añejo ideario hipocrático que se oponía al programa de Mata centrado en el estudio delas ciencias físico-químicas, la investigación microscópica y el análisis experimental de los fenómenos. La polémica se reavivó cuando Mata publica, en 1860, su Doctrina médico-filosófica española, que fue enconadamente atacada en la Academia. La segunda polémica, menos ruidosa pero también significativa, es contra la homeopatía; una forma de entender la enfermedad y la terapéutica que avanza por entonces por Europa y que a mediado de siglo penetra en España. En 1865 una Real Orden pone en ejecución el establecimiento de cátedra y clínica homeopáticas, de modo provisional y sin carácter académico; la Academia se opone a lo que, en ese momento arraiga en Europa y supone una novedad. Sin embargo, la Academia concede el Premio Rubio, en 1877, a una obra hidrológica en la que el autor, Anastasio García López, hace profesión de su credo homeopático. La tercera polémica es de orden bacteriológico. En 1885, con motivo de la última gran epidemia de cólera en España, Jaime Ferrán idea su método de vacunación anticolérica; la actitud hostil de la Institución frente a la propuesta -la mentalidad etiopatológica no tenía aún sitio en la Academia- perjudica enormemente los esfuerzos de Ferrán. Tres actitudes negativas frente a la introducción de las nuevas mentalidades; pero también comienzan los signos de una recuperación positiva.

Llegado el siglo XX la Academia, al igual que la medicina española, va a vivir lo que se ha denominado «los años de oro del arte de curar his- 
pano: 1900-1936». Los Presidentes de este periodo fueron: Matías Nieto y Serrano, Marqués de Guadalerzas (1900-1902), José Calvo y Martín (1902-1904), Julián Calleja y Sánchez, Conde de Calleja (1902-1914), Carlos María Cortezo y Prieto (1914-1930), Sebastián Recaséns y Girol (1930-1932) y Amalio Gimeno y Cabañas, Conde de Gimeno (1932-1936). El día 30 de junio de 1907, Santiago Ramón y Cajal leía el discurso «Regeneración de los nervios» en el acto de su recepción como numerario en la Real Academia Nacional de Medicina; sucedía en el sillón número 38 a Mariano Salazar y Alegret, Profesor del Hospital de la Princesa, fallecido en septiembre de 1896, cuando apenas había tomado posesión de su medalla.

\section{i. Escuelas libres de Medicina y Cirugía}

Una de las principales preocupaciones de los profesionales que protagonizaron la medicina de mediados del siglo XIX fue la enseñanza de su disciplina. En España, la unión de los estudios médicos y quirúrgicos data de Fernando VII (R.D. de julio de 1827). En 1836 se elaboró un nuevo plan de estudios, inspirado por Pedro Mata y que firmó el ministro Fermín Caballero; en el se ordenaron los estudios de las Facultades de Madrid y Barcelona, buscando más unificar titulaciones que reformar el currículo. Duramente criticado, el Plan Mata fue sustituido en 1845 por el Plan Pidal, que reconocía la capacidad formadora médica de las Universidades de Cádiz, Valencia y Santiago, junto con las de Madrid y Barcelona. Las críticas continuaron y la cambiante política universitaria ochocentista se prolongó hasta 1857, en que se aprobó la reforma universitaria conocida como Ley Moyano. Ley que, en el ámbito médico, unificó de modo definitivo la formación de los profesionales sanitarios y otorgó a todas las Universidades con estudios médicos capacidad para extender títulos de igual validez, hecha la excepción del grado honorífico de doctor que quedó reservado a la Universidad Central de Madrid. El desbarajuste educativo médico es tuvo compartido con el resto de Europa y los pujantes EE.UU, donde, has ta 1859, sólo una escuela médica -en Chicago- había abordado, tímidamente, las reformas apetecidas. Junto con los vaivenes educativos, en 1849, la Ley de Beneficencia ordenaría los establecimientos sanitarios; Ley que sería modificada en 1899, diferenciándose los hospitales, las casas de misericordia, los hospicios y asilos y los manicomios.

Tras la Revolución de 1868, aprovechando el clima de preocupación del momento - heredado de la época isabelina- por el distanciamiento en- 


\section{La época de Santiago Ramón y Cajal}

tre los conocimientos facilitados en las Facultades universitarias de $\mathrm{Me}$ dicina y el nivel de conocimiento exigido por la práctica médica, Ruiz Zorrilla autorizó una absoluta libertad de enseñanza que hizo posible la creación de centros libres de formación médica. Como quedó reseñado líneas atrás, Federico Rubio inauguró, en Sevilla, la primera «Escuela Libre de Medicincor; institución que potenció la especialización quirúrgica, en especial la otorrinolaringología (Ariza), la urología (Enrique Sender) y la ginecología, en la que el mismo Rubio y Eugenio González Gutierrez fueron los verdaderos fundadores de la moderna ginecología española. La especialización en la institución sevillana también afectó a la práctica médica, en especial la neurología.

La experiencia sevillana tuvo un efecto multiplicador con la aparición de escuelas extrauniversitarias, particularmente en los hospitales. En Barcelona surgiría la Academia y Laboratorio de Ciencias Médicas de Cataluña en el Hospital del Sagrado Corazón, inaugurado en el año 1879, que fue cuna de la moderna cirugía española; aquí floreció una importante escuela quirúrgica encabezada por Salvador Cardenal Fernández (1852-1927). Cardenal se destacó por su postura a favor de los métodos antisépticos. Cuando la anestesia se afianzó el cirujano pudo despreocuparse por la rapidez o por el ahorro de las maniobras quirúrgicas; sin embargo, los posibles éxitos de la cirugía se vieron ensombrecidos por las frecuentes y devastadoras infecciones que casi siempre acarreaban la muerte del enfermo. Sólo cuando se descubrió el origen bacteriano del problema y se comprobó la necesidad de proteger el campo operatorio de los gérmenes (antisepsia) -cómo había publicado Lister en 1867- se pudo acceder con éxito a las cavidades del organismo. A la escuela de Cardenal pertenecieron, entre otros, Raventós, Requeséns y Ribas y Ribas.

En Madrid se fundaron tres escuelas: el Instituto Biológico por Rafael Méndez Molina, la Escuela Práctica Libre de Medicina y Cirugía por Pedro González de Velasco y la Escuela Teórico-Práctica de Medicina y Cirugía en el Hospital Provincial de Madrid por Martín de Pedro, Esquerdo, Olavide y Mariano Benavente. Por su parte, en octubre de 1880 se inauguró el Instituto de Terapéutica Operatoria en el Hospital de la Princesa de Madrid; la dirección la ostentó Federico Rubio, que divulgó la obra Institucional a través de la publicación, por él fundada, Revista Iberoamericana de Ciencias Médicas (1899-1936).

En el momento de la fundación de la Sociedad Española de Historia Natural confluyeron -comenta Puig-Samper-dos grupos de naturalistas. Uno, formado por algunos miembros de la Comisión científica del Pacífi- 


\section{Pedro García Barrero y Juan Fernández Santarén}

co (1862-1865); por ejemplo, Miguel Colmeiro, Joaquín González Hidalgo o Marcos Jiménez de la Espada. El segundo, integrado por médicos y naturalistas que se encontraban agrupados en la Sociedad Española de Antropología (fundada en 1865); por ejemplo, Pedro González de Velasco (1815-1882) quién inició la publicación del periódico Anfiteatro anatómico español, Rafael Martínez y Molina (1816-1888), Sandalio de Pereda Martínez (1822-1886) o Juan Vilanova y Piera (1821-1893). Joaquín González de Velasco, a raíz de la Revolución de septiembre de 1868 fundó, en 1873, una Sociedad Anatómica que luego desarrollaría -1875en el Museo Antropológico -sede de la Sociedad Antropológica- con la ayuda de histólogos como Maestre de San Juan o Luis Simarro, y en 1876 una Escuela Libre de Medicina que incluyó entre sus profesores a médicos renovadores como Federico Rubio, quién fundaría el Instituto de Terapéutica Operatoria. Por su parte, Martínez y Molina fundó en su domicilio un Instituto de Biología. A la muerte de Pedro González de Velasco, en 1882, los estudios de Antropología pasaron al Museo de Ciencias Naturales de Madrid, hasta que, en 1910, se creó el Museo de Antropología, Etnografía y Prehistoria. En esta segunda etapa antropológica destacaron Federico Olóriz Aguilera y Manuel Antón Ferrándiz.

Entre las revistas profesionales que se publicaron en la centuria pasada, dos merecen especial atención: el Boletín de Medicina, Cirugía y Farmacia, fundado en 1834, y la Gaceta Médica, que vio la luz en 1845. La fusión de dos de las revistas, en 1854, dio origen a una nueva publicación, El Siglo Médico (Boletín de Medicina y Gaceta Médica) Periódico Oficial de la Real Academia de Medicina de Madrid y de la Sociedad de Socorros Mutuos, cuya edición semanal se mantendría hasta 1936. Un año antes de la fusión indicada surgió La Crónica de los Hospitales, Periódico Ofical de la Facultad de Medicina, Cirugía y Farmacia del General de Madrid; revista que pretendía la revitalización de la Medicina matritense y en cuya introducción, firmada por Martínez Leganés, puede leerse:

"La historia manifiesta que en las épocas de grandeza y de poder politico de las naciones, de hallan también las páginas mas brillantes de su sabiduria y de su literatura. ... Asi es que los hospitales han sido casi siempre el terreno donde la medicina se ha cultivado con mayor éxito y donde los descubrimientos y las mejoras prácticas tuvieron su origen ó recibieron su completa confirmación. ... es alli en donde estos frutos deberian haber sido mas copiosos, pero desgraciadamente no sucedió así... ¿QQué ha sido de la experiencia y de los profundos cono 


\section{La época de Santiago Ramón y Cajal}

cimientos de los Serranos, García Sueltos, Piñeras, Navalcarneros, Alvaros, Blazquez, $y$ otros muchos antiguos y modernos profesores de los hospitales generales de Madrid?. ... Multiplicidad de hechos, juicio recto y severo para apreciarlos, y deducir de ellos legítimas consecuencias, son las dos condiciones necesarias para obtener de la observación aplicaciones provechosas: la primera existe sin duda alguna en el vasto hospital que ha de proporcionar materiales á su CRÓNICA; si los redactores aciertan á proceder con el segundo en sus estudios y trabajos, esta publicación podrá ser un paso muy avanzado para el renacimiento de la medicina españolor.

Tras seis años de cada vez más difícil andadura, en el número de enero de 1858, José Rodríguez Benavides, director de La Crónica junto con Domínguez Pérez Gallego, se dirigía Á Nuestros Lectores (pgs 4-6, tomo VI):

«Las cosas tienen también su pasado, su presente y su futuro, y por consiguiente su vida propia ... Efectivamente, La Crónica de los Hospitales, periódico único, de entre los de su clase, que en España ha sabido sostenerse por especio de cinco años, como lo han observado nuestros apreciados suscritores, á la altura que la ciencia, objeto primario de sus institución le imponía, ha tropezado desde su principio con dificultades mil, y para vencer obstáculos sin cuento ha exigido innumerables sacrificios por parte de sus redactores. Presentado, por los que en 1855 le crearon, el proyecto de fundación al cuerpo facultativo del Hospital general, á fin de que, penetrado del objeto de su misión, le declarase, no tan solo periódico oficial del establecimiento, sino también para que en la empresa tomára la parte que gustase, ó á lo menos permitieran sus individuos que en él constasen sus nombres como redactores, ... (pero) no se prestaron á ser mas que colaboradores. Sin embargo, la fé y entusiasmo con que los fundadores iban á emprender una tarea de la cual habia de reportar beneficios inmensos la ciencia y la humanidad doliente, no les permitió ni aun sospechar que no cooperasen á tan grandioso proyecto aquellos que diariamente disponen de hechos prácticos que, por su importancia y por la frecuencia con que se observan en el Hospital general de Madrid, podian llegar á constituir la verdadera medicina y cirugía españolas. Desgraciadamente no sucedió asi. ... Tales son, ni mas ni menos, las fases por que ha pasado La Crónica de los Hospitales desde su origen. Pero confiamos sobradamente en que, vista la posición franca y esplicita que 
adoptamos, la nueva época que hoy se inaugura, completará el pensamiento que tuvimos desde el principio con respecto á esta publicación ... Madrid 4 de enero de 1858».

Meses después, José Rodríguez Benavides y Domingo Pérez Gallego volvían a dirigirse Á nuestros suscritores (pgs. 553-555, tomo V; 20 de diciembre de 1858) para insistir el en las causas analizadas en su llamamiento anterior, remachando la escasa colaboración del cuerpo facultativo del Hospital y anunciando la fusión de La Crónica de los Hospitales con La España Médica. Desaparecía con ello un periódico exclusivamente científico, «... un género de publicaciones que tanto han contribuido á los adelantos de la ciencia, y por cuya lectura tanta afición se muestra en las naciones extranjeras».

Con todo, fernandinos e isabelinos prepararon la transición hacia el nuevo siglo; paso que realizaron dos generaciones de profesionales. En la primera de ellas destacaron el anatómico Julián Calleja Sánchez (18361913) -autor de un Tratado de Anatomía en cuatro volúmenes-, el patólogo -ya citado- José de Letamendi y el clínico Bartolomé Robert Yarzábal (1842-1902). A poco más de mediados del siglo XIX nacieron los más destacados miembros de la segunda generación -los de la Restauración-; generación que fue designada como la de «los sabios», que reincorporaron a España al terreno de las contribuciones originales, si bien la repercusión en fisiología fue más tardía que en los saberes morfológicos.

En el campo de la anatomía destacaron Federico Olóriz Aguilera (1855-1912), autor de un Manual de Técnica Anatómica, otro Manuel pour L'identification des Délinquents de Madrid y fundador de un Museo Antropológico en donde reunió una importante colección de cráneos; la histología cobró marcada importancia con los discípulos de Maestre de San Juan, Eduardo García Solá (1845-1922), Leopoldo López García (1854-1932) y Luis Simarro Lacabra (1851-1934), antecesor de la obra de Santiago Ramón y Cajal (1852-1934), que dominaría toda la medicina española. La fisiología y la biología contaron con José Gómez Ocaña (18601919) y con Ramón Turró Darder (1854-1926), que realizó numerosas aportaciones a la bacteriología y a la biología; a ellos hay que incorporar los microbiólogos Luis del Rio Lara (1855-1939) y Vicente Llorente Matos (1857-1917).

En la patología general siguió la influencia letamendiana; así, los nombres de Amalio Gimeno Cabañas (1852-1936) y León Corral Maestro (1855-1939), el último de los ochocentistas. Influencia que se mantuvo en la medicina interna con Pedro Esquerdo Esquerdo (1852-1922), Juan Ma- 
riani Larrión (1852-1909), Jacobo López Elizagaray (1856-1934) y Antonio Simonena Zabalegui (1865-1941). Así cómo Federico Rubio forzó el cambio de la mentalidad quirúrgica, la patología general fue renovada por Roberto Novoa Santos (1885-1933); catedrático de Patología general en las Universidades de Santiago y Central representó la ruptura definitiva con la tradición ochocentista letamendiana, siendo el introductor de la interpretación fisiopatológica de la enfermedad (Manual de Patología General). Por su parte, el cambio doctrinal en el terreno clínico lo condujeron Manuel Alonso Sañudo (1856-1912), catedrático en Zaragoza y en Madrid, autor de unas Lecciones de Patología y Clínica Médicas (189193), y Juan Madinaveitia Ortiz de Zárate (1861-1938), fundador de la gastroenterología española, a quienes Gregorio Marañón calificó de maestros de su generación.

Se acentuó la especialización iniciada con la promoción isabelina. A la patología pulmonar, en especial a la tuberculosis, se dedicaron Antonio Espina y Capo (1850-1930), Simón Hergueta Martín (1852-1930) y José Codina Castellví (1867-1934). Espina y Capo fue, según consta en la cubierta de la traducción del citado libro de Bernard Introducción al Estudio de la Medicina Experimental, premio extraordinario de la Facultad de Medicina (curso de 1872), premiado en las oposiciones del Cuerpo de Sanidad Militar, Médico del Hospital General, Inspector de Salubridad pública, Secretario de la Academia Médico-Quirúrgica Española y Socio fundador de la Sociedad española de Terapéutica. En el prólogo de la edición española de la obra de Bernard, Espina y Capo escribió:

"En todas las obras de C. Bernard resalta la idea fundamental de apropiar, modificándoles en los accidentes, el método de investigación de las ciencias fúsico-químicas á las ciencias biológicas. El método analítico y experimental, ayudado del criterio razonador. La alianza de uno y otro fueron los objetivos que le guiaron, porque estaba seguro de que solamente ayudado por estos dos motores, la Medicina saldría de la rutina, dejaría de ser patrimonio del ignorante milagrero, del atrevido empirico ó del confiado vitalista, que con el auxilio de la fe, de la ignorancia ó de la confianza, en la fuerza medicatriz, más que médicos son meros espectadores de la muerte, para llegar á ser, como de derecho le correspondía, la ciencia de la vida y de la muerte, ó mejor dicho la ciencia de la creación, porque crear es vivin.

No cabe duda de que Espina y Capo fue un adelantado a su tiempo. Por su parte, la neurología tuvo en Luis Barraquer Roviralta (1855-1928) 
uno de sus máximos exponentes. La dermatología fue consolidada por Juan Azúa Suárez (1859-1922), destacado participante en la creación de la Sociedad Española de Dermatología y Sifilografía que inició, en 1908, la publicación de las Actas Dermosifilográficas.

La pediatría estuvo impulsada por Francisco Criado Aguilar (18501946) que, aunque la pediatría había recabado la atención de la Escuela Libre de Medicina de Sevilla creada por Federico Rubio, desempeñó la primera Cátedra de pediatría del país, en la Universidad Central; poco después se dotaron las cátedras de Barcelona, Granada y Valencia, estando ocupadas las dos primeras por Andrés Martínez Vargas (18621948) autor de un importante Tratado de Pediatría (1915). La pediatría se afianzó con la creación de centros asistenciales especializados como el Hospital del Niño Jesús en Madrid (1877), donde se editaron las revistas El Hospital de Niños y los Archivos de Medicina y Cirugía de los Niños, el Instituto del Dr. Rubio en Sevilla y una institución similar en Barcelona atendida por Francisco Vidal Solares (1854-1922) o el Sanatorio Marítimo para Niños de Chipiona dirigido por Manuel Tolosa Latour (1857-1919). La farmacología tuvo un claro exponente en Manuel Hurtado de Mendoza, que edito una voluminosa Enciclopedia de Terapéutica (1848). Otros jalones lo representaron Vicente Peset Cervera, titular de la Cátedra valenciana de terapéutica, y Benito Hernando Espinosa (1846-1916), que destacó como farmacólogo clínico.

La cirugía, como la medicina, se polarizó en dos centros universitarios, Barcelona y Madrid. En el primero destacó el ya citado Salvador Cardenal, su discípulo Francisco de Sojo que luego se dedicaría a la otorrinolaringología y Enrique Diego Madrazo (1850-1942); en el segundo, Alejandro San Martín Satrústegui (1847-1908), considerado como una de las grandes figuras de la historia de la cirugía española y, según Marañón, la mejor cabeza -sin contar a Cajal- de la medicina española de su tiempo. San Martín comenzó su actividad profesional como médico rural, consiguiendo en 1874 la Cátedra de terapéutica general de Cádiz y en 1882 la de patología quirúrgica de Madrid; desempeñó los cargos de director del Hospital Clínico y de Ministro de Instrucción Pública. José Ribera Sans (1852-1912) destacó como cirujano torácico y abdominal. Otras figuras que deben recordarse son Juan Creus y Manso (1828-1897) que ocupó cátedras en Granada y en Madrid y dirigió la edición española de la Enciclopedia Internacional de Cirugía de Ashurst, y Enrique Areilza Arregui (1860-1926) en el Santo Hospital Civil de Basurto.

Al igual que las especialidades médicas, la cirugía se desglosó en especialidades cada vez más diferenciadas, debiendo ser recordadas las fi- 


\section{La época de Santiago Ramón y Cajal}

guras de Germán Beriténs, famoso por su errónea interpretación de la pintura del Greco como la consecuencia de una visión astigmática del pintor, Rodolfo del Castillo (1850-1907), José Antonio Barraquer Roviralta (1852-1924), pionero en la cirugía de la catarata y Manuel Márquez, en oftalmología; Eugenio Gutiérrez González (1851-1914), Miguel Ángel Fargas Roca (1858-1916) y Sebastián Recasens Girol (1863-1933), en ginecología; Joaquín Bonet Amigo en obstetricia, en estas fechas separada de la ginecología; Rafael Molla Rodrigo (1856-1930) y Victor Azcárate (1857-1937) en urología, y Ricardo Botey Ducoing (1855-1921) en otorrinolaringología. Por último, en higiene y en política sanitaria destacaron Carlos María Cortezo (1850-1933), Manuel Martín Salazar (1854-1936), Francisco Murillo Palacios (1865-1944) y Luis Comenge Ferrer (1854-1916).

\section{j. La Medicina española en el primer tercio del siglo XX}

¿Y los más próximos? Fueron los médicos nacidos en los años finales del siglo XIX que se incorporaron a su quehacer en la segunda década del XX. La medicina interna inicia una etapa de consolidación, teniendo a su más ilustre representante en Gregorio Marañón y Posadillo (1887-1960), discípulo de Madinaveitia y de Sañudo en Madrid, y de Ehrlich en Alemania. Gregorio Marañón cultivó la endocrinología desde su misma tesis doctoral (La sangre en los estados tiroideos, 1909) y publicó numerosos trabajos clínicos sobre la edad crítica, los estados intersexuales, la evolución de la sexualidad o los síndromes hipofisarios. Marañón, médico del Hospital General de Madrid, miembro de cinco Reales Academias publicó, con la colaboración de Teófilo Hernando Ortega (1881-1976) y con la participación de las figuras más representativas de la medicina de aquel tiempo, el Manual de Medicina Interna (1916-1919), «la primera afirmación -escribió Jiménez Díaz- de nuestras posibilidades de originalidad en el campo de la Medicinco. Años más tarde (1936-1943), el Manual de Diagnóstico Etiológico recogería la labor clínica del autor. Fundó, con Ortega Gasset y Pérez de Ayala el grupo llamado «al servicio de la República»; su obra literaria fue tan prolífica como la científica.

Junto a Marañón, en Madrid, una serie de figuras señeras impulsaron la medicina interna en toda España: Agustín Pedro Pons (18981971), la más relevante figura de la medicina catalana; Fernado Rodríguez Fornos (1883-1951), en Valencia; José Pareja Yébenes (1888-1951), en Granada; Misael Bañuelos (1887-1955), en Valladolid; Miguel Gil Ca- 


\section{Pedro García Barrero y Juan Fernández Santarén}

sares (1873-1933), en Galicia, y Agustín del Cañizo Suárez (1876-1956), en Salamanca y Madrid. En esta última ciudad, dos destacadas personalidades completaron la labor de Marañón, Fernando Enríquez de Salamanca (1890-1966) y Carlos Jiménez Díaz (1898-1967), catedrático precoz de la Universidad de Madrid y fundador del Instituto de Investigaciones Médicas, centro de importante actividad clínica, docente e investigadora. Jiménez Díaz - de formación alemana, políglota, de vas ta cultura y sólida base científica- se destacó en el estudio de las reacciones alérgicas, introduciendo el concepto de labilidad de los mecanismos de reacción celular (disreacción). La farmacología tuvo como maestro de los modernos farmacólogos españoles a Teófilo Hernando, que consiguió, en 1919, con gran visión futurista, que las cátedras de Terapéutica Farmacológica de las Facultades de Medicina estuvieran en conexión con los servicios clínicos hospitalarios; fruto de su dedicación a la gastroenterología fue una Historia del Tenedor.

Entre las especialidades médicas cabe resaltar la tisiología con Manuel Tapia Martínez (1895-1971) -director del Hospital del Rey-y Emiliano Eizaguirre Marquínez (1888-1967), o la cardiología con Luis Calandre Ibáñez (1890-1961). La hematología tuvo un representante destacado en Gustavo Pittaluga Fatorini (1876-1955), que también destacaría en la parasitología. La dermatología contó con José Sánchez Covisa (1881-1859), Enrique Sainz de Aja (1884-1965) y Jaime Peyrí Rocamora (1877-1950). En neurología destacaron Luis Barraquer Roviralta (1853-1928) y Enrique Fernández Sanz (1871-1959). La psiquiatría siguió la polarización de la época de la transición; en Barcelona se desarrolló alrededor de la figura de Emilio Mira, interesado por la psicotecnia y la psicofisiología y a quién, en 1936, se le encargaría la dirección de la Liga Española de Higiene Mental. En Madrid, la obra de Cajal influyó en la orientación neuropsiquiátrica de algunos de sus especialistas, en especial de Gonzalo Rodríguez Lafora (1886-1971). La medicina legal tuvo en Antonio Piga Pascual (1879-1952) un destacado representante. En pediatría destacó Enrique Suñer Ordóñez (1878-1941), especialidad que se complementaría con programas de protección de la infancia, destacando la Escuela Nacional de Puericultura fundada en Madrid, en 1925, bajo la dirección de Enrique Suñer Ordóñez.

La cirugía, como la medicina interna, contó, en el primer tercio del siglo XX, con profesionales de prestigio: José Goyanes Capdevilla (18761964) -fundador del Instituto del Cáncer y de la Asociación Nacional de Cirugía-, León Cardenal Pujals (1878-1960) -autor, entre otras obras, de un Diccionario Terminológico de Ciencias Médicas-, Ricardo Lozano 
(1878-1934), Laureano Olivares Sexmilo (1881-1944), Rafael Argüelles López (1894-1952) y Manuel Gómez Durán (1898-1984). Las especialidades quirúrgicas alcanzaron plena autonomía; la traumatología tuvo, como figuras más destacadas, a Manuel Bastos Ansart (1887-1973), a Mariano Gómez Ulla (1877-1945), ambos médicos militares, y, sobre, todo a Josep Trueta i Raspall (1897-1977). Trueta inició su carrera profesional en Barcelona, exiliándose durante la Guerra Civil -formó parte del Consell Nacional de Cataluña en Francia pasando luego (1939) a Inglaterra-; en Oxford desarrolló una fructífera labor, destacando sus aportaciones al tratamiento de las heridas de guerra y de las fracturas y a la fisiopatología renal postraumática. La revista inglesa British Medical Journal afirmó que el Dr. Trueta «trajo al Reino Unido una diversidad y amplitud de conocimientos y de talento para las investigaciones tanto clínicas como de laboratorio que dieron distinción al Departamento de Ortopedia de Oxford». De vuelta a Barcelona publico «La Estructura del Cuerpo Humano. Estudios sobre el desarrollo y decadencia (Barcelona, 1975), sobre una obra previa (Studies of the Development and Decay of the Human Frame, 1968).

En relación con otras especialidades quirúrgicas, Eugenio Díaz Gómez fue uno de los primeros neurocirujanos españoles. Juan Garrido Les tache y Emilio Roviralta Astoul fueron iniciadores de la cirugía pediátrica; urólogos destacados fueron Leonardo de la Peña Díaz (1875-1957), Pedro Cifuentes Díaz (1881-1960), Salvador Gil Vernet, Ángel Pulido Martín y Benigno Oreja Elósegui. La oftalmología, tal vez la especialidad de mayor prestigio y reconocimiento internacional, estuvo representada por Ignacio Barraquer Barraquer (1884-1965), Hemenegildo Arruga Liro (1886-1972) y Ramón Castroviejo Briones. En otorrinolaringología destacó Antonio García Tapia (1875-1950), y en odontología Florestán Aguilar Rodríguez (1872-1934).

El empeño por la mejora en la preparación de los profesionales cristalizó en la formulación de nuevos programas de enseñanza y nuevas vías de comunicación. Entre los primeros, el que se discutió en el Ateneo de Madrid en el año 1918 con la participación de personalidades del prestigio de Recasens, entonces Decano de la Facultad madrileña de San Carlos, Goyanes Capdevilla, Cortezo y Madinaveitia. El Congreso Nacional de Medicina, celebrado al año siguiente, insistió en la urgente necesidad de reformar la enseñanza médica, solicitando, entre otras medidas, la selección para el ingreso en las Facultades de Medicina e, incluso, la reducción de los centros docentes. El Plan de estudios aprobado en 1928 provocó un amplio eco a la vez que suscitó posturas dispares, aunque el 
sentimiento generalizado seguía resumiéndose en «muchos médicos y muchas Facultades»; tal pensamiento orientó el Plan de estudios firmado por Filiberto Villalobos, en 1935, siendo Ministro de Instrucción Pública y Bellas Artes; el estallido de la contienda civil impidió la aplicación del Plan Villalobos.

En el terreno de las publicaciones, entre las más destacadas nuevas vías de comunicación aparecieron Clínica y Laboratorio (Zaragoza, 1905), la mensual Gaceta Médica Española (Madrid, 1926) en cuyo Consejo editorial participaron Cajal, Marañón, Recasens, Teófilo Hernando, Goyanes y García Tapia, y los Anales de Medicina Interna (1932) a la que estuvieron vinculados Marañón, Jiménez Díaz, Pittaluga, Novoa Santos, Cañizo, García Tapia, Lafora y Teófilo Hernando. No sería hasta después de 1936 cuando comenzaron su andadura las revistas con aceptación internacional: Medicina Española (Valencia), Revista Clínica Española (Madrid) y Medicina Clínica (Barcelona).

$\mathrm{Al}$ igual que los profesionales que encauzaron la transición secular, los médicos que protagonizaron la medicina española ya encauzado el s $\mathrm{XX}$, junto con la preocupación educativa, forzaron un cambio en el sistema sanitario. La iniciativa privada abordó la reforma encaminada a transformar las instituciones benéficas en hospitales modernos. En Madrid, fueron ejemplos representativos el Instituto de Terapéutica Operatoria que Federico Rubio había establecido en el Hospital de la Princesa (Beneficencia); la renovación del Hospital de San Juan de Dios entre 1891 y 1897; el Hospital del Niño Jesús, surgido de la mano de la Asociación Nacional para la Fundación y Sostenimiento de Hospitales de Niños fundada por la Duquesa de Santoña en 1876, abrió sus puertas en 1877 en la calle del Laurel, trasladándose en 1881 a un nuevo edificio; el Instituto Oftálmico, creado por Amadeo de Saboya en 1872, pero que no abrió definitivamente sus puertas hasta 1903. Ya entrado el siglo XX, el Hospital de Santa Cristina, promovido por la Reina María Cristina como escuela de matronas (Casa Salud de Santa Cristina), se construyó de manera intermitente entre los años 1904 y 1924, estando desde entonces sometido a interminables reformas y ampliaciones que aún continúan. Por fin, el primer gran proyecto de un hospital moderno en Madrid fue el Hospital Clínico de San Carlos. La creación de la Ciudad Universitaria, en 1928, permitió abordar la construcción de un hospital universitario propio que permitiera recuperar a la Facultad de Medicina la enseñanza clínica instalada en la «Fábrica del Hospital General». Los arquitectos Manuel Sánchez Arcas y Luis Lacasa junto con el ingeniero Eduardo Torroja abordaron un proyecto que se inició en 1930. Igual significado tu- 
vieron el Santo Hospital Civil de Basurto en Bilbao (1908), la remodelación del Hospital de la Santa Cruz y de San Pablo en Barcelona (1919), y la fundación de la Casa Salud Valdecilla de Santander (1928).

A la par de la iniciativa privada, la acción pública contó con el antecedente de la creación, en 1847, de la Dirección General de Sanidad con carácter consultivo del Consejo de Sanidad, y de la primera Ley de Sanidad que, aprobada en el año 1855, perduraría hasta la Instrucción Ge neral de Sanidad de 1904, inspirada por Carlos María Cortezo. En ese mismo año, la Quinta de la Salud La Alianza, de Barcelona, nació como una mutualidad cooperativista de autónomos, que se supone fue antecesora de la Seguridad Social en España. Seguridad Social que tendría como órgano gestor al Instituto Nacional de Previsión (INP), creado en febrero de 1908. El INP fue esbozado en una ponencia que José Maluquer sometió, en 1903, a la Comisión de Reformas Sociales. El Instituto, adscrito primero al Ministerio de la Gobernación y luego (1920) al de Trabajo, jugaría el papel directivo en la construcción de los hospitales españoles. El primer seguro social establecido con carácter obligatorio lo fue en 1919 con el nombre de Régimen de Retiro Obrero Obligatorio. En 1929 se instauró el Seguro Obligatorio de Maternidad. En 1929 se promulgó la disposición protectora de los accidentes de trabajo en el mar; en 1931, la normativa para los accidentes en la agricultura y, en 1932, la legislación de los accidentes de trabajo en la industria.

La realización de una efectiva acción pública sanitaria exigió la creación de instituciones adecuadas; en ellas destacó el Instituto de Sueroterapia, Vacunación y Bacteriología Alfonso XIII, fundado en octubre de 1899. El Instituto Alfonso XIII reunió dos centros hasta entonces independientes, el Instituto Nacional de Vacunación (1871) y el Instituto de Bacteriología e Higiene; la dirección recayó en Cajal y, luego, en Tello. Una de las orientaciones más originales de la política sanitaria fueron las «luchas» contra padecimientos endémicos con grave incidencia social: en 1905, la tuberculosis; en 1918, las enfermedades veneras; en 1919, el tracoma; en 1920, el paludismo; en 1924, el cáncer; en 1932, las enfermedades reumáticas y cardiovasculares. De 1928 datan las primeras disposiciones respecto a las toxicomanías. Fruto de tales «luchas» fueron el Instituto Nacional de Venereología y el Instituto Oncológico.

Sin embargo, la indudable recuperación de la ciencia española durante la parte final del periodo referido no debe hacer olvidar que no fue realmente superada la instalación anormal del cultivo de la ciencia en nuestra sociedad. El aquietamiento político de la Restauración trajo unas condiciones de tranquilidad y continuidad que resultaron obviamente fa- 
vorables. El conservadurismo ideológico entonces reinante limitó, no obstante, la independencia del pensamiento científico, pero no llegó a hacerla imposible, al menos en lo fundamental, como lo demuestra el hecho de que grupos independientes o disidentes realizaron a contracorriente una labor de gran importancia, cuyos criterios acabarían imponiéndose.

\section{Bibliografía}

BARATAS A (1998): La investigación biológica en la España del primer tercio del siglo XX. En: Sánchez Ron JM (ed) Un Siglo de Ciencia en España. Madrid: Publicaciones de la Residencia de Estudiantes. Pp. 94-113.

BARATAS DÍAZ LA (1997): Introducción y Desarrollo de la Biología Experimental en España entre 1868 y 1936. Madrid: CSIC - Dept. Historia de la Ciencia: Cuadernos Galileo de Historia de la Ciencia ${ }^{\circ} 17$.

Baratas Díaz A (1998): La Estación de Biología Marina de Santander: Ciencia y docencia en el cambio de siglo. En: Ajenjo Bullón X, Suárez Cortina M (eds) Santander, Fin de Siglo. Santander: Universidad de Cantabria. Pp. 333-49.

Baratas Díaz LA (1998): La Biología experimental en la Real Sociedad Española de Historia Natural entre 1871 y 1936. Mem $R$ Soc Esp Hist Nat I (2a ep): 65-79.

Baratas Díaz LA, Fernández Pérez J (1989): Los laboratorios de investigación genética en la Junta para Ampliación de Estudios. Dynamis 9: 225-235.

Baratas Díaz LAA, Gomis Blanco A (1991): La Estación de Biología Marina de Santander: primeros intentos institucionales de introducción de la biología experimental en Es paña. En: Actas V Congr Soc Esp Hist Cien Téc. Murcia: SEHCYT. T II, pp. 884-98.

Baratas Díaz LA, Gomis Blanco A (1998): La Real Sociedad Española de Historia Natural: una historia singular. Arbor CLIX, 625: 109-122.

BARATAS A, FERNÁNDEZ J - eds. (1999): Santiago Ramón y Cajal y sus discípulos en la Real Sociedad Española de Historia Natural. Memorias Real Sociedad Española de Historia Natural, Tomo II, segunda época.

Baratas DíAZ LA, FernáNdez PÉrez J (1992): La enseñanza universitaria de las ciencias naturales durante la restauración y su reforma en los primeros años del siglo XX. Llull 15: 7-34.

CAHo VIU V (1988): La JAE, entre la Institución Libre de Enseñanza y la generación del 14. En: Sánchez Ron (ed): 1907-1987. La Junta para Ampliación de Estudios e Investigaciones Científicas 80 Años Después. Vol II. Madrid: Consejo Superior de Investigaciones Científicas. Pp. 3-26.

CASAdo S (1998): Gea, flora y fauna. En: Sánchez Ron JM (ed) Un Siglo de Ciencia en España. Madrid: Publicaciones de la Residencia de Estudiantes. Pp. 74-93.

Cazurro M, Arias Encobet J (1921): Ignacio Bolívar y las Ciencias Naturales en España. Madrid: Imprenta Clásica Española (Edición facsímil por el CSIC, Madrid, 1988).

COMPTE SART A (1988): La JAE y la investigación zoológica en España. En: Sánchez Ron (ed): 1907-1987. La Junta para Ampliación de Estudios e Investigaciones Científicas 80 Años Después. Vol II. Madrid: Consejo Superior de Investigaciones Científicas. Pp. 429-64.

FERrater Mora J (1994): Diccionario de Filosofía. Barcelona: Editorial Ariel SA. Ed Revisada. Tomo III. 


\section{La época de Santiago Ramón y Cajal}

GARCÍA BARRENo P (1998): La medicina española hacia su modernización. En: Sánchez Ron JM (ed) Un Siglo de Ciencia en España. Madrid: Publicaciones de la Residencia de Estudiantes. Pp. 140-157.

García Barreno P, Durán A, Ríos S, Martín Municio A (1992): Real Academia de Ciencias Exactas, Físicas y Naturales. En: Instituto de España (ed) Las Reales Academias del Instituto de España. Madrid: Alianza Editorial. Pp. 235-89.

García Sansegundo M (1914): El Ateneo Científico, Literario y Artístico de Madrid. Madrid: Establecimiento Tipográfico de El Liberal.

GARcía Sierra P (1993): La evolución filosófica e ideológica de la Asociación Española para el Progreso de las Ciencias (1908-1979). El Basilisco, 15 (2 época): 49-81.

Gomis A, Josa J, Pelayo F, Fernández J (1988): Análisis de las publicaciones de Ciencias Biológicas de la JAE. En: Sánchez Ron (ed): 1907-1987. La Junta para Ampliación de Estudios e Investigaciones Científicas 80 Años Después. Vol II. Madrid: Consejo Superior de Investigaciones Científicas. Pp. 381-399.

Gomis Blanco A (1998): Desarrollo institucional de la Real Sociedad Española de Historia Natural. Mem $R$ Soc Esp Hist Nat I (2a ep): 5-46.

GonzÁlez Bueno A, Gallardo T (1988): Los estudios botánicos en la JAE. En: Sánchez Ron (ed): 1907-1987. La Junta para Ampliación de Estudios e Investigaciones Científicas 80 Años Después. Vol II. Madrid: Consejo Superior de Investigaciones Científicas. Pp 465-84.

GuerRA F (1989): Historia de la Medicina. Vol II: Medicina del Positivismo. Madrid: Ediciones Norma SA.

JMÉ́NEZ A (1971): La Universidad en ruinas. En: Historia de la Universidad Española (Tercera parte: ocaso y restauración). Madrid: El Libro de Bolsillo [335] Alianza Editorial SA. Pp. 290-311.

JMÉ́NEZ-LANDI MARTínez A (1973): La Institución Libre de Enseñanza y su Ambiente. Los origenes. Madrid: Taurus Ediciones SA.

JIMÉNEZ-LANDI MARTÍNEZ A (1996): La Institución Libre de Enseñanza y su Ambiente. Vol I: Los orígenes de la Institución; vol II: Periodo parauniversitario; vol III: Periodo escolar 1881-1907; vol IV: Perido de expansión influyente. Madrid: Editorial Complutense SA.

MAdARIAGA DE LA CAMPA B (1972): Augusto González de Linares y el Estudio del Mar. Ensayo crítico y biográfico de un naturalista. Santander: Instituto de Estudios Marítimos y Pesqueros Juan de la Cosa.

MADARIAGA DE LA CAMPA B (1986): De la Estación de Biología Marina al Laboratorio Oceanográfico de Santander. Noticias históricas de un Centenario (1886-1986). Santander: Artes Gráficas Resma.

MADARIAGa DE LA CAMPA B (1988): Augusto González de Linares y el grupo institucionista de Santander. Bol Institución Libre Enseñanza 6: 83-103.

MATILLA V (1992): La Real Academia Nacional de Medicina. En: Instituto de España (ed) Las Reales Academias del Instituto de España. Madrid: Alianza Editorial. Pp. 339-83.

MORENO GONZÁlEZ A (1989): Aportaciones de la Junta a la reforma del sistema educativo español. En: Sánchez Ron (ed): 1907-1987. La Junta para Ampliación de Estudios e Investigaciones Científicas 80 Años Después. Vol II. Madrid: Consejo Superior de Investigaciones Científicas. Pp. 161-84.

Río HoRTEGA P DEL (1986): El Maestro y yo (Edición a cargo de Alberto Sánchez Álvarez.Insúa). Madrid: CSIC.

SÁNCHEZ Ron JM (1988): La Junta de Ampliación de Estudios e Investigaciones Científicas ochenta años después. En: Sánchez Ron (ed): 1907-1987. La Junta para Amplia- 
ción de Estudios e Investigaciones Científicas 80 Años Después. Vol I. Madrid: Consejo Superior de Investigaciones Científicas. Pp. 1-61.

SÁNCHEZ RoN JM (1999): Cincel, Martillo y Piedra. Historia de la Ciencia en España (siglos $X I X$ y $X X)$. Madrid: Grupo Santillana de Ediciones SA (Taurus - pensamiento).

ToRroJA JM (1938): La Asociación Española para el Progreso de las Ciencias en su Primera Época (1908-1936). Asociación Española para el Progreso de las Ciencias: XV Congreso. Santander 19-25 agosto. Pp. 7-20.

VALDERAS JM (1988): La genética en la JAE. Antonio de Zulueta y Escolano (1885-1971). En: Sánchez Ron (ed): 1907-1987. La Junta para Ampliación de Estudios e Investigaciones Científicas 80 Años Después. Vol II. Madrid: Consejo Superior de Investigaciones Científicas. Pp. 401-28.

VillaCoRTa BAÑos F (1985): El Ateneo Cientifico, Literario y Artístico de Madrid (18851912). Madrid: CSIC-Centro de Estudios Históricos.

\section{Nota}

${ }^{1}$ El tema del presente trabajo fue presentado a los Simposios I y II que, sobre «Ciencia y Técnica en España de 1898 a 1945: Cabrera, Cajal, Torres Quevedo", tuvieron lugar en Lanzarote, durante los meses de agostó de los años 1999 y 200 . Agradezco a los editores de aquellas actividades $-F$. González de Posada, F. A. González Redondo y D. Trujilo Jacinto del Castillo- las facilidades y el apoyo recibido. 